UNIVERSIDADE DE BRASÍLIA

INSTITUTO DE CIÊNCIAS BIOLÓGICAS

DEPARTAMENTO DE FITOPATOLOGIA

PROGRAMA DE PÓS-GRADUAÇÃO EM FITOPATOLOGIA

\title{
O COMPLEXO DA MANCHA-BACTERIANA EM Capsicum \\ NO BRASIL: ESPÉCIES E SUA SENSIBILIDADE AO COBRE
}

RAYANE DOS SANTOS LIMA

Brasília - DF 


\title{
RAYANE DOS SANTOS LIMA
}

\section{O COMPLEXO DA MANCHA-BACTERIANA EM Capsicum NO BRASIL: ESPÉCIES E SUA SENSIBILIDADE AO COBRE}

\begin{abstract}
Dissertação apresentada à Universidade de Brasília como requisito parcial para a obtenção do título de Mestre em Fitopatologia pelo Programa de Pós Graduação em Fitopatologia
\end{abstract}

\section{Orientadora}

Alice Maria Quezado Duval, DSc.

\section{BRASÍLIA}

DISTRITO FEDERAL - BRASIL 


\section{FICHA CATALOGRÁFICA}

Lima, Rayane dos Santos

O complexo da mancha-bacteriana em Capsicum no Brasil: espécies de Xanthomonas e sua sensibilidade ao cobre. Orientação: Alice Maria Quezado Duval. 2015. 87p.

Dissertação de mestrado. Programa de Pós-Graduação em Fitopatologia, Universidade de Brasília, Brasília.

1 - Pimentão. 2 - Pimenta. 3 - Xanthomonas euvesicatoria. 4 - X. gardneri. 5 - X. perforans.

\section{REFERÊNCIA BIBLIOGRÁFICA}

Lima, R. S. 2015. O complexo da mancha-bacteriana em Capsicum no Brasil: espécies de Xanthomonas e sua sensibilidade ao cobre. Brasília, Universidade de Brasília, Dissertação de mestrado. 87p.

\section{CESSÃO DE DIREITOS}

NOME DO AUTOR: Rayane dos Santos Lima

TÍTULO DA DISSERTAÇÃO DE MESTRADO: O complexo da mancha-bacteriana em Capsicum no Brasil: espécies de Xanthomonas e sua sensibilidade ao cobre GRAU: MESTRE ANO: 2015 
"Há um casamento que ainda não foi feito no Brasil: entre o saber acadêmico e o saber popular. O saber popular nasce da experiência sofrida, dos mil jeitos de sobreviver com poucos recursos. O saber acadêmico nasce do estudo, bebendo de muitas fontes. Quando esses saberes se unirem, seremos invencíveis." 
À minha querida mãe, por todo amor, carinho, respeito, incentivo e confiança durante todos os momentos de minha vida.

Ofereço.

Aos meus irmãos Rodrigo e Rogério, aos meus avós Sebastião Olímpio (in memorian) $e$ Margarida Irias e ao meu namorado Thiago Rodrigues, pelo amor e apoio em todos os momentos de realização deste mestrado.

Com todo carinho,

Dedico. 


\section{AGRADECIMENTOS}

- À Embrapa Hortaliças pela oportunidade de trabalho no laboratório de Fitopatologia.

- Aos professores do Departamento de Fitopatologia da Universidade de Brasília e aos funcionários.

- Ao CNPq pela bolsa de estudos.

- À Deus, que, de forma simples e grandiosa, expressa seu imenso amor, guiando-me e fortalecendo-me em todos os momentos.

- À Nossa Senhora, por olhar e me conduzir no dia a dia.

- À minha mãe Maria Florita, meus irmãos Rodrigo dos Santos e Rogério dos Santos e minha avó Margarida Irias, pelo apoio, amor e carinho em todos os momentos. Obrigada, vocês são a razão da minha vida.

- Ao meu avô Sebastião Olimpio (in memoriam), agradeço pelo amor e principalmente por todo carinho de avô e de pai a mim concedidos.

- Ao meu namorado Thiago Rodrigues, pelo companheirismo e todo amor a mim dedicado. Dedico também esta vitória a você.

- Aos meus sobrinhos Pedro Henrique, Paulo Henrique, João Henrique e Bianca, pelo amor e carinho. Titia os ama.

- Aos meus tios Antônio Olímpio, Joaquim Olímpio, José Olimpio, Livanir dos Santos, Manoel Divino, Maria Rosilda e Ronaldo Olimpio. Muito obrigada por todo apoio.

- As minhas primas Daniela e Luana, que sempre estiveram ao meu lado me dando forças nos momentos de tristeza.

- A todos da minha família, que sempre estiveram me apoiando e torcendo por mim.

- À Dra. Alice Quezado, pela orientação e amizade. Obrigada pelos ensinamentos e pela oportunidade de trabalho e crescimento profissional. 
- Aos amigos do laboratório de Fitopatologia da Embrapa Hortaliças, Amanda, Celma, Fabiana, Frederick, Janderson, Jefferson, Luana Maria, Luiz Henrique e Michelle. Agradeço pela amizade e ajuda em todos os momentos e principalmente por compartilharem tantas alegrias em minha vida.

- Aos amigos de pós-graduação do meu semestre Juliana, Josiane e Rafaela. Obrigada pela amizade, companheirismo e trocas de experiências.

- Aos amigos Cléia, Edivânio, Elenice, Josineide, Maurício e Marcella obrigada por sempre acreditar no meu potencial e principalmente pelos conselhos, incentivos e amizade.

- A todos aqueles que, de alguma forma, contribuíram para a realização deste trabalho. 
Trabalho realizado junto ao Departamento de Fitopatologia do Instituto de Ciências Biológicas da Universidade de Brasília, sob orientação da Doutora Alice Maria Quezado Duval, com apoio do Conselho Nacional de Desenvolvimento Científico e TecnológicoCNPq.

\title{
O COMPLEXO DA MANCHA-BACTERIANA EM Capsicum NO BRASIL: ESPÉCIES DE Xanthomonas E SUA SENSIBILIDADE AO COBRE
}

\author{
RAYANE DOS SANTOS LIMA
}

DISSERTAÇÃO APROVADA em ______ por:
Pesquisadora, Doutora Alice Maria Quezado Duval (Embrapa Hortaliças)
Orientadora

\footnotetext{
Professora, Doutora Marisa Álvares da Silva Velloso Ferreira (Universidade de Brasília) Examinadora Interna
}
Professor, Ph.D. Carlos Alberto Lopes (Embrapa Hortaliças)
Examinador Externo
Professor, Ph.D. Adalberto Corrêa Café-Filho (Universidade de Brasília) Suplente

\section{BRASÍLIA}

DISTRITO FEDERAL - BRASIL 


\section{SUMÁRIO}

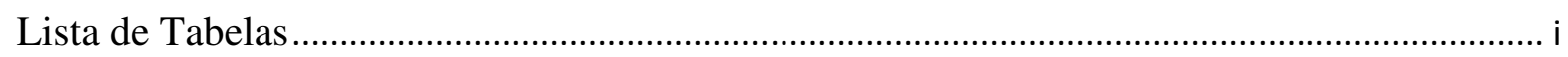

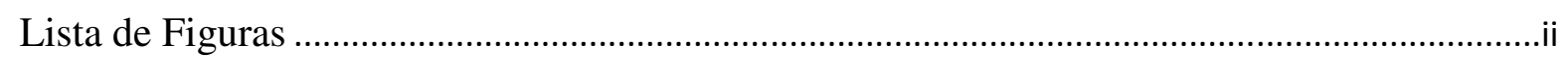

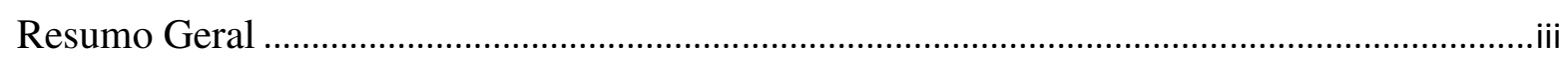

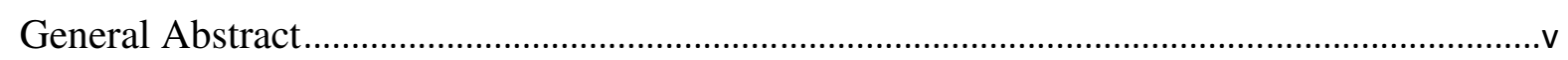

Introdução Geral e Revisão de Literatura .................................................................. 1

1. A cultura do pimentão e da pimenta.................................................................................... 1

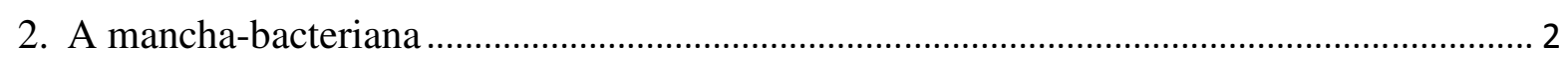

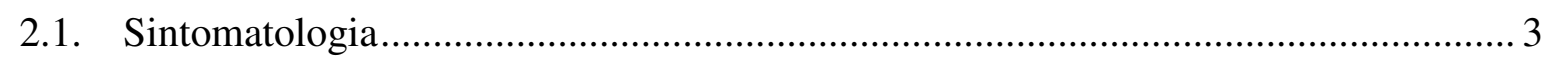

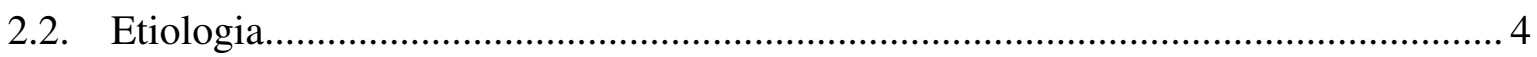

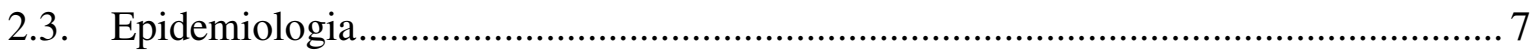

2.4. Interação Xanthomonas spp. - Capsicum .................................................................. 8

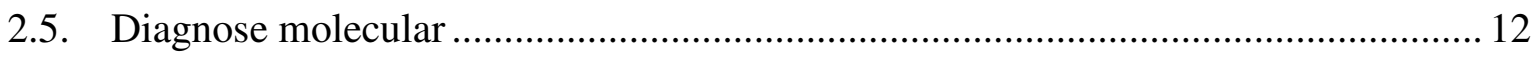

2.6. Controle químico e resistência ao cobre .................................................................. 14

2.7. Resistência de Capsicum à mancha-bacteriana ...................................................... 16

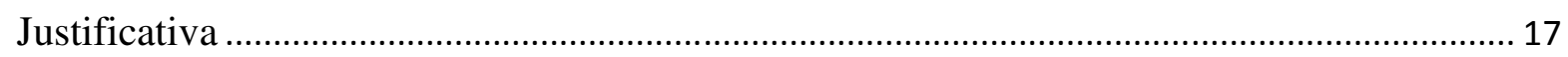

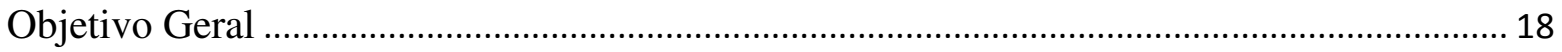

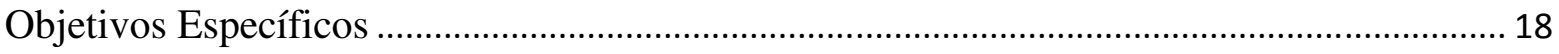

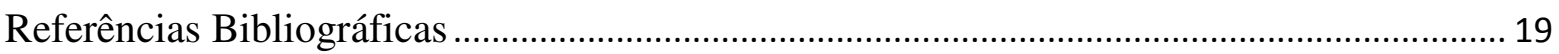

CAPÍTULO 1.Espécies e raças de Xanthomonas associadas à mancha-bacteriana em

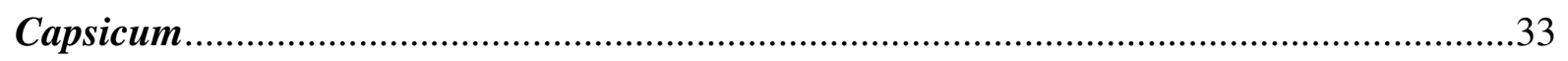

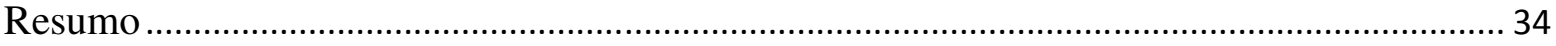

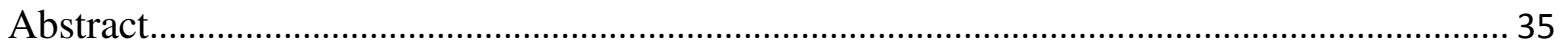

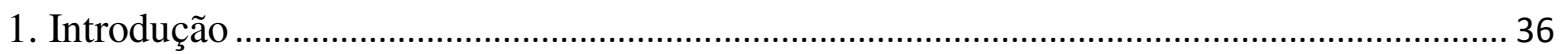

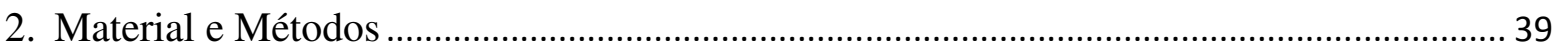

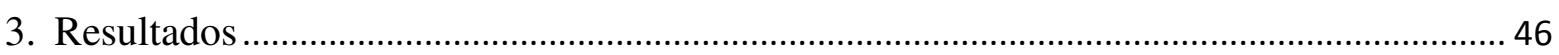

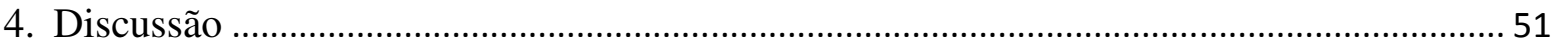

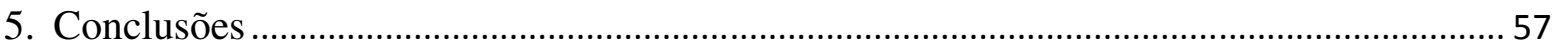

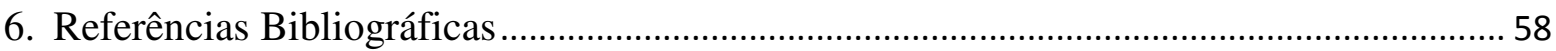


CAPÍTULO 2. Sensibilidade ao cobre de isolados de Xanthomonas spp. associadas à

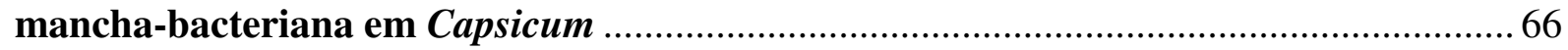

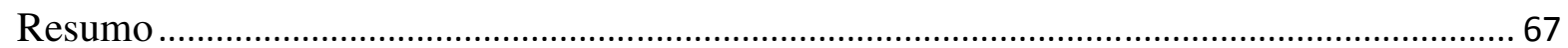

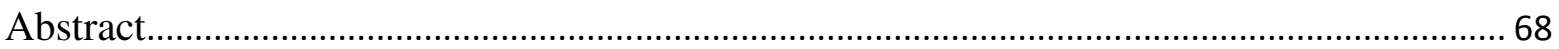

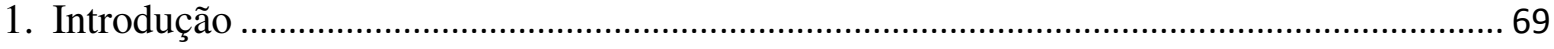

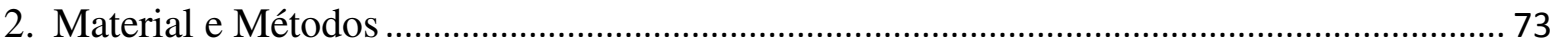

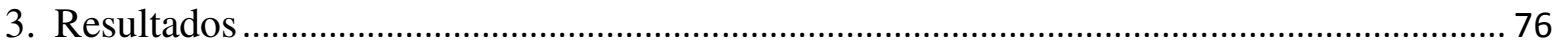

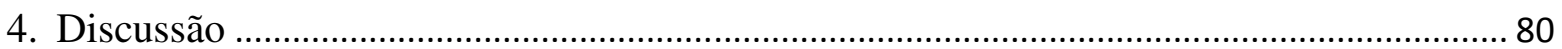

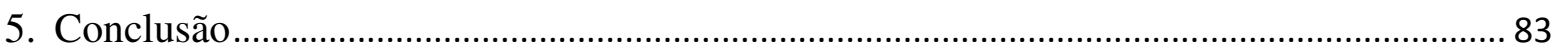

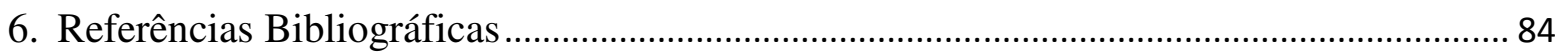




\section{LISTA DE TABELAS}

\section{INTRODUÇÃO GERAL E REVISÃO DE LITERATURA}

Tabela 1. Histórico da classificação de Xanthomonas patogênicas a pimentão e tomate.

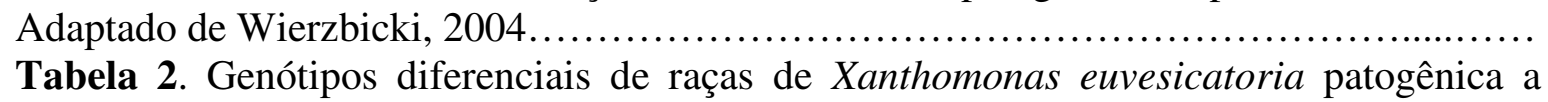
Capsicum e genes de resistência identificados. Adaptado de Wierzbichi, $2004 . .$.

Tabela 3. Genes de resistência à mancha-bacteriana em acessos de Capsicum e efetores bacterianos que interagem com eles. Adaptado de Stall et al. (2009).

\section{CAPÍTULO 1}

Tabela 1. Reação de genótipos diferenciadores às 11 raças de Xanthomonas euvesicatoria associadas à mancha-bacteriana em Capsicum e genes avr e Hrp bacterianos, associados ao gene de resistência ao patógeno. (Adaptado de Jones, 1998). ...

Tabela 2. Hospedeira, cultivar, ano, local de coleta e identificação dos isolados brasileiros da coleção de Xanthomonas associadas ao gênero Capsicum spp. do Laboratório de Fitopatologia da Embrapa Hortaliças.

\section{CAPÍTULO 2}

Tabela 1. Lista de isolados da coleção (1982 a 2014) de Xanthomonas associadas a Capsicum do Laboratório de Fitopatologia da Embrapa Hortaliças, Brasília, DF.

Tabela 2. Sensibilidade ao cobre de isolados de Xanthomonas spp. causadores da manchabacteriana em Capsicum. 


\section{LISTA DE FIGURAS}

\section{INTRODUÇÃO GERAL E REVISÃO DE LITERATURA}

Figura 1. Sintomas de mancha-bacteriana em Capsicum. A- Lesões necróticas nas folhas; B e C- Lesões necróticas nos frutos de pimenta (Capsicum chinense) e pimentão (Capsicum annuum); D- Plantas com desfolha intensa. Fotos: Alice Quezado............................. Figura 2. Colônias bacterianas amarelas típicas das espécies de Xanthomonas causadoras da mancha-bacteriana no gênero Capsicum, em meio ágar nutriente. .......................

\section{CAPÍTULO 1}

Figura 1. Inoculação por infiltração em folhas de pimentão. B- Reação de hipersensibilidade a Xanthomonas euvesicatoria em folha de pimentão por um isolado incompatível.

Figura 2. Sintomas da mancha-bacteriana em folhas de pimentão. A e B- Perfurações causadas pela espécie Xanthomonas perforans. Foto: Alice Quezado........................ Figura. 3. Perfil BOX-PCR de isolados de Xanthomonas spp causadoras de manchabacteriana em plantas do gênero Capsicum em gel de agarose (1,5\%) (A e B) . Xe, Xv, Xp e Xg são isolados de referência de X. euvesicatoria (IBSBF 2363), X. vesicatoria (IBSBF 2364) X. perforans (IBSBF 2370) e X. gardneri (IBSBF 2373), respectivamente. $\mathrm{M}=$ marcador $1 \mathrm{~kb}$ plus DNA ladder (A e B). A- Isolados caracterizados como $X$.gardneri: de 1 a 4; B - Isolados caracterizados como X. euvesicatoria: 1 a 9.

Figura 4. Eletroforese em gel de agarose $(1,5 \%)$, dos produtos de PCR obtidos com iniciadores específicos. A- Fragmentos correspondenetes ao iniciador específico de Xanthomonas gardneri (154pb); B- Fragmentos correspondentes ao iniciador específico de $X$. euvesicatoria (173pb); C- Fragmentos de 680pb correspondentes ao gene avrRxv, relacionado a hipersensibilidade em tomateiro e característico da espécie Xanthomonas euvesicatoria. $\mathrm{M}=$ marcador $1 \mathrm{~kb}$ plus DNA ladder. $\mathrm{CP}=$ controle positivo da espécie. $\mathrm{CN}=$

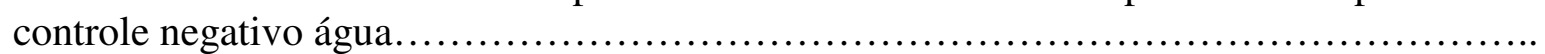

Figura 5. Distribuição das espécies dos 76 isolados de Xanthomonas spp. coletados em onze estados brasileiros mais o Distrito Federal.

Figura 6. Distribuição das raças dos 67 isolados da espécie Xanthomonas euvesicatoria coletados em doze estados brasileiros mais o Distrito Federal...............................

\section{CAPÍTULO 2}

Figura 1. Reação ao cobre de isolados de Xanthomonas causadores da mancha-bacteriana em Capsicum. Sensibilidade foi determinada pelo crescimento confluente em meio CYE. A: CYE sem de sulfato de cobre. B: $50 \mu \mathrm{g} / \mathrm{mL}$ de sulfato de cobre. C: $100 \mu \mathrm{g} / \mathrm{mL}$ de

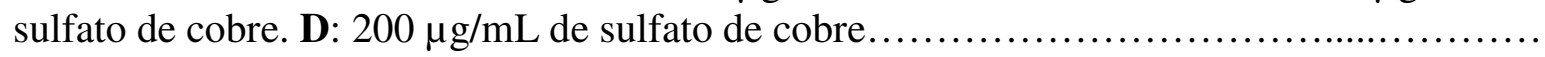
Figura 2. Insensibilidade ao cobre de isolados de Xanthomonas associadas à manchabacteriana em Capsicum. Sensibilidade foi determinada pelo crescimento confluente em meio CYE suplementado com 50; 100 e $200 \mu \mathrm{g} / \mathrm{mL}$ de sulfato de cobre........................................................................

Figura 3. Porcentagem de isolados insensíveis às diferentes concentrações de cobre de acordo com a região em que foram coletados.

Figura 4. Porcentagem de isolados insensíveis às diferentes concentrações de cobre de acordo com a época em que foi isolado 


\section{RESUMO GERAL}

LIMA, Rayane dos Santos. O complexo da mancha-bacteriana em Capsicum no Brasil: espécies de Xanthomonas e sua sensibilidade ao cobre. 2015. 87p. Mestrado em Fitopatologia - Universidade de Brasília, Brasília, DF.

O Brasil possui ampla diversidade de pimentas e pimentões, destacando-se quatro espécies domesticadas: Capsicum annuum, C. baccatum, C. chinense e $C$. frutescens. Dentre as doenças que acometem esse grupo, a mancha-bacteriana está entre as mais importantes em cultivos a campo aberto. Inicialmente, apenas as espécies X. euvesicatoria e X. gardneri estariam associadas ao gênero Capsicum, porém, recentemente foi constatada a ocorrência de $X$. perforans na Flórida e X. vesicatoria na Macedônia e na Bulgária associada ao pimentão. Xanthomonas euvesicatoria apresenta especificidade em nível de raças fisiológicas, com 11 raças relatadas até o presente, o que contribui para a dificuldade no controle da doença. $\mathrm{O}$ controle químico da mancha-bacteriana tem sido realizado com produtos à base de cobre. Considerando a pouca informação sobre a presença dessas raças em lavouras de Capsicum no Brasil, no presente trabalho foram identificados 76 isolados de Xanthomonas obtidos de amostras de folhas sintomáticas de pimentas coletadas, entre os anos 1982 e 2014, nos estados de Goiás, Ceará, Bahia, Sergipe, Pernambuco, Roraima, Pará, Amazonas, Minas Gerais, Espírito Santo e São Paulo e do Distrito Federal. Para tanto, utilizou-se PCR com iniciadores específicos e a análise comparativa com isolados de referência dos perfis obtidos por BOXPCR. Setenta e um isolados foram identificados como X. euvesicatoria. Quatro isolados, coletados na região Sudeste, foram X. gardneri e um isolado do Ceará foi X. perforans, sendo este o primeiro relato da ocorrência natural dessas espécies em campos de produção de pimentão no país. Os isolados de $X$. euvesicatoria foram ainda caracterizados quanto à raça pela reação provocada nas linhagens diferenciais quase-isogênicas ECW, ECW-10R, ECW20R e ECW-30R, as três últimas contendo os genes de resistência $B s 1, B s 2$ e $B s 3$, respectivamente. A ocorrência da reação de hipersensibilidade (RH) foi observada com 12, 24 e 36 horas após a infiltração, respectivamente para os três genótipos resistentes. Os isolados foram das seguintes raças: $0,2,5,1$ ou 7, 3 ou 8, 4 ou 9, 6 ou 10. Isolados das raças 1 ou 7, 3 e 8, 4 e 9 ou 6 e 10 ainda não puderam ser definidos pela não utilização do PI-234047, um acesso de $C$. pubescens ainda não presente no banco de germoplasma de Capsicum da Embrapa Hortaliças. Avaliou-se também a sensibilidade in vitro de 73 isolados ao cobre. Utilizou-se sulfato de cobre em meio CYE, nas concentrações de 0, 50, 100 e 200 ppm $(\mu \mathrm{g} / \mathrm{mL})$, considerando resistentes os isolados que apresentaram crescimento confluente em 
três repetições. No controle (ausência de cobre) houve crescimento de 100\% dos isolados. Nas concentrações de 50 e $100 \mu \mathrm{g} / \mathrm{mL}, 74 \%$ e $63 \%$ dos isolados foram insensíveis, respectivamente. Apenas sete isolados (10\%) foram insensíveis a maior concentração do produto $(200 \mu \mathrm{g} / \mathrm{mL})$. O esclarecimento da frequência de ocorrência de espécies e raças associadas à mancha-bacteriana do pimentão; a elucidação dos níveis de sensibilidade que esses isolados apresentam ao cobre são informações de fundamental importância para a adoção de estratégias de manejo eficientes da mancha-bacteriana das culturas de pimentão e pimentas no país.

Palavras-chave: Xanthomonas euvesicatoria, X. perforans, X. gardneri, raças, PCR, pimentas, pimentões, controle químico

Orientadora - Alice Maria Quezado Duval- Embrapa Hortaliças 


\section{GENERAL ABSTRACT}

LIMA, Rayane dos Santos. Bacterial spot complex on Capsicum in Brazil: Xanthomonas species and their copper sensibility. 2015. 87p. Master in Phytopahology University of Brasília, Brasília, DF, Brazil.

Great diversity of peppers and bell peppers is observed in Brazil. Four domesticated species of Capsicum can be highlighted: Capsicum annuum, C. baccatum, C. frutescens and $C$. chinense. Bacterial spot is one of the most relevant disease of the genera in open field cultivation systems. Up to recently, the only species associated with the genus Capsicum were X. euvesicatoria and X. gardneri. . However, the occurrence of X. perforans was reported in Florida, and of X. vesicatoria in Macedonia and Bulgaria. Xanthomonas euvesicatoria specialized as physiological races, and 11 races have been reported up to date, which contributes to the difficulty of disease control. Chemical control of the disease has been made with copper-based products. Considering the little information about the presence of these races in Capsicum crops in Brazil, in the present study seventy-six Xanthomonas isolates from symptomatic peppers leaf samples were collected between the years 1982 to 2014 in the states of Goiás, Ceará, Bahia, Sergipe, Pernambuco, Roraima, Pará, Amazonas, Minas Gerais, Espírito Santo and São Paulo, as well as in and the Federal District; had their species identified. These isolates were characterized using specific primers and PCR-BOX. Seventyone isolates were identified as X. euvesicatoria. Four isolates collected in the Southeast, were $X$. gardneri and one isolate of Ceará was $X$. perforans. In order to determine the races of $X$. euvesicatoria isolates, near isogenic lines ECW-10R, ECW-30R, ECW-20R and ECW, which contain the resistance genes $B s 1, B s 2$ and $B s 3$, respectively, were used. The presence or absence of a hypersensitive response (HR) was observed 12, 24 and 36 hours after inoculation, respectively for the three resistant genotypes. The isolates were of the following races: $0,2,5,7$ or $1,3,8,9$ or 4,6 or 10 . Isolates of races 1 or 7,3 and 8,4 and 9 or 6 and 10 were not yet possible to define not using the PI-234047, since Embrapa Hortaliças does not have $C$. pubescens in its Capsicum germplasm bank. Copper in vitro sensitivity of 71 isolates was also evaluated. Copper sulfate CYE medium at concentrations of 0, 50, 100 and $200 \mathrm{ppm}$ $(\mu \mathrm{g} / \mathrm{mL})$ was used. Those isolates that showed confluent growth after three repetitions were considered insensitive. One hundred percent of the isolates growed on the check-control (no copper amended to the medium). With concentration of 50 and $100 \mu \mathrm{g} / \mathrm{mL}, 74 \%$ and $63 \%$ of the isolates were insensitive, respectively. Only seven isolates (10\%) were insensitive to 
higher product concentration $(200 \mu \mathrm{g} / \mathrm{mL})$. Insights on the frequency of occurrence of species and races associated with pepper bacterial spot; elucidation of insensitivity levels to copper of the Brazilian isolates are information of fundamental importance for the adoption of efficient management strategies to bacterial spot on Capsicum crops in the country.

Keywords: Xanthomonas euvesicatoria, X. perforans, X. gardneri, races, PCR, peppers, bell peppers, chemical control 


\section{INTRODUÇÃO GERAL E REVISÃO DE LITERATURA}

\section{A cultura do pimentão e da pimenta}

As pimentas e os pimentões pertencem à família Solanaceae, gênero Capsicum. Este gênero possui de 20-25 espécies, que podem ser divididas com base no processo de domesticação. As espécies domesticadas são: Capsicum annuum, C. pubescens, C. frutescens, C. chinense e C. baccatum (IBPGR, 1983; Mongkolporn e Taylor, 2011). O Brasil destaca-se por possuir ampla diversidade em todas as categorias e contempla quatro espécies domesticadas: Capsicum annuum, Capsicum baccatum, Capsicum chinense e Capsicum frutescens (Oliveira, 2000; Ribeiro et al., 2006; Carvalho et al., 2008).

As pimentas e os pimentões foram, possivelmente, os primeiros aditivos alimentares utilizados pelas civilizações antigas do México e América do Sul, sendo usados para dar aroma, cor, sabor e preservar os alimentos (Pikersgill, 1997). Esses frutos estão presentes na culinária da maioria dos países, sendo amplamente utilizados como condimento, corante e hortaliças. Os tipos pungentes são usados frescos, verdes ou maduros, curtidos, secos ou industrializados. Os tipos não-pungentes são amplamente utilizados, verdes ou maduros, como hortaliças, sendo, também, consumidos frescos, curtidos, assados, cozidos, secos, em pó ou em conserva (Viñals, 1996; Pickersgill, 1997; Filgueira, 2008; Moreira et al., 2006). Os frutos de Capsicum contêm as vitaminas A, E, B1, B2 e principalmente, vitamina C. Possuem, ainda, proteínas, glicídios, lipídios, minerais, água e fibras (Geleta e Labuschagne, 2004). Quando consumidos em quantidades adequadas, podem assegurar a manutenção das funções vitais do organismo, suprindo as necessidades de energia, de elaboração e manutenção dos tecidos e de equilíbrio biológico. Os frutos possuem pigmentos, como os carotenoides, responsáveis pela sua coloração e pelo corante vermelho da páprica (IBPGR, 1983; Carvalho et al., 2010). 
Além de uso culinário, pimentas e pimentões estão sendo estudados por áreas relacionadas à medicina e à farmácia, por sua ação conservante, antimicrobiana, para fins terapêuticos e na prevenção de doenças. Carvalho et al. (2010) estudaram a atividade antimicrobiana in vitro de pimentas e pimentões sobre quatro bactérias que infectam e intoxicam alimentos, onde quatro genótipos estudados apresentaram atividade de inibição e inativação seletiva sobre salmonelas, coliformes fecais, enterococos e estafilococos.

No Brasil, cultivam-se pimentas do gênero Capsicum em praticamente todos os estados da federação, mas os principais produtores são: Minas Gerais, São Paulo, Goiás, Ceará e Rio Grande do Sul (Ribeiro et al., 2008).

\section{A mancha-bacteriana}

A mancha-bacteriana é uma das doenças mais comuns dos cultivos de pimentão e pimentas no Brasil a campo aberto e em épocas quentes e chuvosas. A doença pode ser transmitida pela semente e disseminar-se à longa distância (Bashan et al., 1985). Nos casos em que apenas pequena parte da plantação for afetada, essa pode se propagar para as plantas sadias por meio de chuva associada a ventos fortes (Oliveira, 2000).

Dados apresentados pela European and Mediterranean Plant Protection Organization - EPPO (organização intergovernamental responsável pela cooperação europeia em cuidados com culturas comerciais, 2003) ressalta o tomate e o pimentão como principais hospedeiros dessas bactérias e registram também as plantas daninhas atuando como hospedeiros incidentais, fato que possibilita a manutenção dos patógenos no campo, mesmo na ausência de tomate ou pimentão.

A mancha-bacteriana tem distribuição mundial, sendo encontrada desde a Oceania até a América do Norte, causando sérios prejuízos para as culturas de tomate e pimentão (Hayward \& Waterson, 1964; Jones \& Stall, 1998). No Brasil, a doença foi relatada 
primeiramente por Batista em 1947 na região Nordeste, causando prejuízos em mudas e plantações de pimentão, e um pouco mais tarde, no estado do Rio de Janeiro (Robbs, 1953).

A principal forma de sobrevivência da bactéria, entre safras, ocorre por meio de sementes e fragmentos infectados, como talos das plantas. Sementes contaminadas podem disseminar a bactéria a longas distâncias, podendo atingir 15\% de infecção, contudo sua viabilidade pode ser mantida por mais de 10 anos (Kurozawa e Pavan, 1997).

\subsection{Sintomatologia}

Apesar de infectar severamente a planta na sua fase inicial, a mancha-bacteriana pode causar danos em qualquer fase de seu desenvolvimento, sendo todos os órgãos aéreos da planta afetados (Kurozawa e Pavan, 1997).

A multiplicação da bactéria em alta quantidade nas folhas promove lesões com aspecto de manchas aquosas (Romeiro, 1995). Essas pequenas manchas podem-se unir, causando sintomas de necrose e posterior abscisão da folha. Com o avanço da doença, as folhas mais velhas apresentam lesões de formato irregular e cor verde-escura (Pernezny e Momol, 2005). Uma das principais características dessa doença é que as folhas amarelam e caem, resultando em menor produtividade da planta e na exposição dos frutos à queima pela incidência de raios solares. No caule, as lesões são pequenas e alongadas, de coloração marrom. Nos frutos, a bactéria causa manchas similares a verrugas, inicialmente esbranquiçadas e depois com centros escurecidos (Lopes \& Ávila, 2003) (Figura 1).

Frutos de Capsicum raramente apresentam sintomas, porém sua queda pode ocorrer devido à infecção precoce na planta. Os danos causados nos frutos são pouco comuns em virtude da instalação da bactéria só ocorrer por meio de lesões provocadas via danos mecânicos ou ação de insetos (Viñals et al., 1996). 


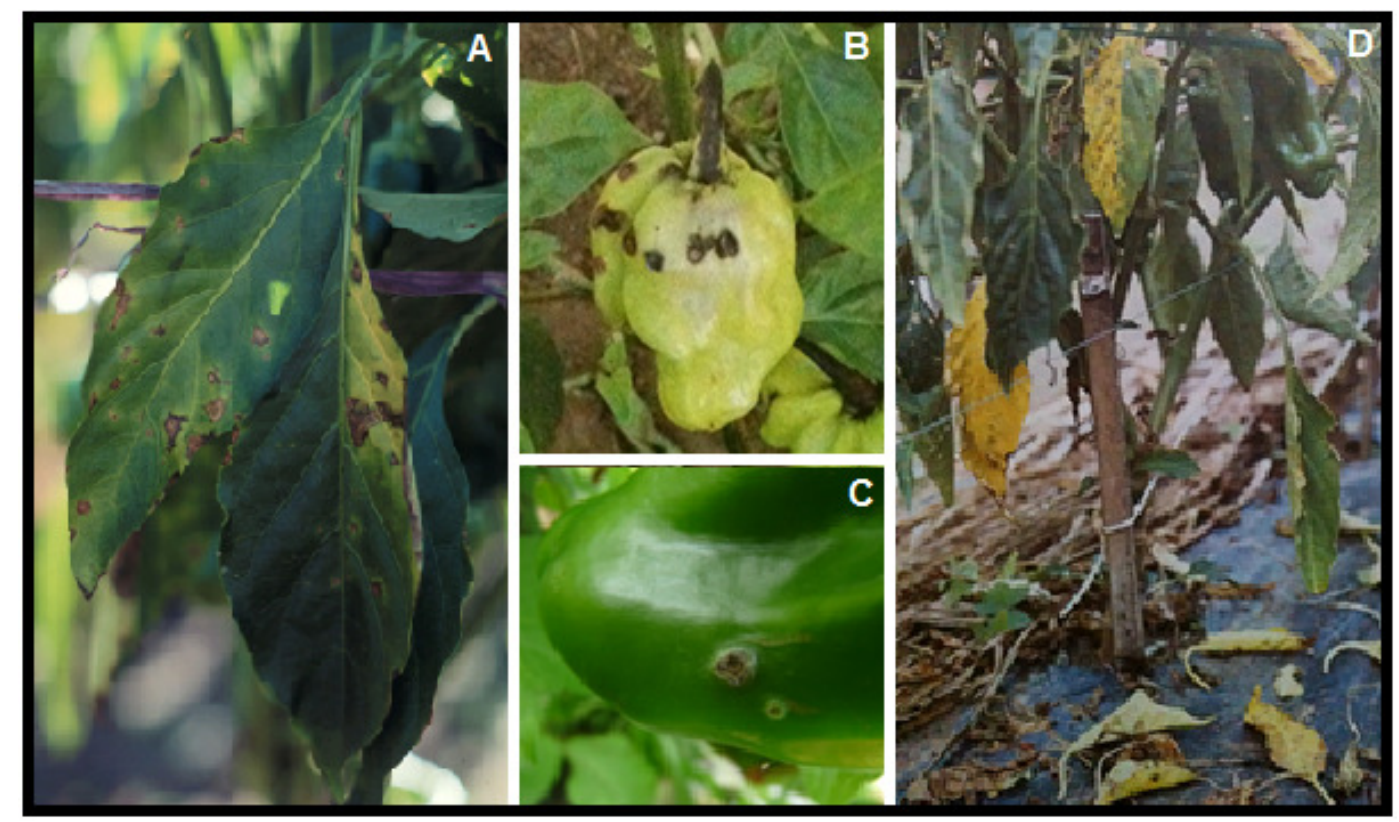

Figura 1. Sintomas de mancha-bacteriana em Capsicum. A- Lesões necróticas nas folhas; B e C- Lesões necróticas nos frutos de pimenta (Capsicum chinense) e pimentão (Capsicum annuит); D- Plantas com desfolha intensa. Fotos: Alice Quezado.

\subsection{Etiologia}

O complexo de espécies causadoras da mancha-bacteriana em pimenta e pimentão pertence ao gênero Xanthomonas. São bactérias baciliformes, Gram negativas, aeróbias e móveis por um flagelo polar (Jones et al., 1997). Possui colônias lisas, mucoides, amarelas pela presença do pigmento xantomonadina (Figura 2) (Stall, 1993). São classificadas dentro do domínio Bacteria, filo Proteobacteria, classe Gammaproteobacteria, ordem Xanthomonadales, família Xanthomonadaceae, gênero Xanthomonas (Garrity \& Holt, 2000). 


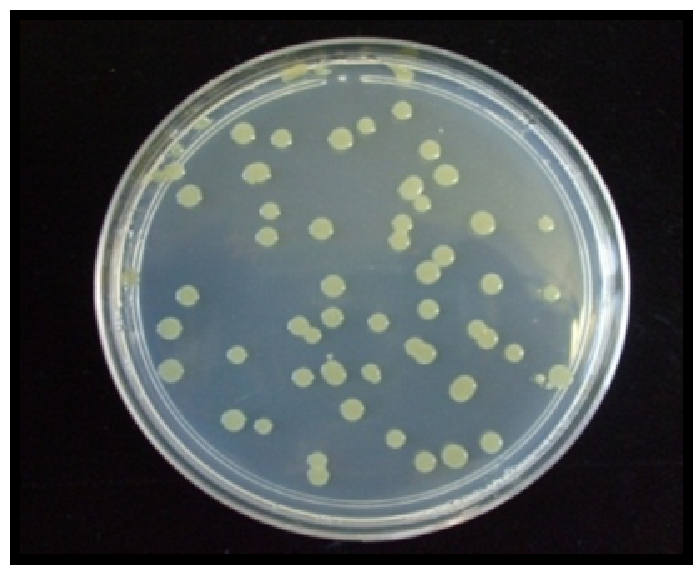

Figura 2. Colônias bacterianas amarelas típicas das espécies de Xanthomonas causadoras da mancha-bacteriana no gênero Capsicum, em meio ágar nutriente.

Em 1914, pela primeira vez foi observada a mancha-bacteriana em plantas de tomate na África do Sul e no ano de 1920, descrita como "tomato canker", por Doidge, que identificou uma fraca atividade amidolítica dos isolados analisados e nomeou a bactéria como Bacterium vesicatorium. Simultaneamente uma doença similar nos Estados Unidos foi denominada como "bacterial spot", ou mancha-bacteriana e seu agente causal apresentava forte atividade amidolítica, sendo este nomeado como Bacterium exitiosa (Gardner \& Kendrick, 1921). No mesmo período, Sherbakoff descreveu a doença em pimentão (Sherbakoff, 1918). Posteriormente, o agente causal foi classificado como Pseudomonas vesicatoria em 1925; Phytomonas vesicatoria em 1930 e Xanthomonas vesicatoria em 1939 (Jones \& Stall, 1998).

Alguns anos depois Sutic (1957) identificou uma doença bacteriana em tomateiro na Iugoslávia e Costa Rica e caracterizou uma variante da bactéria denominada Pseudomonas gardneri, estabelecendo uma variedade especial, X. gardneri var. capsici para isolados patogênicos ao pimentão (Jones et al., 1998) após foi colocada em sinonímia com Xanthomonas vesicatoria. A colocação de P. gardneri no gênero Xanthomonas foi sustentada por estudos de hibridização DNA:rRNA (Deley, 1979). Hildebrand et al. (1990) verificaram 
que $X$. gardneri estava mais relacionada a outras espécies do gênero, tais como $X$. hortorum pv. carotae, sendo considerada como um grupo a parte.

A variabilidade do patógeno começou a ser melhor esclarecida quando se observou que os isolados provenientes de tomate hidrolisavam amido e os de pimentão não (Burkholder \& Li, 1941). Posteriormente, Dye (1966) confirmou que isolados oriundos de pimentão hidrolisavam amido mais fracamente que aqueles de tomate. Logo, estabeleceu-se dois diferentes grupos causadores da mancha-bacteriana (Vauterin et al, 1995; 2000): Xanthomonas axonopodis pv. vesicatoria (grupo A, sem atividade amidolítica) e $X$. vesicatoria (grupo B, amidolítico positivo) (Tabela 1 ).

Estudos posteriores, incluindo testes de patogenicidade, bioquímicos, atividade enzimática, marcadores genéticos, hibridização DNA-DNA e comparação de sequências de RNA, concluíram que dentro do grupo das Xanthomonas patogênicas ao tomate e pimentão existem quatro grupos fenotípicos distintos, que foram classificados como três espécies distintas, a saber: $X$. axonopodis pv. vesicatoria (grupos A e C), X. vesicatoria (grupo B) e $X$. gardneri (Jones et al., 2000). Jones et al. (2004) propuseram uma reclassificação dos grupos A e C, Xanthomonas euvesicatoria e X. perforans, respectivamente, sendo este último inserido como um novo táxon entre os agentes causadores da mancha-bacteriana. Além disso, isolados de cada espécie podem ser caracterizados quanto a raças, de acordo com a capacidade de causar ou não reação de hipersensibilidade em variedades diferenciais de pimentão e tomate (Stall et al., 2009) (Tabela 1). 
Tabela 1. Histórico da classificação de Xanthomonas patogênicas a pimentão e tomate. Adaptado de Wierzbicki, 2004.

\section{Classificação}

Autores

Observou que isolados provenientes de tomate hidrolizavam amido e os

Burkholder \& Li, 1941 pimentão não;

Confirmou que isolados oriundos de pimentão hidrolizavam fracamente amido e os que aqueles de tomates;

Dye, 1966

Dois grupos geneticamente distintos;

Vauterin et al., 1990 Stall et al., 1994

Dois grupos: $X$. vesicatoria (apresentam atividade aminolítica); $X$. axonopodis pv. vesicatoria (não apresentam atividade aminolítica);

Vauterin et al., 1995

$X$. vesicatoria (sinonímia de $X$. campestrispv. vesicatoria- conforme Vauterin et al., 1995);

Dois grupos genética e fenotipicamente distintos: Grupo A ( $X$. axonopodis pv. vesicatoria) e Grupo B (X. vesicatoria). Grupo C relacionado ao A e Grupo D (X. gardneri) - geneticamente distinto de A e B;

Duas espécies distintas: $X$. vesicatoria - forte atividade aminolítica; e $X$. axonopodis- ausência de atividade aminolídica;

Estirpes de $X$. axonopodis pv. vesicatoria que pertenciam à estirpe tipo de $X$. Jones et al., 2000 axonopodis(Vauterin et al., 2000) apresentaram menos de 70\% de homologia com esta espécie e quatro grupos e três espécies foram classificadas: Grupo A e $\mathrm{C}(X$. axonopodis pv. vesicatoria $-\mathrm{C}=$ subespécie de $\mathrm{A})$; Grupo $\mathrm{B}(X$. vesicatoria) e Grupo D (X. gardneri);

Grupo A (X. euvesicatoria); Estirpes do Grupo D (X. gardneri) com menos de Young et al., 1996 Jones et al., 1998 $70 \%$ de homologia com outras espécies $=$ Grupo C (X.perforans- espécie nova).

Jones et al., 2004

\subsection{Epidemiologia}

As condições ideais de temperatura para o desenvolvimento da mancha-bacteriana em tomate e pimentão é entre 20 e $30^{\circ} \mathrm{C}$ (Lopes \& Quezado-Soares, 1994) e além de temperaturas altas a doença é favorecida por umidade relativa entre 95 e 100\%, e presença de água livre 
(Barreto \& Scaloppi, 2007). A entrada da bactéria no tecido da hospedeira ocorre por aberturas naturais (estômatos). Pequenas lesões causadas pelo vento, chuvas ou insetos também podem servir de porta de entrada para o patógeno (Kimura, 1984). A disseminação do patógeno se dá de planta para planta através da água das chuvas ou de irrigação associadas a ventos fortes (Carmo et al., 1996).

Araújo et al. (2011), em estudos desenvolvidos em relação ao efeito da temperatura $\left(20,25\right.$ e $\left.30^{\circ} \mathrm{C}\right)$ sobre a severidade da mancha-bacteriana causada por quatros espécies de Xanthomonas, observaram que $X$. gardneri foi mais agressiva que as demais espécies a $20^{\circ} \mathrm{C}$. Por sua vez, $X$. perforans incitou maior severidade a $30^{\circ} \mathrm{C}$. Não foi observado efeito significativo da temperatura sobre a severidade da doença para a espécie $X$. veiscatoria. Xanthomonas euvesicatoria foi a espécie menos agressiva.

O patógeno pode ser disseminado através das sementes (Kimura et al., 1989; Salles et al., 1991), podendo espalhar-se por respingos de água de chuva ou de irrigação e com a ajuda do homem (Jones et al., 1991; Lopes \& Quezado-Soares, 1997, Quezado-Duval \& Lopes, 2010).

As espécies de Xanthomonas causadoras da mancha-bacteriana em Capsicum não sobrevivem no solo por longos períodos, mas podem sobreviver em restos de cultura infectados (Jones et al., 1991; Quezado-Duval et al., 2008; Quezado-Duval \& Lopes 2010)

\subsection{Interação Xanthomonas spp. - Capsicum}

Xanthomonas euvesicatoria é patogênica ao tomateiro e ao gênero Capsicum e também pode causar hipersensibilidade em certos genótipos desse gênero (Sahin, 1997). Esta capacidade de causar hipersensibilidade em genótipos de Capsicum, provavelmente está relacionada com a perda do gene avrBsT (Minsavage et al., 1990). As demais espécies estão 
mais associadas ao tomate, mas existem relatos de isolados de $X$. gardneri isoladas do tomateiro com capacidade de infectar pimentão (Quezado-Duval \& Camargo 2004). No Brasil Xanthomonas vesicatoria tem sido relatada ocorrendo apenas no tomateiro, mas há relatos dessa espécie ocorrendo em pimentão na Bulgária e na Macedônia (Kizheva et al., 2013). Em Xanthomonas perforans, inicialmente associado ao tomateiro, foi recentemente relatada em ocorrência natural da doença em pimentão na Flórida (Bart et al., 2012).

A principal característica de muitas interações incompatíveis é a ocorrência de morte rápida da célula da planta no local ou ao redor do sítio de infecção em questão, conhecida como reação de hipersensibilidade (RH) (Figura 3B). A reação de hipersensibilidade em planta não hospedeira é o resultado de um gene de avirulência presente no patógeno. A herança dos genes de resistência não está caracterizada, porque não há suscetibilidade em Solanum lycopersicon às estirpes de pimentão, nem em Capsicum às estirpes de tomate. Porém, aceita-se que genes simples em pimentão e tomate sejam responsáveis pela resistência não hospedeira porque tem-se observado que os genes simples de avirulência do patógeno avrBsT e avrBsP, interagem com todas as plantas de Capsicum spp. e Solanum lycopersicon, respectivamente (Cook, 1973; Minsavage et al., 1990; Canteros et al., 1991; Jones et al., 1998).

Atualmente 11 raças (P0 a P10) foram relatadas para a espécie $X$. euvesicatoria em Capsicum. Raças são definidas de acordo com as reações de resistência e suscetibilidade em certas variedades da hospedeira (Leach \& White, 1996). Já em tomate, estão descritas quatro raças (T1/ X. euvesicatoria, T2/ X. vesicatoria e X. gardneri, T3/X.perforans e T4/X.perforans), mas que abrange o complexo o que dificulta o manejo da doença (Jones et al., 2005; Jones et al., 1998; Stall et all., 2009). No entanto, a nomenclatura utilizada não está apropriada à definição clássica de raças nesse caso, já que as quatro raças referem-se a distintas espécies de Xanthomonas. 
No gênero Capsicum a identificação de raças do patógeno é realizada com a observação da reação de hipersensibilidade em linhas quase isogênicas de pimentão Early California Wonder (ECW) de Capsicum annuum e em Capsicum pubescens PI 235047. Cada linha de Capsicum annuum carrega um gene distinto de resistência (Bs1, Bs2 ou Bs3) e $C$. pubescens o último gene proposto denominado Bs4 (Sahin \& Miller, 1998) (Tabela 2). Existem dois genes recessivos de resistência, não ligados à reação de hipersensibilidade, portanto não associados à resistência oferecida pelos genes ligados à reação de hipersensibilidade, sendo denominados bs 5 e $b s 6$ e em experimentos realizados, apresentaram resultados favoráveis de resistência raça não-específica (Jones et al., 2002).

Tabela 2. Genótipos diferenciais de raças de Xanthomonas euvesicatoria patogênica a Capsicum e genes de resistência identificados. Adaptado de Wierzbichi, 2004.

\begin{tabular}{cc}
\hline Linhagem / Gene de resistência & Resistência \\
\hline ECW - $10(B s 1)$ & Raças 0,2 e 5 \\
ECW - $20(B s 2)$ & Raças $0,1,2,3,7$ e 8 \\
ECW $-30(B s 3)$ & Raça $0,1,4,7$ e 9 \\
PI $-235047(B s 4)$ & Raça $0,3,4$ e 6 \\
ECW (Nenhum) & Suscetível \\
\hline
\end{tabular}

*Não há resistência descrita para raça 10. 
Tabela 3. Genes de resistência à mancha-bacteriana em acessos de Capsicum e genes de avirulência bacterianos que interagem com eles. Adaptado de Stall et al. (2009).

\begin{tabular}{ccccc}
\hline \multirow{2}{*}{ Genes de Resistência } & \multicolumn{2}{c}{ Planta } & Genes de & Bactéria \\
\cline { 2 - 5 } & Fonte & Espécie & avirulência & Localização \\
\hline$B s 1$ & CNPH 3002 (ECW 10-R) & C. annuum & avrBs1 & Plasmídeo \\
$B s 2$ & CNPH 3001 (ECW 20-R) & C. annuum & avrBs2 & Cromossomo \\
$B s 3$ & CNPH 3005 (ECW 30-R) & C. annuum & avrBs3 & Plasmídeo \\
$B s 4$ & PI 235047 & C. pubescens & avrBs4 & Plasmídeo \\
$b s 5$ & PI 163192 ou PI 271322 & C. annuum & ND* & ND \\
$b s 6$ & PI 163192 ou PI 271322 & C. annuum & ND & ND \\
$B s T$ & Pimentão comercial & C. annuum & avrBsT & Plasmídeo \\
\hline
\end{tabular}

*Não determinado.

Atualmente a espécie Xanthomonas gardneri ainda não foi classificada em nível de raças para reações de resposta ao gênero Capsicum. Já para tomate, de acordo com a reação de genótipos de uma série diferencial, isolados de X. gardneri se comportam como raça T2.

Um correspondente gene de avirulência $(a v r B s 7)$ provocou uma forte reação de hipersensibilidade em uma linhagem de Capsicum annuum (ECW-70R) que confere a presença de um gene dominante de resistência Bs7 (Potnis et al., 2012).

Homólogos do gene avrBs3 foram encontrados em muitos outras Xanthomonas patogênicas de plantas e alguns têm sido estudados (Schornack et al., 2006). Um homólogo do gene avrBs3 (avrBHahl) foi encontrado em uma estirpe de X. gardneri, causando reação de hipersensibilidade no pimentão que confere o gene de resistência $B s 3$ ). Esse gene avrHah1 só ocorre na espécie X. gardneri e é localizado no plasmídeo (Schornack et al., 2008).

A diversidade do grupo ainda gera discussões. Young et al. (2008) analisaram as sequências dos genes de housekeeping e propuseram que X. perforans e X. euvesicatoria fossem tratadas como espécies sinônimas. Já Potnis et al. (2011) analisaram o genoma completo das quatro espécies causadoras da mancha-bacteriana e afirmaram que estas espécies são distintas e que realmete devem ser tratadas como espécies diferentes. 
Segundo Potnis et al. (2015), devido a enorme diversidade presente no complexo da mancha- bacteriana do pimentão e tomateiro, o sequenciamento de genomas completos, está auxiliando, porém mais sequências são necessárias para a identificação de fatores de virulência chaves na infecção. Com o conhecimento desses fatores, será possível, através de técnicas de transgenia o desenvolvimento de linhagens resistentes, com maior amplitude e estabilidade de resistência. Os mesmos autores destacam a implementação de métodos de controle associando o uso de novos princípios ativos com efeito bactericida, rotação de cultura e cultivares resistentes.

\subsection{Diagnose molecular}

A diagnose da mancha-bacteriana pode ser feita pela observação dos sintomas e do fluxo bacteriano, testes bioquímicos, testes de patogenicidade para a observação dos sintomas característicos da doença, isolamento da bactéria em cultura pura e através de testes moleculares.

Por se tratar de um complexo de espécies de difícil identificação e separação por sintomatologia e testes bioquímicos, a identificação dessas espécies vem sendo realizada mais eficientemente por meio de técnicas moleculares, principalmente utilizando PCR com iniciadores específicos (Koenraadt et al., 2009; Moretti et al., 2009; Araújo et al., 2012).

Leite Jr. et al. (1995) realizaram testes moleculares utilizando o método de reação em cadeia da polimerase (PCR) e detectaram Xanthomonas spp. em sementes de tomate e pimentão, utilizando os iniciadores RST2/RST3 com amplificação de uma banda de DNA de 840 pb e os iniciadores com amplificação de uma banda de DNA de 355 pb.

O método de rep-PCR faz uso de sequências oligonucleotídicas iniciadoras complementares de sequências de DNA repetitivas presentes em numerosas cópias no genoma. As sequências repetitivas são denominadas: REP (repetitive extragenic palindromic) 
com cerca de 35 pares de bases (Stern et al., 1984), as quais são conservadas, ERIC (enterobacterial repetitive intergenic consensus) de 126 pares de bases (Sharples \& Lloyd, 1990), as quais contêm um elemento repetitivo central invertido altamente conservado e que estão localizados em regiões intergênicas, e BOX de 154 pares de bases (Martin et al., 1992). Os iniciadores utilizados contêm sequências correspondentes a esses elementos e esse método consiste no anelamento dos iniciadores ("primers") nessas regiões descritas anteriormente amplificando a região desconhecida entre elas. O método além de ser usado para diagnose, também é empregado para a diferenciação de isolados, avaliando a diversidade genética de patógenos de plantas (Louws et al., 1999).

A técnica de rep-PCR com o iniciador BOX apresenta vantagens por ser rápida, de fácil execução e altamente discriminatória para espécies de Xanthomonas. Segundo Rademaker et al. (2000), métodos que geram fingerprintings, como o de rep-PCR, apresentam elevada correlação com a homologia DNA-DNA, reafirmando a especificidade e eficiência desta técnica na identificação de espécies bacterianas.

Iniciadores específicos foram desenvolvidos para as espécies de Xanthomonas causadoras da mancha-bacteriana. O uso da PCR com tais iniciadores pode vir a ser um método rápido, sensível e específico para a detecção e identificação das espécies envolvidas, em novas áreas (Koenraadt et al., 2009). A partir de sequenciamento de fragmentos de DNA obtidos por AFLP, foram desenvolvidos iniciadores específicos para as quatro espécies de Xanthomonas (Koenrradt et al., 2009). Moretti et al. (2009) desenvolveram iniciadores específicos que foram desenhados a aprtir da sequência de fragmento de DNA obtidos por rep-PCR. Araújo et al. (2013), desenvolveram e validaram iniciadores específicos para $X$. vesicatoria a partir de DNA purificado, suspensões bacterianas e lesões foliares em tomateiro. Além disso, uma alternativa para o emprego dos iniciadores específicos pode ser por meio de PCR multiplex, onde as espécies do complexo da mancha-bacteriana são identificadas 
simultaneamente (Pulawska et al., 2006; Berg et al., 2006; Robène-Soustrade et al., 2010; Araújo, 2012).

\subsection{Controle químico e resistência ao cobre}

Um eficiente controle da mancha-bacteriana depende da combinação de algumas práticas culturais: uso de plântulas e sementes livres do patógeno, limpeza da área, rotação de cultura, tratamento químico e uso de cultivares resistentes (Silva-Lobo et al., 2005). É importante que esse controle seja realizado desde o plantio até a colheita (Lopes \& QuezadoSoares, 1997).

O controle químico da mancha-bacteriana é baseado na pulverização periódica com fungicidas à base de cobre. Fungicidas cúpricos atuam na proteção do tecido vegetal contra infecção e na redução da população bacteriana na superfície foliar. Entretanto, são necessárias várias aplicações desses produtos para alcançar o controle adequado da doença, pois o excesso de cobre pode causar toxidez às células bacterianas, afetando suas funções metabólicas (Kurylowicz, 1981).

A eficiência do controle químico à base de fungicida cúprico é bastante variável e na maioria das vezes ineficiente. Em experimento realizado em campo por Carmo et al., (2001), plantas infectadas foram submetidas a tratamentos com e sem aplicações de oxicloreto de cobre, em diferentes épocas do ano. Como resultado, foi constatado que em épocas de altas temperaturas e elevada precipitação havia maior intensidade da doença. A isso foi atribuído o fato de que com o aumento da temperatura, há maior frequência nas irrigações e na aplicação de fungicidas, e com isto pode haver o desenvolvimento de variantes resistentes ao longo do período de pulverização provocado pela constante lavagem do produto e exposição a subdosagens. Quando um indivíduo da população bacteriana adquire a resistência, essa 
característica é selecionada pela pressão de seleção, que nesse caso é a constante aplicação de produtos a base de cobre (Sundin et al., 1989).

Vários relatos demonstram a baixa eficiência de estreptomicina e cúpricos para o controle da mancha-bacteriana (Marco \& Stall, 1983; Quezado-Duval et al., 2003). O aparecimento de indivíduos resistentes nas populações bacterianas é apontado como a principal causa dessa ineficiência (Minsavage et al., 1990, Sahin, 1997; Bauzar, et al., 1999).

Em 1983 na Flórida ocorreu o primeiro relato da resistência ao cobre em Xanthomonas campestris pv. vesicatoria (Marco \& Stall, 1983). Essa resistência ao cobre pode ser medida por genes encontrados em plasmídeos ou em DNA cromossômico (Cooksey, 1990; Minsavage et al., 1990; Voloudakis et al., 1993; Lee et al., 1994).

Nos estudos de sensibilidade a cobre com isolados brasileiros de Xanthomonas spp. causadoras da mancha-bacteriana, não se tem observado uma insensibilidade significativa dos isolados a altas concentrações do produto (Quezado-Duval et al., 2005; Costa et al., 2012). Contudo, um acompanhamento periódico da sensibilidade dessas espécies é importante para se verificar quais os níveis de insensibilidade ao cobre que esses isolados vem adquirindo nos últimos anos.

Isolados de bactérias fitopatogênicas resistentes ao cobre foram encontrados em espécies de Pseudomonas (Andersen et al., 1991; Bender et al., 1986; Cazorla et al., 2002; Scheck et al., 1998; Sundin et al., 1989) , Pantoea (Nischwitz et al., 2007) , Erwnia (AlDaoude et al., 2009) e outras espécies de Xanthomonas (Behlau et al., 2011; Lee et al., 1994; Marco et al., 1983; Stall et al., 1986. Genes associados a tolerância ao cobre foram identificados por Behlau et al. (2011) em isolados de Xanthomonas citri subsp. citri e X. alfafae subsp. citrumelonis. Foram encontrados também genes homólogos ao gene cop, os genes coh presentes no cromossomo que não são responsáveis pela resistência ao cobre e sim pela homeostase (Behlau et al., 2011). 


\subsection{Resistência de Capsicum à mancha-bacteriana}

Alguns programas de melhoramento com o objetivo de se obter cultivares de Capsicum resistentes à mancha-bacteriana têm sido conduzidos em diferentes instituições. A Empresa Brasileira de Pesquisa Agropecuária possui um banco de germoplasma com 650 acessos de Capsicum spp. (Embrapa, 2007). O Instituto Nacional de Pesquisas da Amazônia (INPA) desenvolve, desde 1976, um programa de melhoramento genético do pimentão visando incorporar resistência a Xanthomonas spp. (Noda et al., 2003). Já na Universidade Estadual do Norte Fluminense Darcy Ribeiro (UENF), a partir do cruzamento entre UENF 1421 (pimentão suscetível) e UENF 1381 (pimenta resistente), 18 linhas recombinadas promissoras para a resistência e produção de frutos foram obtidas, utilizando-se o SSD (Single Seed Descent), como método de melhoramento (Riva, 2006).

A avaliação de cultivares de Capsicum destina-se à escolha de genótipos que sejam geneticamente resistentes a doenças e pragas, e com características agronômicas desejáveis, alta produtividade e adaptação às regiões de cultivo (Peixoto et al., 1999). Sabe-se que a expressão fenotípica de caracteres variáveis depende do genótipo da cultivar, bem como do ambiente onde é plantada. Assim, o estudo da interação genótipo x ambiente torna-se necessário nos programas de melhoramento (Cruz et al., 2004).

$\mathrm{Na}$ escolha de um genótipo para ser plantado em determinado local, é sempre desejável que existam ensaios visando à seleção dos mais adaptados. Recomenda-se, inicialmente, plantios em escala experimental e, somente depois de obtidos resultados preliminares, deverão ser realizados plantios em maior escala, com menor número de genótipos (Oliveira et al., 2001). Esse procedimento é importante para a indicação de novas cultivares de qualquer hortaliça, pois o comportamento de cada genótipo depende do ambiente como um todo, principalmente do clima, solo e forma de cultivo. 
No manejo da mancha-bacteriana é recomendado também o uso de cultivares resistentes (Kurozawa et al., 2005). No mercado brasileiro, recentemente foram disponibilizados híbridos de pimentão com genes específicos de resistência a algumas raças da espécie X. euvesicatoria causadora da mancha-bacteriana em Capsicum, sendo: Impacto (Seminis, 2014); Commandant (Syngenta, 2014), Dahra RX (Sakata, 2014) e Paloma (Horticeres, 2015).

\section{JUSTIFICATIVA}

Xanthomonas spp. agentes causadores da mancha-bacteriana são capazes de diminuir a produção e depreciar os frutos para comercialização. A dificuldade do controle da manchabacteriana ainda persiste em virtude de: eficiência variável do controle químico, principalmente pelo aparecimento de populações bacterianas insensíveis; pouca disponibilidade de variedades resistentes aliada à grande variabilidade do(s) patógeno(s), pois o patógeno se especializou em nível de raças, e a sua disseminação por sementes contaminadas (Quezado-Duval, 2004). O esclarecimento da frequência de espécies e raças associadas à mancha-bacteriana do pimentão; a elucidação dos níveis de sensibilidade que esses isolados apresentam ao cobre, bem como a identificação de fontes de resistência à doença, são informações de fundamental importância para a adoção de estratégias de manejo mais eficientes. 


\section{OBJETIVO GERAL}

Identificar espécies e raças de Xanthomonas associadas à mancha-bacteriana em Capsicum que ocorrem em alguns estados do Brasil e avaliar in vitro a sensibilidade dos isolados ao cobre.

\section{OBJETIVOS ESPECÍFICOS}

(1) Caracterizar isolados de Xanthomonas obtidos de amostras sintomáticas de Capsicum da coleção (1982-2014) de trabalho do Laboratório de Fitopatologia da Embrapa Hortaliças, utilizando iniciadores específicos e a técnica de BOX-PCR;

(2) Investigar a ocorrência de raças de Xanthomonas que afetam a cultura de pimentão e pimenta em diferentes estados do Brasil, pela inoculação em genótipos diferenciadores;

(3) Testar, in vitro, a sensibilidade ao cobre dos isolados de Xanthomonas da coleção (1982-2014) de Capsicum do Laboratório de Fitopatologia da Embrapa Hortaliças. 


\section{REFERÊNCIAS BIBLIOGRÁFICAS}

AL-DAOUDE, A.; ARABI, M.I.E.; AMMOUNEH, H. 2009. Studying Erwinia amylovora isolates from Syria for copper resistance and streptomycin sensitivity. Journal Plant Pathology 91:203-205.

ANDERSEN, G.L.; MENKISSOGLOU, O.; LINDOW, S.E. 1991. Occurrence and properties of copper-tolerant strains of Pseudomonas syringae isolated from fruit trees in California. Phytopathology 81:648-656.

ARAÚJO, E.R.; COSTA, J.R.; FERREIRA, M.A.S.V.; QUEZADO-DUVAL, A.M. 2013. Specific primers for Xanthomonas vesicatoria, a tomato bacterial spot causal agent. European Journal of Plant Pathology. Amsterdan 137(5):5-9.

ARAÚJO, E.R.; COSTA, J.R.; FERREIRA, M.A.S.V.; QUEZADO-DUVAL, A.M. 2012. Simultaneous detection and identification of the Xanthomonas species complex associated with tomato bacterial spot using species-specific primers and multiplex PCR. Journal of Applied Microbiology 113(6):1479-1490.

ARAÚJO, E.R.; PEREIRA, R.C.; FERREIRA, M.A.S.V.; CAFÉ-FILHO, A.C.; MOITA, A. W.; QUEZADO-DUVAL, A.M. 2011. Effect of temperature on pathogenicity components of tomato bacterial spot and competition between Xanthomonas perforans and X. gardneri. Acta Horticulturae, The Hague 914:39-42.

BARRETO, M.; SCALOPPI, E.A.G. 2007. Sistema de previsão de doenças de hortaliças. In: ZAMBOLIM, L. Ed. Manejo integrado - doenças pragas e plantas daninhas. Viçosa UFV, p.169-189.

BART, R.; SHARLACH, M.; KASSEN, A.; POTNIS, N.; MINSAVAGE, G. V.; STASKAWICZ, B. J.; JONES, J. B. 2012. How high-throughput sequencing technology helps our understanding of plant-pathogenic bacteria (ouverview). APS Annual Meeting. Providence, RI. 
BASHAN, Y.; AZAIZEH, S.; DIAB, S.; YUNIS, H.; OKON, Y. 1985. Crop loss of peper plants artificially infected with Xanthomonas campestris pv. vesicatoria in relation to symptom expression. Crop protection 4(1):77-84.

BENDER, C.L.; COOKSEY, D.A. 1986. Indigenous plasmids in Pseudomonas syringae pv. tomato: Conjugative transfer and role in copper resistance. J. Bacteriol 165:534-541.

BEHLAU, F.; HONG, J.C.; JONES, J.B.; GRAHAM, J.H. 2013. Evidence for acquisition of copper resistance genes from different sources in citrus associated xanthomonads. Phytopathology 103:409-418.

BEHLAU, F.; CANTEROS, B.I.; MINSAVAGE, G.V.; JONES, J.B.; GRAHAM, J.H. 2011. Molecular characterization of copper resistance genes from Xanthomonas citri subsp. citri and Xanthomonas alfafae subsp. citrumelonis. Appl. Environ. Microbiol. 77:4089-4096.

BOUZAR, H.; JONES, J.B.; STALL, R.E.; LOUWS, F.J.; SCHNEIDER, M.; RADEMAKER, J.L.W.; BRUIJN, F.J.; JACKSON, L.E. 1999. Multiphasic analysis of xanthomonads causing bacterial spot disease on tomato and pepper in the Caribbean and Central America: evidence for common lineages within and between countries. Phytopathology 89:328-335.

BURKHOLDER, W.H., LI, C.C. 1941. Variation in Phytomonas vesicatoria. Phytopathology 31: 753-755.

CANTEROS, B.I.; MINSAVAGE, G.V.; BONAS, V.; PRING, D.; STALL, R.E. 1991. A gene from Xanthomonas campestris pv. vesicatoria that determines avirulence in tomato is related to avrBS3. Molecular and Plant-Microbe Interactions 4(6):628-632.

CARMO, M.G.F.; MACAGNAN, D.; CARVALHO, A.D. 2001. Progresso da manchabacteriana do pimentão a partir de diferentes níveis iniciais de inóculo e do emprego ou não do controle com oxicloreto de cobre. Horticultura Brasileira, Brasília 19(3):210-215. 
CARMO, M.G.F.; KIMURA, O.; MAFFIA, L.A.; CARVALHO, A.O. 1996. Progresso da pústula bacteriana do pimentão, causada por Xanthomonas campestris pv. vesicatoria, em condições de viveiro. Fitopatologia Brasileira, Brasília 21:(1):62-70.

CARVALHO, S.I.C.; BIANCHETTI, L.B.; RIBEIRO, AC.S.C.; LOPES, C.A 2006. Pimentas do gênero Capsicum no Brasil. Embrapa Hortaliças, Brasília, DF. 27p.

CARVALHO, H.H.; WIEST, J.M.; CRUZ, F.T. 2010. Atividade antimicrobiana in vitro de pimentas e pimentões (Capsicum sp.) sobre quatro bactérias toxinfectantes alimentares. Revista Brasileira de Plantas Medicinais 12(1):8-12.

CAZORLA, F.M.; ARREBOLA, E.; SESMA, A.; PÉREZ-GARCÍA, A.; CODINA, J. C.; MURILlO, J.; DE VICENTE, A. 2002. Copper resistance in Pseudomonas syringae strains isolated from mango is encoded mainly by plasmids. Phytopathology 92:909-916.

COOK, A.A. 1973. Characterization of hypersensitivity in Capsicum annuum induced by the tomato estirpe of Xanthomonas vesicatoria. Phytopathology 63:1260-1265.

COOKSEY, D.A. 1990. Genetics of bactericide resistance in plant pathogenic bacteria. Annual Review of Phytopathology, Palo Alto 28:201-219.

COSTA, J.R.; ARAÚJO, E.R.; BECKER, W.F.; FERREIRA, M.A.S.V.; QUEZADODUVAL, A.M. 2012. Ocorrência e caracterização do complexo de espécies causadoras da mancha-bacteriana do tomateiro no Alto Vale do Rio do Peixe, SC. Tropical Plant Pathology 37(2):149-154.

COSTA, R.A.; RODRIGUES, R.; SUDRÉ, C.P. 2002. Resistência genética à manchabacteriana em genótipos de pimentão. Horticultura Brasileira 20:86-89.

CRUZ, C.D.; REGAZZI, A.J.; CARNEIRO, P.C.S. 2004. Modelos biométricos aplicados ao melhoramento genético. UFV: Imprensa Universitária, p.390. 
DELEY, J. 1979. Modern molecular methods in bacterial taxonomy: evaluation, application, prospects. In: International Conference on Plant Pathogenic Bacteria, 4, Angers. Procedings. Angers. p.347-357.

DOIDGE, E.M. 1920. A tomato canker. Journal of Department of Agriculture Union South Africa 1:718-721.

DYE, D.W. 1996. Cultural and biochemical reaction of additional Xanthomonas species. New Zealand Journal of Science 9:913-919.

EPPO. 2003. Quarantine pest: Xanthomonas vesicatoria, EPPO A2 list: (157):6.

FILGUEIRA, F.A.R. 2008. Novo Manual de Olericultura: agrotecnologia moderna na produção e comercialização de hortaliças. Cultura e comercialização de hortaliças. 3 ed. Viçosa: UPV, 421p.

GARDNER, M.W.; KENDRICK, J.B. 1921. Bacterial spot of tomato. Journal of Agricultural Research 21:123.

GARRITY, G.M.; HOLT, J.G. 2000. An overview of the road map to the manual. Systematic Bacteriology. 2ed. New York. Springer. p.20.

GELETA, L.F.; LABUSCHANGNE, M.T. 2004. Comparative performance and heterosis in single, three-way and double cross pepper hybrids. The Journal of Agricultural Science, 142:659-663.

HAYWARD, A.G., WATERSON, J.M. 1964. Xanthomonas vesicatoria: descriptions of pathogenic fungi and bacteria. Kew Surrey: Commonwealth Mycological Institute Press, 2p.

HILDEBRAND, D.C.; PALLERONI, N.J. \& SCHROTH, M.N. 1990. Deoxyribonucleic acid relatedness of 24 xanthomonads strains representing 23 Xanthomonas campestris pathovars and Xanthomonas fragariae. Jounal of Applied Bacteriology, 8:263-269. 
IBPGR Genetic resources of Capsicum. Rome. 1983.

JONES, J.B.; LACY, G.H.; BOUZAR, H.; MINSAVAGE, G.V.; STALL, R.E.; SCHAAD, N.W. 2005. Bacterial spot. Worldwide distribution, importance and review. Acta Horticulturae 695:27-33.

JONES, J.B.; LACY, G.H.; BOUZAR, H.; STALL, R.E.; SCHAAD, N.W. 2004. Reclassification of the xanthomonads associated with bacterial spot disease of tomato and pepper. Systematic and Applied Microbiology 27:755-762.

JONES, J.B.; MINSAVAGE, G.V.; ROBERTS, P.D.; JOHNSON, R.R.; KOUSIK, C.S.; SUBRAMANIAN, S.; STALL, R.E. 2002. A non-hypersensitive in pepper to the bacterial spot pathogen is associated with two recessive genes. Phytopathology 92:273-277.

JONES, J.B.; BOUZAR, H.; STALL, R.E.; ALMIRA, E.C.; ROBERTS, P.D.; BOWEN, B.W; SUDBERRY, J.; STRICKLER, P.M.; CHUN, J. 2000. Systematic analysis of xanthomonads (Xanthomonas ssp.) associated with pepper and tomato lesions. International Journal of Systematic Bacteriology 50:1211-1219.

JONES, J.B.; STALL, N. R. E. 1998. Diversity among Xanthomonads pathogenics on pepper and tomato. Annual Review of Phytopathology 36:41-58.

JONES, J.B.; STALL, R.E.; ZITTER, T.A. 1997. Compendium of tomato diseases. St Paul: American Phytopathological Society Press. 27p.

JONES, J.B., JONES, J.P., STALL, R.E., ZITTER, T.A. 1991. Compendium of tomato diseases. St Paul: APS Press. 73p.

KIMURA, O.; STRALIOTTO, R.; SUDO, A.; MURANAGA, M. 1989. Eficiência de transmissão de Xanthomonas campestris pv. vesicatoria em sementes de pimentão. Fitopatologia Brasileira, v.14, p.126, 1989. 22 ${ }^{\circ}$ Congresso Brasileiro de Fitopatologia, Campinas. 
KIMURA, O. 1984. Melhoramento do pimentão visando à resistência à "pústula bacteriana". Informe Agropecuário 10(113):41-44.

KIMURA, O., ROBBS, C.F., RIBEIRO, R.L.D., AKIBA, F., SUDO, S. 1972. Identificação de patotipos de Xanthomonas campestris pv. vesicatoria (DOIDGE) Dowson, ocorrendo na região centro-sul do Brasil. Arquivos do Instituto Biológico 39:43-49.

KLEMENT, Z. 1963. Rapid detection of the patogenicity of phytopatogenic Pseudomonads. Nature 199:299-300.

KOENRAADT, H.; VAN BETTERA,Y. B.; GERMAIN, R.; HIDDINK, G.; JONES, JB, OOSTERHO, F. J.; RIJLAARSDAM, A.; ROORDA, P.; WOULDT, B. 2009. Development of specific primers for the molecular detection of bacterial spot of pepper and tomato. Acta Horticulturae 808: 99-102.

KUROSAWA, C.; PAVAN, M.A. 1997. Doenças das solanáceas (berinjela, jiló, pimentão e piementa). In: KIMATI, H., AMORIM, L., BERGAMIM FILHO, A.B., CAMARGO, L.E.A., REZENDE, J.A.M. (eds.) Manual de Fitopatologia: doenças das plantas cultivadas. v.2. 3. ed. São Paulo: Agronômica Ceres, p. 665-675.

KUROZAWA, C; PAVAN, M.A; KRAUSE-SAKATE. R. Doenças das solanáceas. In: KIMATI, H. (Eds.). 2005. Manual de Fitopatologia. São Paulo: Agronômica Ceres, p. 591592.

KURYLOWICZ, W. 1981. Antibióticos - Uma revisão crítica. Recife. Universidade Federal Rural de Pernambuco. 341p.

LEACH, J.E.; WHITE, F.F. 1996. Bacterial avirulence genes. Annual Review Phytopathology 34:153-179. 
LEE, Y.; HENDSON, M.; PANOPOULOS, N.J.; SCHROTH, M.N. 1994. Molecular cloning, chromosomal mapping and sequence analysis of copper resistance genes from Xanthomonas campestris pv. julglandis: homology with small blue copper proteins and multicopper oxidase. Journal of Bacteriology 176(1):173-188.

LEITE, J.R.R.P.; JONES, J.B.; SOMODI, G.C.; MINSAVAGE, G.V.; STALL, R.E. 1995. Detection of Xanthomonas campestris pv. vesicatoria associated with pepper and tomato seed by DNA amplification. Plant Disease 79(9):917-922.

LOPES, C.A.; ÁVILA, A.C. 2003. Doenças do pimentão: diagnose e controle. Brasília: Embrapa Hortaliças, 96p.

LOPES, C.A.; QUEZADO-SOARES, A.M. 1997. Doenças Bacterianas das Hortaliças Diagnose e controle. Brasília: Embrapa - CNPH. 70p.

LOUWS, F.J.; RADEMAKER, J.L.W.; BRUIJIN, F.J. 1999. The three D's of PCR-based genomic analysis of Phytobacteria: diversity, detection and disease diagnosis. Annual Review of Phytopathology 37:81-125.

MARCO, G. M.; STALL, R. E. 1983. Control of bacterial spot of pepper initiated by strains of Xanthomonas campestris pv. vesicatoria that differ in sensitivity to copper. Plant Disease 67(7):779-781.

MARIANO, R.L.R. 2000. Manual de práticas em fitobacteriologia. Recife: O Autor. cap.7, p. 65-66: Reação de hipersensibilidade a bactérias fitopatogênicas.

MARTIN, B.; HUMBERT, O.; CAMARA, M.; GUENZI, E.; WALKER, J.; MITCHELL, T.; ANDREW, P.; PRUDHOMME, M.; ALLOING, G.; HAKENBECK, R.; MORRISON, D.A.; BOULNOIS, G.J.; CLAVERYS, J.P. 1992. A highly conserved repeated DNA element located in the chromosome of Streptococcus pneumonia. Nucleic Acids Res, 20:3479-3483. 
MinSAVAGE, G. V.; DAHLBECK, D.; WHALEN, M. C.; KEARNEY, B.; BONAS, V.; STASKAWICZ, B. J.; STALL, R. E. 1990. Gene for-gene relation ships specifying disease resistance in Xanthomonas campestris pv. vesicatoria - Pepper Interactions. Molecular and Plant-Microbe Interactions 3(1):41-47.

MONGKOLPORN, O.; TAYLOR, P.M.J. 2011. Capsicum. In: KOLE, C. (ed.) Wild crop relatives: genomic and breeding resources vegetables. Berlin: Springer-Verlag, p. 43-57. MOREIRA, G.R.; CALIMAN, F.R.B.; SILVA, D.J.H.; RIBEIRO, C.S.C. 2006. Espécies e variedades de pimenta. Informe Agropecuário, Belo Horizonte 27:16-29.

MORETTI, C.; AMATUlli, M.T.; BUONAURIO, R. 2009. PCR-based assay for the detection of Xanthomonas euvesicatoria causing pepper and tomato bacterial spot. Letters in Microbiology 49:466-471.

NISCHWITZ, C.; GITAITIS, R.; SANDERS, H.; LANGSTON, D.; MULLINIX, B.; TORRANCE, R.; BOYHAN, G.; ZOLOBOWSKA, L. 2007. Use of fatty acid methyl ester profiles to compare copper-tolerant and copper-sensitive strains of Pantoea ananatis. Phytopathology 97:1298-1304.

NODA, H.; MACHADO, F.M.; MARTINS, A.L.U. 2003. Seleção de genótipos de pimentão resistentes à Xanthomonas campestris pv. vesicatoria (Doidge) Dye. sob diferentes condições naturais de infecção. Acta Amazônica 33(3):371-380.

OLIVEIRA, A.P.; ANDRADE, A.C.; TAVARES SOBRINHO, J.; PEIXOTO, N. 2001. Avaliação de linhagens e cultivares de feijão-vagem, de crescimento indeterminado, no município de Areia-PB. Horticultura Brasileira 19(2):159-162.

OLIVEIRA, A.B.; SILVA, A.M.; LOPES, C.A.; RIBEIRO, C.S.C.; LOPES, D.; CRUZ, D.M.R.; MARQUES, D.M.C.; FRANÇA, F.H.; REIFSCHNEIDER, F.J.B.; BUSO, G.S.C.; BIANCHETTI, L.B.; FERREIRA, M.E.; POZZOBON, M.T.; RESENDE, R.O.; CARVALHO, S.I.C.; PINHEIRO, V.L.; CASALI, V.W.D. 2000. Capsicum: pimentas e pimentões no Brasil. Brasília: Embrapa Hortaliças. 92p. 
PEIXOTO, J.R.; RAMOS, R.S.; FARIAS JÚNIOR, B.; SILVA, C.M.; DE ANGELIS, B. 1999. Avaliação de genótipos de pimentão no período de inverno em Araguari, MG.Pesquisa Agropecuária Brasileira 34(10):1865-1869.

PERNEZNY, K.; MOMOL, T. 2005. Florida plant disease management guide: Pepper. University of Florida - Ifas Extension, p.1-4.

PICKERSGILL, B. 1997. Genetic resource and breeding of Capsicum spp. Euphytica 96:129133.

PIERRE, M.; NOËL, L.; LAHAYE, T.; BALIVORA, A.; VEUSKENS, J.; GANAL, M.; BONAS, U. 2000. High-resolution genetic mapping of the pepper resistance lócus Bs3 governing recognition of the Xanthomonas campestris pv. vesicatoria AvrBs3 Protein. Theor. Appl. Genet. 101:255-263.

POTINIS, N.; TIMILSINA, S.; STRAYER, A..; SHANTHARAJ, D.; BARAK, J. D.; PARET, M. L.; VALLD, G. E.; JONES, J.B. 2015. Bacterial spot of tomato and pepper: diverse Xanthomonas species with a wide variety of virulence factores posing a worldwide challenge. (NO PRELO).

POTINIS, N.; MINSAVAGE, G.; SMITH, J.K.; HURLBERT, J.C.; NORMAN, R.R.; STALL, R.E.; JONES, J.B. 2012. Avirulence proteins AvrBs7 from Xanthomonas gardneri and AvrBs1.1 from Xanthomonas euvesicatoria contribute to a novel gene-for-gene interaction in pepper. Mol. Plant Microbe Interact 25(3):307-320.

POTNIS, N.; KRASILEVA, K.; CHOW, V.; ALMEIDA, N.F.; PATIL, P.B.; RYAN, R.P.; SHARLACH, M.; BEHLAU, F.; DOW, J.M.; MOMOL, M.T.; White, F.F.; PRESTON, J.F.; VINATZER, B.A.; KOEBNIK, R.; SETUBAL, J.C.; NORMAN, D.J.; STASKAWICZ, B.J.; JONES, J.B. 2011. Comparative genomics reveals diversity among xanthomonads infecting tomato and pepper. BMC Genomics 12:146. 
QUEZADO-DUVAL, A.M. .; LOPES, C.A. 2010. Mancha-bacteriana: uma atualização para o sistema de produção integrada de tomate indústria. Brasília: Embrapa Hortaliças, Circular Técnica 84:28.

QUEZADO-DUVAL, A.M.; GUIMARÃES, C.M.N.; SILVA, C.S. 2008. Tigueras: uma fonte de inoculo inicial da mancha-bacteriana em tomate para processamento industrial. Boletim de pesquisa e desenvolvimento. Embrapa Hortaliças. 16p.

QUEZADO-DUVAL, A.M.; LOPES, C.A.; LEITE JUNIOR, R.P.; LIMA, M.F.; CAMARGO, L.E. A. 2005. Diversity of Xanthomonas spp. associated with bacterial spot of processing tomatoes in Brazil. Acta Horticulturae, The Hague 695:101-108.

QUEZADO-DUVAL, A.M; GAZZOTO FILHO, A.; LEITE JÚNIOR, R.P.; CAMARGO, L.E.A. 2003. Sensibilidade a cobre, estreptomicina e oxitetraciclina em Xanthomonas spp. Associadas à mancha-bacteriana do tomate para processamento industrial. Horticultura Brasileira 21(4):670-675.

QUEZADO-SOARES, A.M.; LOPES, C.A. 1999. Controle químico da mancha-bacteriana em tomateiro para processamento industrial. Summa Phytopathologica 25:21.

RADEMAKER, J.L.W.; HOSTER, B.; LOUWS, F.J.; KERSTERS, K.; SWINGS, J.; VAUTERIN, L.; VALTERIN, P.; BRUIJIN, F.J. 2000. Comparison of AFLP and rep-PCR genomic fingerprinting with DNA homology studies: Xanthomonas as a model system. International Journal of Systematic and Evolutionary Microbiology 50:665-677.

RIBEIRO, C.S.C.; CARVALHO, I.C. de C.; LOPES, C.A.; REIFSCHNEIDER, F.J.B. 2008. Pimentões e pimentas do gênero Capsicum. In: ALBUQUERQUE, A.C.S \& SILVA, A.G. da Agricultura Tropical - quatro décadas de inovações tecnológicas, institucionais e políticas. Embrapa Informação Tecnológica, Brasília, DF, 1:595-608.

RIVA, E.M.; RODRIGUES, R.; PEREIRA, M.G.; SUDRÉ, C.P., KARASAWA, M.; AMARAL JUNIOR, A.T. 2004a. Inheritance of bacterial spot disease in Capsicum annuum L. Crop Breeding and Applied Biotechnology 4(4):490-494. 
ROBBS, C.F.A.; NETO, J.R., RIBEIRO, R.L.D., KIMURA, O. 1981. Annotated list of bacterial plant pathogens in Brazil. In: International conference on plant pathogenic bacteria, Colômbia. Proceedings. Cali: DDA Press. p. 601-613.

ROBBS, C.F.A. 1953. "Mancha-bacteriana” do pimentão (Capsicum annuum L.). Agricultura e Pecuária. Rio de Janeiro. Editora Terra. p. 25-32.

ROMEIRO, R. S. Bactérias Fitopatogênicas. 1995. Viçosa, Imprensa Universitária - UFV, $367 p$.

ROMERO, A.M.; KOUSSIK, C.S.; RITCHIE, D.F. 2002. Temperature sensitivity oh the hypersensitive response of bell pepper to Xanthomonas axonopodis pv. vesicatoria. Phytopathology 92(2):197-203.

SAHIN, F.; MILLER, S. A. 1998. Resistance in Capsicum pubescens to Xanthomonas campestris pv. vesicatoria pepper race 6. Plant Disease 82(7):794-799.

SAHIN, F. 1997. Detection, identification and characterization of strains of Xanthomonas campestris pv. vesicatoria by tradicional and molecular methods, and resistance in Capsicum species to Xanthomonas campestris pv. vesicatoria pepper race 6. Columbus, 182p. Thesis (Ph.D.) - The Ohio State University.

SAHIN, F.; MILLER, S.A. 1996. Characterization of Ohio strains of Xanthomonas campestris pv. vesicatoria, causal agent of bacterial spot of pepper. Plant Disease 80(7):11091112.

SAKATA. Pimentão Dahra RX. Bragança Paulista: Sakata Seed Sudamerica. 2014. Disponível em <http://www.sakata.com.br/produtos/hortalicas/solanaceas/pimentao>. Acesso em: 13 fev. 2014. 
SALLES, M.R.M.; KIMURA, O.; RIBEIRO, R.L.D.; AKIBA, F. 1991. Sementes: importante fonte de inoculo de Xanthomonas campestris pv. vesicatoria para culturas comerciais de pimentão no Brasil. Fitopatologia Brasileir 16 (1):41. $24^{\circ}$ Congresso Brasileiro de Fitopatologia, Belo Horizonte.

SCHECK, H.J.; PSCHEIDT, J.W. 1998. Effect of copper bactericides on copper-resistant and -sensitive strains of Pseudomonas syringae pv. syringae. Plant Dis. 82:397-406.

SCHORNACK, S.; MEYER, A.; RÖMER, P.; JORDAN, T.; LAHAYE, T. 2006. Gene-forgene mediated recognition of nuclear-targeted AvrBs3-like bacterial effector proteins. Journal of Plant Physiology 163:256-272.

SCHORNACK, S.; MINSAVAGE, G.V.; STALL, R.E.; JONES, J.B.; LAHAYE, T. 2008. Characterization of AvrHah1, a novel AvrBs3-like effector from Xanthommonas grdneri with virulence and avirulence activity. New Phytol 179:546-556.

SEMINIS. Impacto. St. Louis: Seminis Grow Forward. 2014. Disponível em , http://www.seminis.com/global/br/products/Pages/Impacto.aspx>. Acesso em: 13 fev. 2014.

SHARPLES, G.J.; LLOYD, R.G. 1990. A novel repeated DNA sequence located in the intergenic regions of bacterial chromosomes. Nucleic Acids Research 18:6503-6508.

SHERBAKOFF, C.D. 1918. Report of the associate plant pathologist. Florida Agriculture Experiment Station Report 1916-1917:66R-86R.

SILVA-LOBO, V.L.; LOPES, C.A.; GIORDANO, L.B. 2005. Componentes da resistência à mancha-bacteriana e crescimento de Xanthomonas campestris pv. vesicatoria, raça $\mathrm{T} 2$, em genótipos de tomateiro. Fitopatologia Brasileira 30:17-20.

STALL, R.E.; JONES, J.B.; MINSAVAGE, G.V. 2009. Durability of resistance in tomato and pepper to xanthomonads causing bacterial spot. Annual Review of Phytopathology $47: 265284$. 
STALL, R.E.; BEAULIEU, C.; HODGE, N.C.; LEITE, R.P.; MINSAVAGE, G.V.; BOUZAR, H.; JONES, J.B.; ALVARES, A.M.; BENEDICT, A.A. 1994. Two genetically diverse groups of estirpes are include in a pathovar of Xanthomonas capestris. International Journal of Systematic Bacteriology 44(1):47-53.

STALL, R.E. 1993. Xanthomonas campestris pv. vesicatoria: cause of bacterial spot of tomato and pepper. In: SWINGS, J.G.; CIVEROLO, E.L. (Eds.). Xanthomonas. CHAPMAN \& HALL, London, p. 57-60.

STALL, R. E.; LOSCHKE, D. C.; JONES, J. B. 1986. Linkage of copper resistance and avirulence loci on a self-transmissible plasmid in Xanthomonas campestris pv. vesicatoria. Phytopathology 76:240-243.

STERN, M.J.; AMES, G.F.L.; SMITH, N.H.; ROBINSON, E.C.; HIGGIS, C.F. 1984. Repetitive extragenic palindromic sequences: a major component of the bacterial genome. Cell 37:1015-1026.

SUNDIN, G.W.; JONES, A.L.; FULBRIGHT, D.W. 1989. Copper resistance in Pseudomonas syringae pv. syringae from cherry orchards and its associated transfer in vitro and planta with a plasmid. Phytopathology 79:861-865.

SUNDIN, G.W.; DEMEZAS, D.H.; BENDER, C.L. 1994. Genetic and plasmid diversity within natural populations of Pseudomonas syringae with various exposures to copper and streptomycin bactericides. Applied and Environmental Microbiology 60:4421-4431.

SUTIC, D. 1957. Bakterioze crvenog patlidzana (Tomato bacteriosis). Posebna Izd. Inst. Zasht. Bilja Beograd (Spec. Edit. Inst. Plant Prot. Beograd) 6:1-65. English summary: Rev. Appl. Mycol 36:734-35.

SOUZA, M.F.R.; RODRIGUES, R.; AMARAL JUNIOR,. A.T.; SUDRÉ, C.P. 2008. Resistance to Xanthomonas spp. in tomato: diallel analysis and gene effects estimative in a breeding programme carried out in Brazil. Journal of Phytopathology 156:660-667. 
SYNGENTA. Pimentão Híbrido Commandant. São Paulo: Syngenta do Brasil. 2014. Disponível em: < http://www.syngenta.com/country/br/pt/produtosemarcas/sementes/ vegetais/Pages/pimentao-hibrido-commandant.aspx>. Acesso em: 13 fev. 2014.

VAUTERIN, L.; RADEMAKER, J.; SWINGS, J. 2000. Synopsis on the taxonomy of the genus Xanthomonas. Phytopathology 90:677-682.

VAUTERIN, L.; HOSTE, B.; KERSTERS, K.; SWINGS, J. 1995. Reclassification of Xanthomonas. International Journal of Systematic Bacteriology 45:472-489.

VAUTERIN, L.; SWINGS, J.; KERSTERS, K.; GILLIS, M.; MEW, T.W. 1990. Towards an improved taxonomy of Xanthomonas. International Journal of Systematic Bacteriology 40:312-316.

VIÑALS, F.N.; ORTEGA, R.G.; GARCIA, J.C. 1996. El cultivo de pimientos, chiles y ajies. Madrid: Mundi-Prensa, 607p.

VOLOUDAKIS, A.E.; BENDER, C.L. COOKSEY, D.A.1993. Similarity between copper resistance genes from Xanthomonas campestris and Pseudomonas syringae. Applied and Environmental Microbiology 59(5):1627-1634.

WIERZBICKI, R. 2004. Identificação de raças de Xanthomonas spp. patogênicas a pimentão no estado de São Paulo. Dissertação (Mestrado). Escola Superior de Agricultura Luiz de Queiroz, Piracicaba, SP, 62p.

YOUNG, J.M.; SADDLER, G.S.; TAKIKAWA, U.; DE BOER, S.H.; VAUTERIN, L.; GARDAN, L.; GVOZDYAK, R.I.; STED, D.E. 1996. Names of plant pathogenic bacteria 1864-1995. Review of Plant Pathology 75(9):721-763.

YOUNG, J.M., PARK, D.C., SHEARMAN, H.M., FARGIER, E. 2008. A multilocus sequence analysis of the genus Xanthomonas. Systematic and Applied Microbiology. 31:366377. 


\section{CAPÍTULO 1}

Espécies e raças de Xanthomonas associadas à mancha-bacteriana em Capsicum 
ESPÉCIES E RAÇAS DE XANTHOMONAS ASSOCIADAS À MANCHA-BACTERIANA EM CAPSICUM

\section{RESUMO}

As pimentas e os pimentões são cultivados em todas as regiões do Brasil. A mancha-bacteriana, causada por espécies de Xanthomonas, é uma das principais doenças que atacam plantas do gênero Capsicum, sendo X. euvesicatoria mais comumente associada a essas culturas. Até o momento, 11 raças de $X$. euvesicatoria foram descritas. Este trabalho objetivou identificar espécies e raças de Xanthomonas associadas à mancha-bacteriana de plantas do gênero Capsicum no Brasil. Setenta e seis isolados oriundos de campos comerciais de pimentas e pimentões, no período de 1982 a 2014, foram coletados no Distrito Federal e nos estados do Ceará, Bahia, Sergipe, Pernambuco, Pará, Amazonas, Roraima, Espírito Santo, Minas Gerais, São Paulo e Goiás. Os isolados foram caracterizados por meio de testes de patogenicidade em plantas suscetíveis de pimentão, teste de hipersensibilidade na série diferencial de raças de pimentão, quanto ao perfil genômico pela técnica de BOX-PCR, PCR com iniciadores específicos às Xanthomonas associadas à mancha-bacteriana e presença/ausência do gene avrRxv por PCR. Para a determinação das raças utilizou-se as linhagens quase-isogênicas de pimentão Early California Wonder - ECW, ECW-10R, ECW-20R, ECW-30R. Setenta e um isolados foram identificados como X. euvesicatoria. Quatro isolados, coletados na região Sudeste, foram $X$. gardneri e um isolado do Ceará foi $X$. perforans. Pela não disponibilidade do genótipo PI 235047 de $C$. pubescens, alguns isolados foram descritos como pertencentes a duas raças alternativas. Foram observadas as seguintes raças dos isolados de X. euvesicatoria coletados por estado: Ceará - raças 5, 0, 3 ou 8, 6 ou 10 e 4 ou 9; Bahia - raças 3 ou 8, 4 ou 9 e 7; Pernambuco - raça 5 e 6 ou 10; Sergipe - raça 0; Amazonas - raças 0, 3 ou 8 e 4 ou 9; Roraima - raça 6 ou 10; Pará - raça 5; Goiás - raças 5, 4 ou 9 e 1 ou 7; Distrito Federal - raças 0, 5, 3 ou 8, 4 ou 9 e 6 ou 10; Minas Gerais - raças 0, 5, 1 ou 7, 3 ou 8, 4 ou 9 e 6 ou 10; São Paulo - raças 1 ou 7, 2, 5 e 4 ou 9 e Espírito Santo - raça 4 ou 9. O esclarecimento das espécies e raças causadoras da mancha-bacteriana associadas ao gênero Capsicum no Brasil é o primeiro passo para o direcionamento de estudos que visem à aquisição de um melhor nível de controle da doença no campo pelo emprego da resistência varietal obtida por meio de melhoramento genético. Considera-se que neste estudo é feito o primeiro relato da ocorrência natural de $X$. gardneri e $X$. perforans em lavouras comerciais de Capsicum spp. no Brasil, bem como das raças 4 ou 9, 6 ou 10 de $X$. euvesicatoria.

Palavra-chave: Xanthomonas euvesicatoria, X. gardneri, X. perforans, PCR, pimentas e pimentões. 


\title{
SPECIES AND RACES OF XANTHOMONAS ASSOCIATED WITH BACTERIAL SPOT IN CAPSICUM
}

\begin{abstract}
Peppers and bell peppers are grown in all regions of Brazil. Bacterial spot, caused by Xanthomonas species, is one of the main diseases which attacks Capsicum plants. Among the xanthomonads associated to bacterial spot, Xanthomonas euvesicatoria has most commonly found in these crops. Up to date, 11 strains of $X$. euvesicatoria have been described. This study aimed to identify the Xanthomonas species and races associated with bacterial spot of Capsicum plants in Brazil. Seventy-six isolates from commercial fields of peppers and bell peppers, during the period from 1982 to 2014, were collected in the Distrito Federal and the states of Ceará, Bahia, Sergipe, Pernambuco, Pará, Amazonas, Roraima, Espírito Santo, Minas Gerais, São Paulo and Goiás. The isolates were characterized by pathogenicity tests on susceptible bell peppers, hypersensitivity test on a race differential series of bell pepper, whereas the genomic profile was characterized by BOX-PCR, PCR with primers specific to Xanthomonas associated with bacterial spot and presence / absence of $a v r R x v$ gene by PCR. For the identification of the races near isogenic lines of Early California Wonder bell pepper - ECW, ECW-10R, 20R-ECW, ECW30R were used. Seventy-one isolates were identified as X. euvesicatoria. Four isolates collected in the Southeast, were $X$. gardneri and one isolate from Ceará was X. perforans. In the absence of the genotype PI 235047 of $C$. pubescens in the presente study, some isolates were described as belonging to two alternatives races. The following races of $X$. euvesicatoria by state were observed: Ceará - races 5, 0, 3, 8, 6, or 109 or 4; Bahia - races 3 and 8, 4 or 9 and 7; Pernambuco - Race 5 and 6 races or 10; Sergipe - race 0; Amazon - races 0, 3, 8 and 4, or 9; Roraima - Race 6 or 10; Para - Race 5; Goiás - races 5, 4 or 9 and 1 or 7; Federal District - races $0,5,3,8,4$ or 9 and 6 or 10; Minas Gerais - races $0,5,7$ or 1, 3 or 8, 4 or 9 and 6 or 10; São Paulo - Races 1 or 7, 2, 5 and 4 or 9 and Espírito Santo - Race 4 or 9. The elucidation of species and races that cause bacterial spot associated with Capsicum in Brazil is the first step to drive the studies for the resistant variety development in order to better control the disease. It is considered that this study presents the first report of a natural occurrence of X. gardneri and X. perforans on Capsicum spp. at commercial fields in Brazil, as well as the races 4 or 9, 6 or 10 of $X$. euvesicatoria.
\end{abstract}

Keywords: Xanthomonas euvesicatoria, X. gardneri, X. perforans, PCR, peppers and bell peppers. 


\section{INTRODUÇÃO}

Os agentes causadores da mancha-bacteriana em Capsicum pertence ao gênero Xanthomonas. Jones et al. (2004) reclassificaram os agentes etiológicos originalmente agrupados em X. campestris pv. vesicatoria nas seguintes espécies: X. euvesicatoria (grupo A), X. vesicatoria (grupo B), X. perforans (grupo C) e X. gardneri (grupo D). Anteriormente somente as espécies $X$. euvesicatoria, $X$. gardneri eram associadas ao gênero Capsicum, porém mais recentemente, X. perforans foi relatada na Flórida (Bart et al., 2012) e X. vesicatoria na Macedônia e na Bulgária (Kizheva et al., 2013).

A diferenciação das espécies de Xanthomonas que formam o complexo da manchabacteriana pode ser realizada por meio de ensaios bioquímicos (atividade amilolítica), patogenicidade em tomate e pimentão, mas com maior eficiência e rapidez por meio de técnicas moleculares, rep-PCR ou PCR com iniciadores específicos (Louws et al., 1999; Bouzar et al., 1999; Cuppels et al., 2006; Koenraadt et al., 2009; Moretti et al., 2009). A técnica de rep-PCR com o iniciador BOX apresenta vantagens por ser rápida, de fácil execução e altamente discriminatória para espécies de Xanthomonas. Segundo Rademaker et al. (2000), métodos que geram fingerprintings, como o de rep-PCR, apresentam elevada correlação com a homologia DNA-DNA, reafirmando a especificidade e eficiência desta técnica na identificação de espécies bacterianas.

Além dos métodos moleculares, características fenotípicas também podem ser utilizadas para diferenciar algumas espécies de Xanthomonas. Jones et al. (2004), observaram que X. perforans e $X$. vesicatoria são fortemente amilolíticas e pectolíticas, já $X$. euvesicatoria é fracamente amilolítica e pectolítica e X. gardneri é caracterizada por não hidrolisar amido.

Os genes hrp codificam proteínas envolvidas na elicitação da reação hipersensibilidade (RH) em plantas não hospedeiras ou na patogenicidade em plantas hospedeiras (Niepold et al., 1985; Lindgren et al., 1986). 
Flor (1942), em sua teoria gene-a-gene, afirma que a resistência de uma determinada cultivar a uma determinada raça de fungo, é o resultado da interação entre o produto do gene de avirulência ( $a v r)$ do patógeno e o produto do gene de resistência do hospedeiro. Com isso, este tipo de interação entre os genes de resistência das plantas e os genes de avirulência dos patógenos, limitariam a distribuição dos patógenos. No caso das bactérias, duas classes de genes bacterianos podem sobrepor suas funções nos genes hrp - mediadores de compatibilidadeincompatibilidade entre plantas e bactérias: os genes de avirulência $(a v r)$ e vários genes de virulência, sendo que o primeiro regula a incompatibilidade genótipo-específica em plantas resistentes e o segundo promove a produção dos sintomas necessários à virulência da bactéria. (Gopalan \& Yang He, 1996).

As relações planta-bactéria, através da interação entre os $h r p$ e os genes $a v r$ do patógeno, assumiram especial importância para a definição do método de identificação dos genes de resistência. Então, no patossistema pimentão - Xanthomonas spp., os genes avr estariam diretamente relacionados às raças do patógeno e os genes hrp como mediadores de compatibilidade-incompatibilidade.

Com relação à variabilidade, ressalta-se o registro de 11 raças da espécie $X$. euvesicatoria descritas na literatura (Minsavage et al., 1990; Ritchie et al., 1998; Sahin \& Miller, 1998). Genes que conferem resistência específica (de efeito "hipersensível”) a determinadas raças também foram encontrados ( $B s 1, B s 2, B s 3, B s 4$ ), assim como genes de efeito mais amplo ("não hipersensível") (bs5 e $b s 4)$. A identificação desses dois genes recessivos de resistência, derivados de PI-271322 (bs5) e PEP 13 (bs6), foi feita por Jones et al. (2002).

As raças descritas foram baseadas na reação de hipersensibilidade (RH), em linhas quase isogênicas da cv. Early California Wonder (ECW) de Capsicum annuum e em C. pubescens PI235047. Cada linha de C. annuum carrega um gene distinto de resistência (Bs1, Bs2 ou Bs3), enquanto o acesso de $C$. pubescens, proposto posteriormente para compor a série diferencial de 
raças, carrega um gene denominado Bs4 (Sahin \& Miller, 1998). As isolinhas de ECW são denominadas: ECW - suscetível a todas as raças de X. euvesicatoria conhecidas; ECW 10R, ECW 20R, ECW 30R e o PI-235047, que apresentam genes de resistência para raças específicas.

As interações planta-bactéria podem ser geralmente classificadas como compatíveis ou incompatíveis. Em uma interação compatível, uma planta hospedeira suscetível é infectada por uma bactéria virulenta (ou compatível), resultando na multiplicação e colonização da bactéria no tecido da planta infectada, e no aparecimento dos sintomas da doença. Em uma interação incompatível, uma bactéria avirulenta (ou incompatível), penetra uma planta hospedeira resistente ou uma planta não hospedeira, mas a multiplicação e colonização da bactéria são severamente restritas (Gopalan \& Yang He, 1996). A principal característica de muitas interações incompatíveis é a ocorrência de morte rápida da célula da planta no local ou ao redor do sítio de infecção em questão, conhecida como reação de hipersensibilidade - RH (Klement, 1963; Goodman \& Novacky, 1994). A RH em plantas não hospedeiras, ocorre devido a um gene de avirulência presente no patógeno (Cook, 1973; Canteros et al., 1991).

A maior parte das estirpes de X. euvesicatoria identificadas na década de 1990 carregava um ou mais genes de avirulência (Porhonezny et al., 1992), embora para a raça 6, até 1996, não tenha sido identificado nenhum gene de avirulência (Sahin \& Miller, 1996). Atualmente, somente a raça 10 não apresenta nenhum gene de avirulência conhecido. Dois genes de avirulência (avrBs1 e avrBs2) estão presentes em plasmídeo (Jones et al., 1998) e podem ser perdidos ou mutados com maior frequência (Dahlbeck \& Stall, 1979; Swords et al., 1996), resultando em genes inativos, caracterizando a "quebra" de resistência da hospedeira. A quebra de resistência pelo patógeno ocorre principalmente devido à alta taxa de mutação descrita para os genes avrBs1 (Dahlbeck \& Stall, 1979) e avrBs2 (Swords et al., 1996). Esta mutação, resulta na "quebra" dos genes de resistência $B s 1$ e $B s 2$, respectivamente. A maioria desses genes de avirulência estão presentes em plasmídeos, podendo ser trocados naturalmente através de 
conjugação entre estirpes, com isso, as raças resultantes não são necessariamente estáveis (Canteros et al., 1995) proporcionando assim, uma alta variabilidade ao grupo Xanthomonas spp. que ataca pimentão e tomate (Jones et al., 1998).

As raças 1 e 3 de X. euvesicatoria, de acordo com Sahin \& Miller (1996), prevalenciam nos Estados Unidos. Em levantamento realizado no Brasil, em campos de produção de pimentão no estado de São Paulo, Kobori \& Wierzbicki (2000) relataram a ocorrência das raças 0, 1, 2, 3, 7 e 8 do patógeno.

A perda do plasmídeo contendo o gene $a v r B s 3$, também resulta em quebra do gene $B s 3$ (Minsavage et al., 1990). O que se observa é que todos os genes maiores dominantes para resistência ao patógeno foram vencidos por pelo menos uma raça (Kousik \& Ritchie, 1999).

O presente trabalho teve como objetivo identificar espécies e raças de Xanthomonas associadas à mancha-bacteriana em Capsicum de isolados obtidos de amostras coletadas em lavouras comerciais brasileiras.

\section{MATERIAL E MÉTODOS}

Os experimentos foram realizados no Laboratório de Fitopatologia e em casas de vegetação da Embrapa Hortaliças, Brasília - DF, no período de fevereiro de 2013 a novembro de 2014.

\section{Obtenção dos isolados}

Os isolados de Xanthomonas associadas a mancha-bacteriana em Capsicum spp. usados pertencem à coleção de trabalho de bactérias fitopatogênicas da Embrapa Hortaliças, preservados em tampão fosfato $\left(\mathrm{K}_{2} \mathrm{HPO}_{4}, \mathrm{KH}_{2} \mathrm{PO}_{4}, \mathrm{pH}\right.$ 7.0) sob temperatura ambiente. Utilizou-se isolados obtidos em quatro regiões geográficas brasileiras, compreendendo isolados do Centro Oeste 
(Distrito Federal e Goiás), Norte (Amazonas, Pará e Roraima), Nordeste (Ceará, Bahia, Sergipe e Pernambuco) e Sudeste (Espírito Santo, São Paulo e Minas Gerais) (Tabela 2).

Para isolamento bacteriano retirou-se uma área na intersecção entre tecido sadio e doente para proceder a desinfestação. Para a desinfestação do material, imergiu-se a amostra em álcool $70 \%$ por 10 segundos, água sanitária $1 \%$ por 30 segundos, com posterior tríplice lavagem em água estéril. Após esse processo, macerou-se o tecido, obtendo-se um extrato que foi riscado em meio de cultura NA (nutriente ágar), contendo 3,0 g/L de extrato de carne; 5,0 g/L de peptona; 2,5 g/L de sacarose e $17 \mathrm{~g} / \mathrm{L}$ de ágar, e incubado a $28^{\circ} \mathrm{C}$ por 3 a 4 dias. As colônias típicas do gênero Xanthomonas foram repicadas e posteriormente preservadas em tampão fosfato a temperatura ambiente.

\section{Identificação das espécies de Xanthomonas associadas ao gênero Capsicum}

Um total de 76 associados a plantas do gênero Capsicum da coleção do Laboratório de Fitopatologia da Embrapa Hortaliças foram identificados através de testes de patogenicidade e testes de identificação molecular (Tabela 2).

\section{Teste de patogenicidade}

Os isolados foram recuperados do tampão fosfato em meio NA (Nutriente Agar), contendo $3 \mathrm{~g} / \mathrm{L}$ de extrato de carne; $5 \mathrm{~g} / \mathrm{L}$ de peptona; $17 \mathrm{~g} / \mathrm{L}$ de ágar e $2,5 \mathrm{~g} / \mathrm{L}$ de sacarose e incubados por 4 dias a $28^{\circ} \mathrm{C}$. Após o crescimento bacteriano, repicou-se uma colônia recobrindo toda a área do meio de cultura (NA) de uma nova placa, incubando-a por mais 48 horas a $28^{\circ} \mathrm{C}$, para posterior preparo da suspensão. Preparou-se uma suspensão bacteriana em sulfato de magnésio (10mMol/l) com concentração aproximada de $5 \times 10^{8} \mathrm{UFC} / \mathrm{ml}$, ajustada em espectrofotômetro $\left(\mathrm{OD}_{600 \mathrm{~nm}}=0,3\right)$. Utilizou-se borrifadores manuais para aspergir a suspensão sobre a área foliar das plantas quando estas apresentavam de 4 a 6 folhas verdadeiras. Após a 
inoculação, as plantas foram submetidas à câmara úmida por 48 horas no interior de sacos plásticos umedecidos. Quinze dias após a inoculação, fez-se a avaliação das plantas quanto à presença de sintomas. Utilizaram-se os acessos CNPH 1375 (ECW) ou CNPH 193 (Yolo Wonder) para os testes patogenicidade, pois são genótipos sabidamente suscetíveis (JONES et al., 2000) .

\section{Extração de DNA}

A extração foi realizada segundo protocolo de Mahuku (2004). Para tal, após o crescimento do isolado em meio líquido caldo nutriente (Nutrient Broth - NB) por um período de 16 a 24 horas, transferiu-se 1,5 mL do meio contendo bactéria para microtubos (capacidade 1,5 mL) identificados com o número de cada amostra, e centrifugou-se a 13.000 rotações por minuto (rpm) por 5 minutos para precipitar as células em microcetrífuga ((Eppendorf®). Após a centrifugação, adicionou-se $1000 \mu \mathrm{L}$ de Água destilada autoclavada, agitou-se o tubo em agitador de bancada (Votex $®)$ e centrifugou-se novamente por 5 minutos. Após, o sobrenadante foi descartado com cuidado para não perder o pellet e adicionou-se $200 \mu \mathrm{L}$ de TE, $30 \mu \mathrm{L}$ de SDS e $10 \mu \mathrm{L}$ de proteinase $\mathrm{K}$. Posteriormente, os tubos foram agitados e colocados em banho-maria por 30 a 40 minutos a temperatura de $65^{\circ} \mathrm{C}$. Em seguida, adicionou-se $250 \mu \mathrm{L}$ de acetato de amônio 7,5 M, agitou-se novamente e a amostra foi incubada no congelador por 10 minutos. Após, foi centrifugada por 20 minutos a $13.000 \mathrm{rpm}$ e transferiu-se o sobrenadante $(\sim 400 \mu \mathrm{L})$ para novo tubo. Adicionou-se $400 \mu \mathrm{L}$ de isopropanol, e em seguida as amostras foram incubadas no congelador por 1 a 2 horas. Posteriormente, centrifugou-se por 20 minutos, descartou-se o sobrenadante, adicionou-se $800 \mu \mathrm{L}$ de etanol $70 \%$, com posterior centrifugação por 5 minutos. Em seguida, foi descartado o etanol e o tubo foi colocado para secar no fluxo laminar por algumas horas ou overnight. Por último, ressuspendeu-se cada amostra em $50 \mu \mathrm{L}$ de TE com RNAse. 


\section{Identificação molecular das espécies}

Foram utilizados iniciadores específicos para $X$. euvesicatoria (Bs-XeF/R) e (CATGAAGAACTCGGCGTATCG e GTCGGACATAGTGGACACATAC) que amplificam um fragmento de 173pb, para X. gardneri (Bs-XgF/R) (TCAGTGCTTAGTTCCTCATTGTC e TGACCGATAAAGACTGCGAAAG) que amplificam um fragmento de 154pb (Koenraadt et al., 2009). Além disso foi utilizado iniciador BOX 1AR (5' CTACGGCAAGGCGACGCTGA CG 3') correspondente a sequência repetitiva BOX (Versalovic et al., 1991). Para a reação de BOX-PCR utilizou-se Tampão $1 \mathrm{X} ; 1,5 \mathrm{mM}$ de $\mathrm{MgCl}_{2} ; 0,2 \mathrm{mM}$ de cada dNTPs; $2 \mu \mathrm{M}$ do iniciador; 1,26 U de Taq DNA polimerase; e água milliQ para um volume final de $12 \mu \mathrm{L} \mathrm{A}$ concentração do DNA utilizado foi de aproximadamente $50 \mathrm{ng}$. As amostras foram amplificadas em termociclador My Cycler ${ }^{\mathrm{TM}}$ (BIO RAD). O programa utilizado para amplificação foi $95^{\circ} \mathrm{C}$ por 7 min., seguido de 30 ciclos de: $94^{\circ} \mathrm{C}$ por 1 minuto para a desnaturação, $53^{\circ} \mathrm{C}$ por 1 minuto para anelamento e $65^{\circ} \mathrm{C}$ por 8 minutos para a extensão. A extensão final foi realizada a $65^{\circ} \mathrm{C}$ por 15 minutos. Os produtos de PCR foram analisados em gel de agarose $(1,5 \%)$ em tampão TBE 0,5X, por eletroforese conduzida a $100 \mathrm{~V}$ durante 3 horas. $\mathrm{O}$ gel de agarose foi corado com brometo de etídio e visualizados sobre luz ultravioleta. Como referência e/ou controle positivo das reações de PCR foram utilizados isolados provenientes da coleção de bactérias fitopatogênicas do Instituto Biológico de São Paulo, a saber, IBSBF 2363 (Xanthomonas euvesicatoria), IBSBF 2364 (Xanthomonas vesicatoria), IBSBF 2370 (Xanthomonas perforans) e IBSBF 2373 (Xanthomonas gardneri).

Avaliou-se também a presença do gene avrRxv, relacionado à hipersensibilidade em genótipo de tomateiro portador do gene de resistência $R x v$, porém, característico da espécie $X$. euvesicatoria, como uma ferramenta adicional para identificação. Os iniciadores específicos RST 27 (5'- AGT CGC GCG GAC ATT TAG CCC CGC C) e RST 28 (5'-CGT CGA TGG TGC GCC TGG AAT GCG C) (Bouzar et al., 1999) foram utilizados para verificar a presença 
desse gene. A reação foi composta por tampão $1 \mathrm{X} ; 1,5 \mathrm{mM}$ de $\mathrm{MgCl}_{2} ; 0,1 \mathrm{mM}$ de cada dNTP; $0,5 \mu \mathrm{M}$ de cada primer; $0,3 \mathrm{U}$ de Taq DNA polimerase; e aproximadamente $50 \mathrm{ng}$ de DNA em um volume final de $50 \mu \mathrm{l}$. As reações foram realizadas em termociclador My CyclerTM (BIO RAD) com temperatura inicial de $95^{\circ} \mathrm{C}$ por cinco minutos, seguidos de 30 ciclos de $95^{\circ} \mathrm{C}$ por 30 segundos (desnaturação), $64^{\circ} \mathrm{C}$ por 30 segundos (anelamento), e $72^{\circ} \mathrm{C}$ por 45 segundos (extensão). A extensão final foi a $72^{\circ} \mathrm{C}$ durante 5 minutos.

Para verificação do tamanho de bandas geradas pelas diferentes técnicas, foram utilizados marcadores moleculares 1Kb DNA Ladder ou 100pb DNA Ladder da Invitrogen®.

\section{Identificação das raças}

\section{Genótipos diferenciais das raças}

Como padrão de suscetibilidade foi utilizado o pimentão cv. Early California Wonder (ECW), que não possui nenhum gene conhecido de resistência à Xanthomonas spp. (O' Garro et al., 1999). Os demais genótipos diferenciais foram ECW-10R, ECW 20-R e ECW 30-R, que contêm os genes $B s 1, B s 2$ e $B s 3$, respectivamente (Hibberd et al., 1987) e a pimenta $C$. pubescens PI-235047, contêm os gene Bs4 (Sahin \& Miller, 1996).

Os genótipos diferenciais utilizados são acessos do banco de germoplasma de Capsicum da Embrapa Hortaliças, onde estão depositados com a seguinte codificação CNPH 1375 (ECW), CNPH 3002 (ECW 10-R), CNPH 3001 (ECW 20-R) e CNPH 3005 (ECW 30-R) (Tabela 1).

O experimento foi conduzido em uma sala de crescimento, com luminosidade e temperatura controladas estabelecidas para fotoperíodo de $12 \mathrm{~h} / 12 \mathrm{~h}$ (luz/escuro) a $28^{\circ} \mathrm{C}$.

\section{Testes de inoculação nos genótipos diferenciais}

Foram caracterizados quanto à raça 67 isolados, identificados como da espécie $X$. euvesicatoria, sendo 13 do Ceará, 4 da Bahia, 1 do Sergipe, 2 do Pernambuco, 4 do Amazonas, 
1 da Roraima, 1 do Pará, 22 do Distrito Federal, 5 do Goiás, 3 do Espírito Santo, 3 de São Paulo e 8 de Minas Gerais (Tabela 2). Foi incluído como controle o isolado UENF 4135, cedido pela Universidade Norte Fluminense, previamente identificado como raça P3. Após recuperados do tampão de preservação os isolados foram repicados para placas de Petri contendo meio AN, por um período de $48 \mathrm{~h}$ a $28^{\circ} \mathrm{C}$. Após esse período, preparou-se uma suspensão bacteriana em sulfato de magnésio $(10 \mathrm{mMol} / \mathrm{L})$ com concentração aproximada de $5 \times 10^{8} \mathrm{UFC} / \mathrm{ml}$, ajustada em espectrofotômetro $\left(\mathrm{OD}_{600 \mathrm{~nm}}=0,3\right)$. Com o auxilio de uma seringa, as plantas foram infiltradas na face adaxial da folha, sendo utilizada uma folha por isolado (duas infiltrações por folha) (Figura 1A). Na ocasião as plantas apresentavam 6-7 folhas verdadeiras. Para tanto foram cultivadas em bandeja de poliestireno contendo substrato comercial Plantmax e plantadas em vasos de 0,5 L contendo uma mistura de solo no estádio de 2-3 folhas verdadeiras.

A determinação das raças foi feita com base nos sintomas de suscetibilidade ou resistência (reação de hipersensibilidade) (Figura 1B). As plantas foram observadas periodicamente, atentando-se para realizar a avaliação da ocorrência da reação de hipersensibilidade aos 12, 24 e 36 horas após a infiltração (Sahin \& Miller, 1996; Mariano, 2000; Romeiro, 2000; Romero et al., 2002). Já para observar a reação de suscetibilidade, a avaliação foi realizada com 48 e 72 horas após a infiltração. 


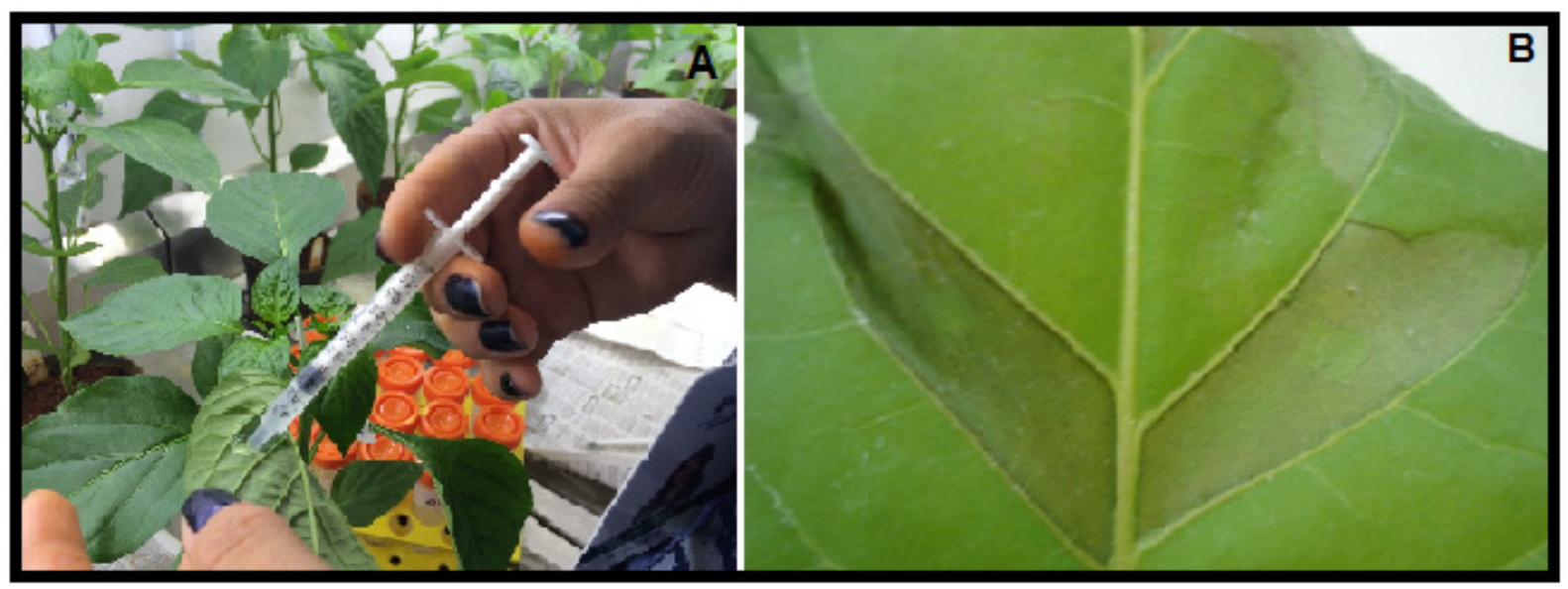

Figura 1. A- Inoculação por infiltração em folhas de pimentão. B- Reação de hipersensibilidade a Xanthomonas euvesicatoria em folha de pimentão por um isolado incompatível.

Tabela 1. Reação de genótipos diferenciadores às 11 raças de Xanthomonas euvesicatoria associadas à manchabacteriana em Capsicum e genes avr e Hrp bacterianos,associados ao gene de resistência ao patógeno. (Adaptado de Jones, 1998).

\begin{tabular}{|c|c|c|c|c|c|}
\hline \multirow{3}{*}{ Raças / Genes avr ${ }^{1}$} & \multicolumn{5}{|c|}{ Genótipos / Genes de resistência $^{2}$} \\
\hline & $\begin{array}{c}\text { ECW } \\
(\mathrm{CNPH} 1375)^{*}\end{array}$ & $\begin{array}{c}\text { ECW-10R } \\
(\mathrm{CNPH} 3002)^{*}\end{array}$ & $\begin{array}{c}\text { ECW-20R } \\
\text { (CNPH 3001)* }\end{array}$ & $\begin{array}{c}\text { ECW-30R } \\
(\mathrm{CNPH} 3005)^{*}\end{array}$ & PI-235047 \\
\hline & & $(B s 1)$ & $(B s 2)$ & $(B s 3)$ & $(B s 4)$ \\
\hline $\mathbf{0}(a v r B S 1, a v r B s 2, a v r B s 3, a v r B s 4)$ & $\mathrm{S}^{3}$ & $\mathrm{RH}^{3}$ & $\mathrm{RH}$ & RH & $\mathrm{RH}$ \\
\hline $1(a v r B s 2, a v r B s 3$, avrBs 4$)$ & S & $\mathrm{S}$ & RH & RH & RH \\
\hline $2(a v r B s 1, a v r B s 2)$ & S & RH & RH & S & S \\
\hline $3(a v r B s 2, a v r B s 4)$ & $S$ & $S$ & RH & $S$ & RH \\
\hline $4(a v r B s 3, a v r B s 4)$ & $\mathrm{S}$ & $\mathrm{S}$ & $S$ & RH & RH \\
\hline $5(a v r B s l)$ & S & RH & $S$ & S & S \\
\hline $6(a v r B s 4)$ & S & S & S & S & RH \\
\hline $7(a v r B s 2, a v r B s 3)$ & $S$ & $S$ & RH & RH & $S$ \\
\hline $8(a v r B s 2)$ & $S$ & S & RH & S & $S$ \\
\hline $9(a v r B s 3)$ & $S$ & S & $S$ & $\mathrm{RH}$ & $S$ \\
\hline 10 nenhum gene $a v r$ conhecido & $S$ & S & $S$ & S & $S$ \\
\hline
\end{tabular}

1- Genes de avirulência entre parênteses;

2- Genes de resistência entre parênteses;

3- S=Suscetibilidade (reação compatível) / RH= Reação de hipersensibilidade (reação incompatível);

*Numeração de acessos do banco de germoplasma de Capsicum da Embrapa Hortaliças. 


\section{RESULTADOS}

\section{Identificação molecular de espécies}

A partir da análise dos perfis BOX-PCR, fragmentos de DNA amplificados com iniciadores específicos e a constatação da presença do gene avrRxv, identificou-se 71 isolados como Xanthomonas euvesicatoria (Figura 3B, 4B e C e 5). Apenas quatro isolados foram identificados como Xanthomonas gardneri, os quais foram coletados nos estados do Espírito Santo, São Paulo e Minas Gerais (Figura 3A, 4A, 5 e Tabela 2).

Um isolado, o 124-P obtido de amostras de folhas coletadas em lavouras de pimentão em Ubajara, CE e recebidas no Laboratório de Fitopatologia da Embrapa Hortaliças em 2014, foi identificado como $X$. perforans por meio de PCR-multiplex (Araújo, 2012). As folhas apresentavam perfurações (Figura 2) como os sintomas típicos desta espécie observados em folhas de tomateiro (Quezado-Duval \& Lopes, 2010).

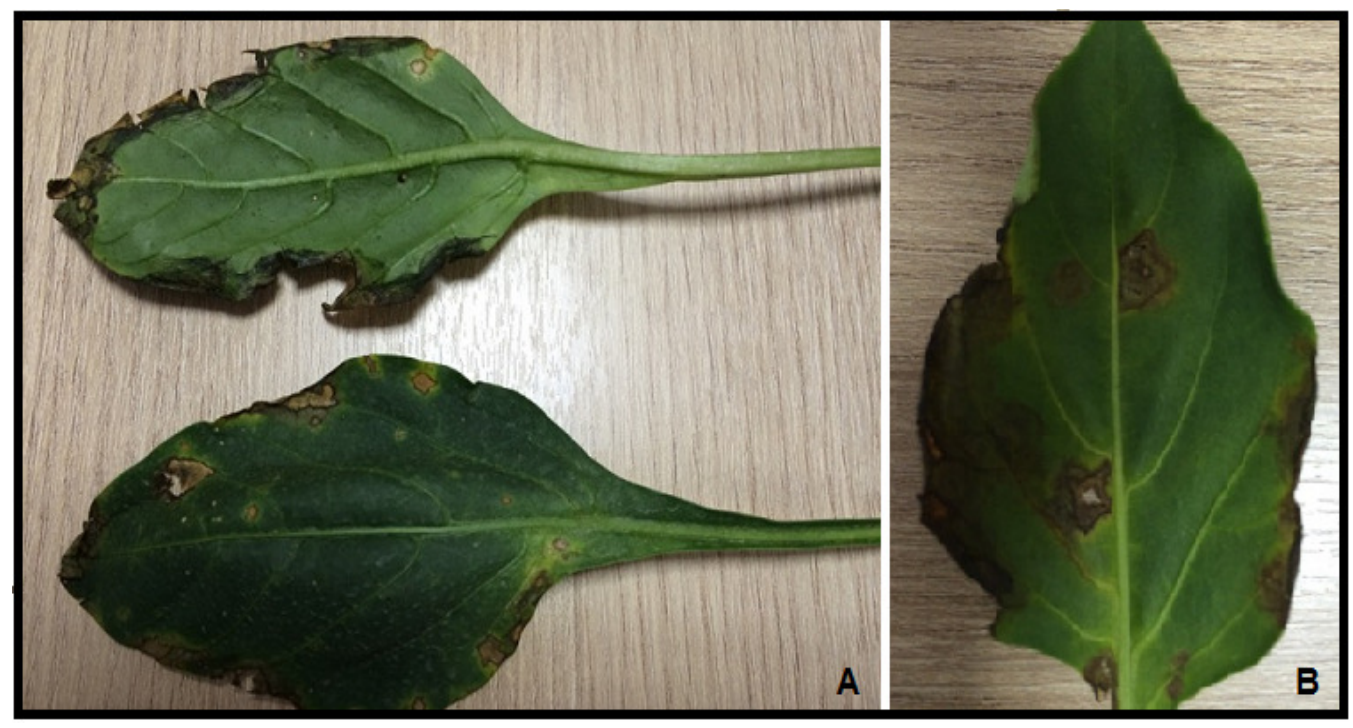

Figura 2. Sintomas da mancha-bacteriana em folhas de pimentão. A e B- Perfurações causadas pela espécie Xanthomonas perforans. Foto: Alice Quezado. 


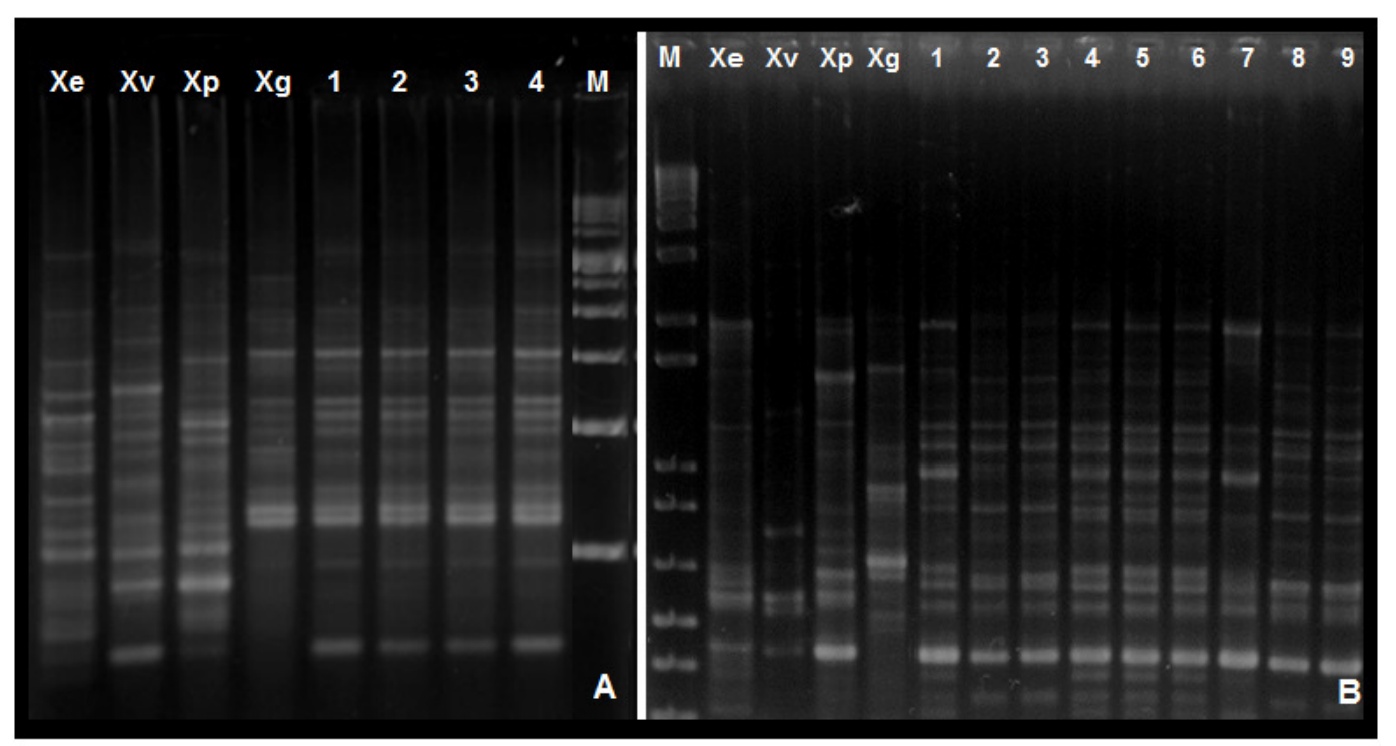

Figura. 3. Perfil BOX-PCR de isolados de Xanthomonas spp causadoras de mancha-bacteriana em plantas do gênero Capsicum em gel de agarose (1,5\%) (A e B) . Xe, Xv, Xp e Xg são isolados de referência de $X$. euvesicatoria (IBSBF 2363), X. vesicatoria (IBSBF 2364) $X$. perforans (IBSBF 2370) e X. gardneri (IBSBF 2373), respectivamente. $\mathrm{M}=$ marcador $1 \mathrm{~kb}$ plus DNA ladder (A e B). A- Isolados caracterizados como X gardneri: de 1 a 4; B - Isolados caracterizados como X. euvesicatoria: 1 a 9 .

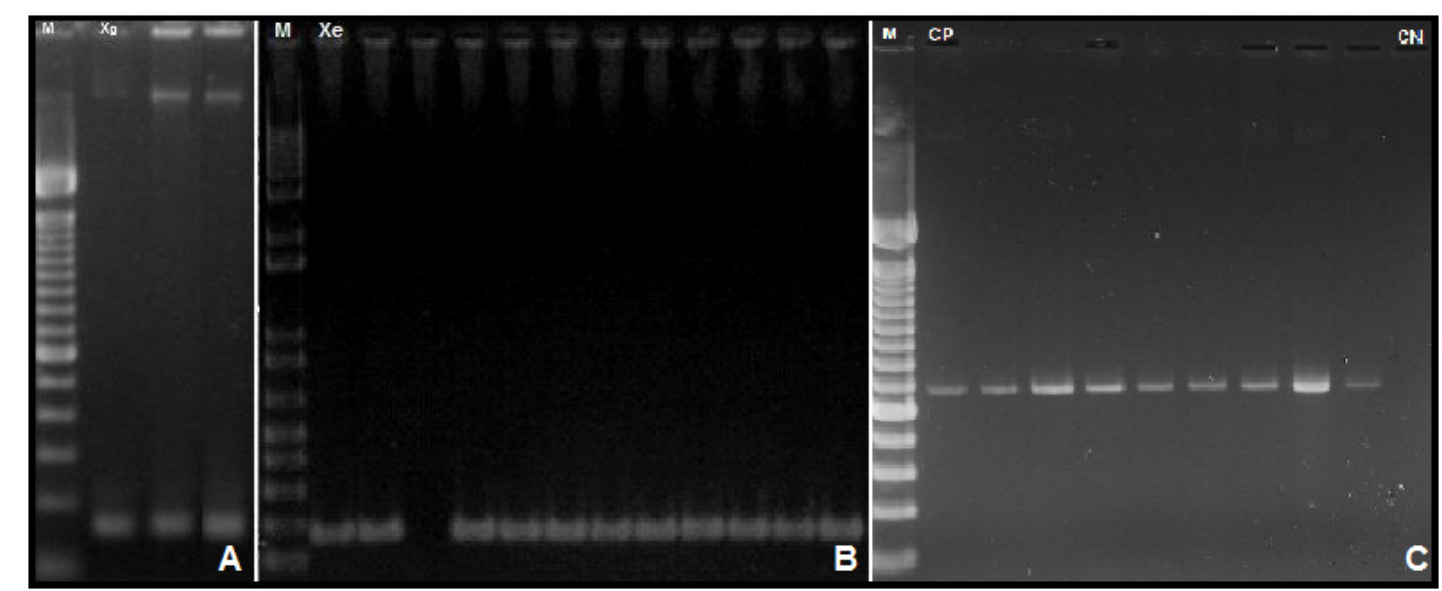

Figura 4. Eletroforese em gel de agarose (1,5\%), dos produtos de PCR obtidos com iniciadores específicos. A- Fragmentos correspondenetes ao iniciador específico de Xanthomonas gardneri (154pb); B- Fragmentos correspondentes ao iniciador específico de X. euvesicatoria (173pb); CFragmentos de $680 \mathrm{pb}$ correspondentes ao gene $a v r R x v$, relacionado a hipersensibilidade em tomateiro e característico da espécie Xanthomonas euvesicatoria. $\mathrm{M}=$ marcador $1 \mathrm{~kb}$ plus DNA ladder. $\mathrm{CP}=$ controle positivo da espécie. $\mathrm{CN}=$ controle negativo água. 


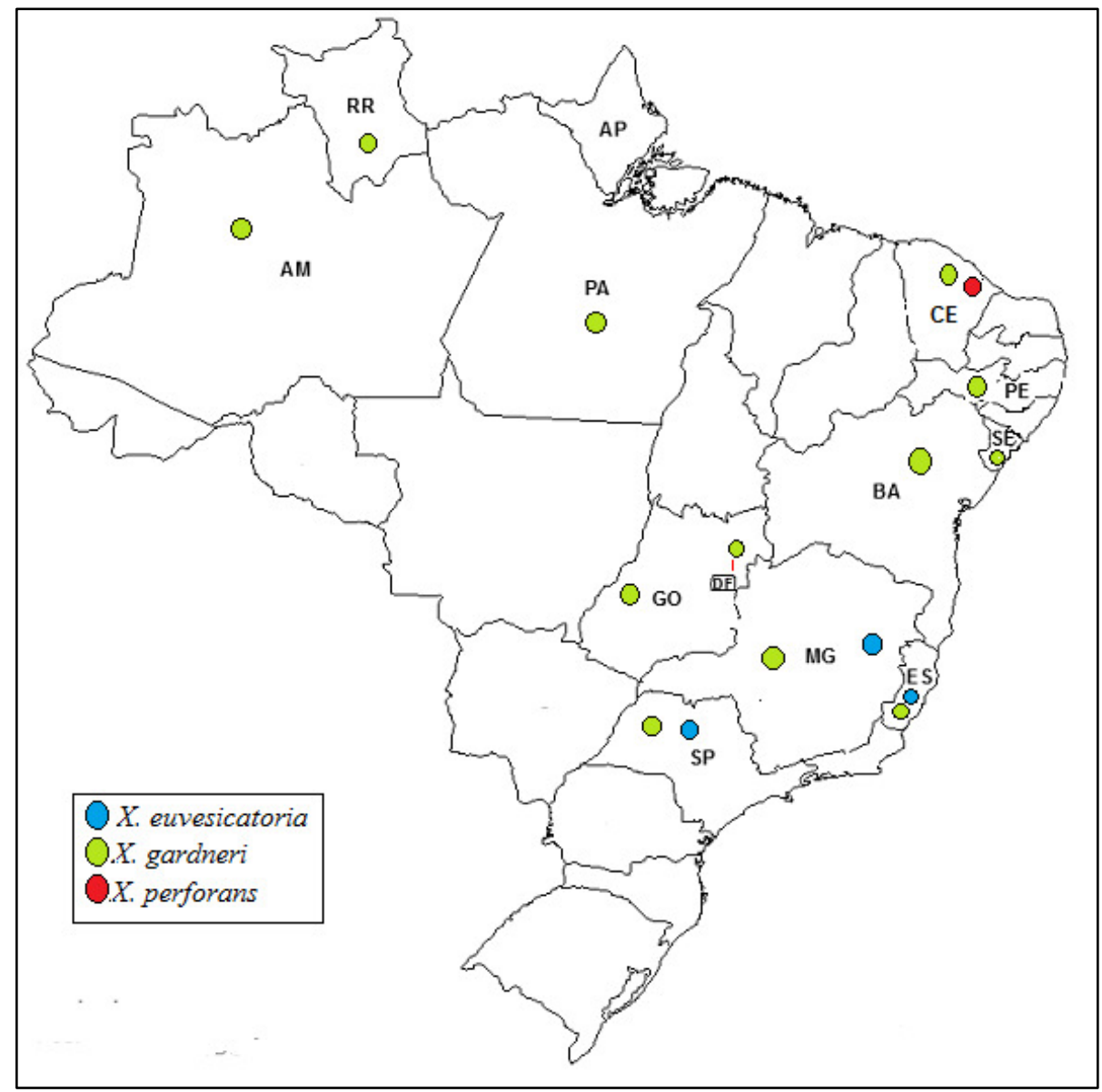

Figura 5. Distribuição das espécies dos 76 isolados de Xanthomonas spp. coletados em onze estados brasileiros mais o Distrito Federal.

\section{Caracterização das raças}

Foram observadas as seguintes raças entre os isolados de $X$. euvesicatoria coletados por estado: Ceará - raças 5, 0, 3 ou 8, 6 ou 10 e 4 ou 9; Bahia - raças 3 ou 8, 4 ou 9 e 7; Pernambuco - raça 5, 6 ou 10; Sergipe - raça 0; Amazonas - raças 0, 3 ou 8 e 4 ou 9; Roraima - raça 6 ou 10; Pará - raça 5; Goiás - raças 5, 4 ou 9 e 1 ou 7; Distrito Federal - raças 0, 5, 3 ou 8, 4 ou 9 e 6 ou 10; Minas Gerais - raças 0, 5, 1 ou 7, 3 ou 8, 4 ou 9 e 6 ou 10; São Paulo - raças 1 ou 7, 2, 5 e 4 ou 9 e Espírito Santo - raça 4 ou 9 (Figura 6). Como não havia sementes da pimenta $C$. pubescens PI-235047 no banco de germoplasma de Capsicum da Embrapa Hortaliças que é uma 
linhagem utilizada para diferenciar as raças 1 da 7, 3 da 8, 4 da 9 e 6 da 10, não foi possível determinar a raça exata a que pertence esses isolados.

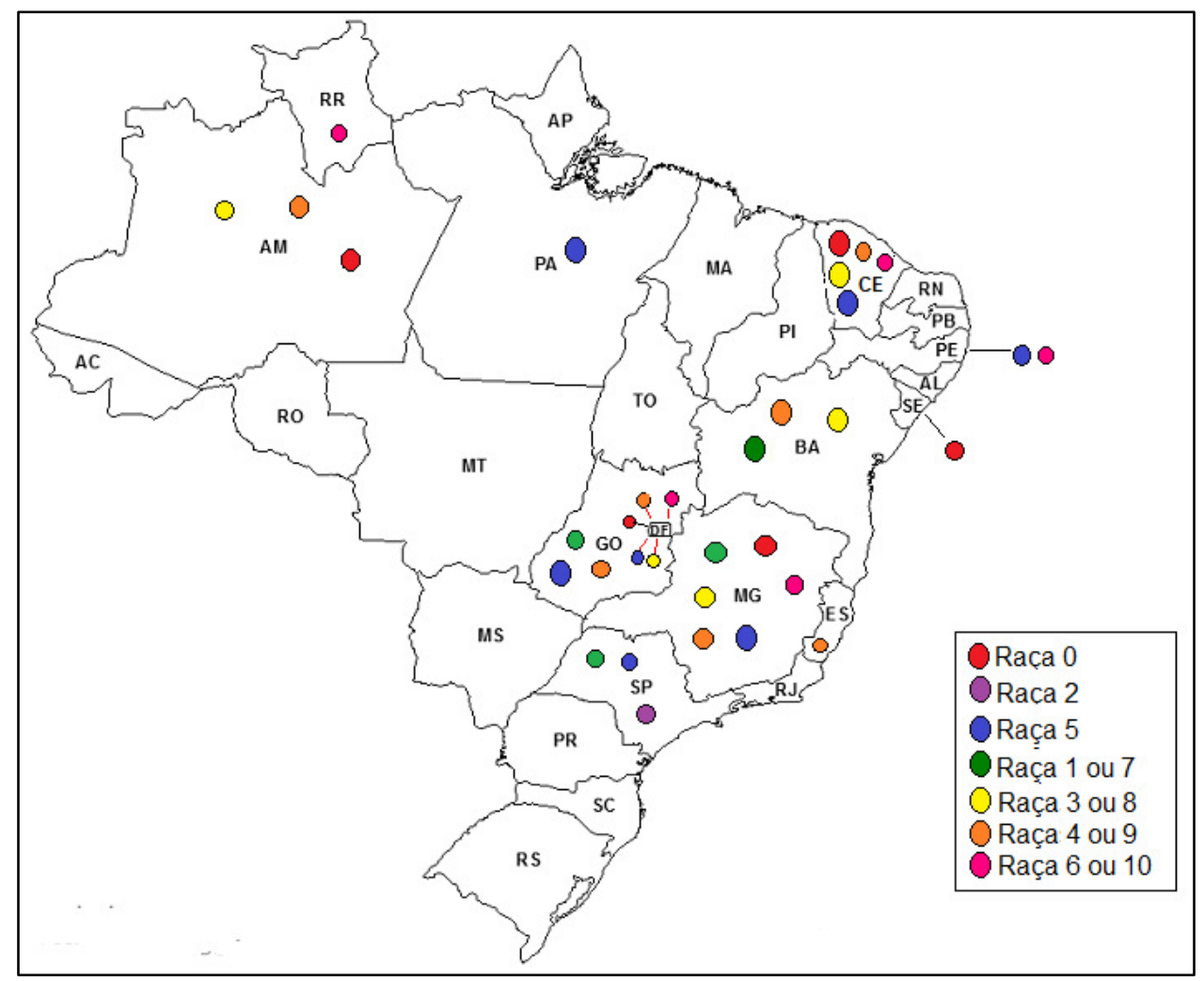

Figura 6. Distribuição das raças dos 67 isolados da espécie Xanthomonas euvesicatoria coletados em onze estados brasileiros mais o Distrito Federal.

De acordo com os resultados, a distribuição das raças fisiológicas identificadas, foi disposta por regiões conforme mostra a Tabela 3. 
Tabela 2. Hospedeira, cultivar, ano, local de coleta e identificação dos isolados brasileiros da coleção de Xanthomonas associadas ao gênero Capsicum spp. do Laboratório de Fitopatologia da Embrapa Hortaliças.

\begin{tabular}{|c|c|c|c|c|c|c|}
\hline Código & Hospedeira & Cultivar & Ano & Local & Espécie & Raças \\
\hline $3-\mathrm{P}$ & Pimenta & - & 1982 & Brasília - DF & X. euvesicatoria & 5 \\
\hline 4-P & Pimenta & - & 1982 & Brasília - DF & X. euvesicatoria & 5 \\
\hline $5-\mathrm{P}$ & Pimenta & - & 1983 & Brasília - DF & X. euvesicatoria & 5 \\
\hline 6-P & Pimenta & - & 1984 & Itabaiana - SE & X. euvesicatoria & 0 \\
\hline 8-P & Pimenta & - & 1984 & Camocim São Félix - PE & X. euvesicatoria & 6 ou 10 \\
\hline 9-P & Pimentão & - & 1984 & Vitória de Santo Antão - PE & X. euvesicatoria & 5 \\
\hline $11-\mathrm{P}$ & Pimentão & - & 1984 & Brasília - DF & X. euvesicatoria & 0 \\
\hline $15-\mathrm{P}$ & Pimentão & - & 1982 & Monte Mor - SP & X. euvesicatoria & $10 \mathrm{u} 7$ \\
\hline 16-P & Pimenta & - & 1991 & Manaus AM & X. euvesicatoria & 3 ou 8 \\
\hline $17-\mathrm{P}$ & Pimenta & - & 1991 & Manaus - AM & X. euvesicatoria & 4 ou 9 \\
\hline 20-P & Pimentão & - & 1995 & Botucatu - SP & X. euvesicatoria & 5 \\
\hline 24-P & Pimentão & Mallorca & 1997 & Brazilândia - MG & X. euvesicatoria & 0 \\
\hline 25-P & Pimentão & Mallorca & 1997 & Brazilândia - MG & X. euvesicatoria & 3 ou 8 \\
\hline 26-P & Pimentão & Mallorca & 1997 & Brazilândia - MG & X. euvesicatoria & 6 ou 10 \\
\hline 29-P & Pimentão & Mallorca & 1997 & Presidente Olegário - MG & X. euvesicatoria & 0 \\
\hline 30-P & Pimentão & Mallorca & 1997 & Presidente Olegário - MG & X. euvesicatoria & 0 \\
\hline 33-P & Pimentão & Mallorca & 1997 & Presidente Olegário - MG & X. euvesicatoria & 1 ou 7 \\
\hline $35-\mathrm{P}$ & Pimentão & Mallorca & 1997 & Presidente Olegário - MG & X. euvesicatoria & 4 ou 9 \\
\hline 36-P & Pimentão & - & 1998 & Juazeiro - BA & X. euvesicatoria & 3 ou 8 \\
\hline 37-P & Pimentão & - & 1998 & Juazeiro - BA & X. euvesicatoria & 3 ou 8 \\
\hline 38-P & Pimenta & Cheiro* & 1999 & Tefé - AM & $X$. euvesicatoria & 3 ou 8 \\
\hline 39-P & Pimenta & Cheiro* & 1999 & Parintins - AM & X. euvesicatoria & 0 \\
\hline 40-P & Pimentão & Cascadura & 1999 & Alto Alegre Boa Vista - RR & X. euvesicatoria & 6 ou 10 \\
\hline 41-P & Pimentão & - & 1991 & Lins - SP & X. euvesicatoria & 2 \\
\hline 42-P & Pimenta & - & 2001 & Brasília -DF & X. euvesicatoria & - \\
\hline 43-P & Pimentão & Mallorca & 2002 & Brasilândia - MG & $X$. gardneri & - \\
\hline 49-P & Pimentão & - & 2002 & Formosa - GO & X. euvesicatoria & 1 ou 7 \\
\hline 50-P & Pimentão & - & 2002 & Brasília - DF ${ }^{1}$ & $X$. euvesicatoria & 6 ou 10 \\
\hline 51-P & Pimentão & Margarita & 2002 & Brasília - DF ${ }^{1}$ & X. euvesicatoria & 5 \\
\hline 55-P & Pimentão & - & 2003 & Belém - PA & X. euvesicatoria & 5 \\
\hline $58-\mathrm{P}$ & Pimentão & - & 2003 & Petrolina - GO & X. euvesicatoria & 5 \\
\hline 59-P & Pimentão & - & 2003 & Petrolina - GO & $X$. euvesicatoria & 5 \\
\hline $62-\mathrm{P}$ & Pimenta & Cheiro* & 2003 & Morrinhos - GO & X. euvesicatoria & 4 ou 9 \\
\hline 63-P & Pimenta & Cumari & 2003 & Morrinhos - GO & $X$. euvesicatoria & - \\
\hline 72-P & Pimenta & Cheiro* & 2009 & Gama - DF & X. euvesicatoria & 6 ou 10 \\
\hline 75-P & Pimentão & Cayenne & 2009 & Ceilândia - DF & X. euvesicatoria & - \\
\hline 77-P & Pimentão & Magali-R & 2009 & Araguari - MG & X. euvesicatoria & 5 \\
\hline 79-P & Pimentão & Magali-R & 2009 & Guaraciaba - CE & X. euvesicatoria & 5 \\
\hline 80-P & Pimentão & Safari & 2009 & Ubajara - CE & X. euvesicatoria & 4 ou 9 \\
\hline 81-P & Pimentão & Safari & 2009 & Ubajara - CE & X. euvesicatoria & 0 \\
\hline 83-P & Pimentão & Marta-R & 2009 & São Benedito - CE & X. euvesicatoria & 3 ou 8 \\
\hline 84-P & Pimentão & Marta-R & 2009 & São Benedito - CE & X. euvesicatoria & 3 ou 8 \\
\hline 85-P & Pimentão & Natali & 2009 & Ubajara - CE & X. euvesicatoria & 3 ou 8 \\
\hline 86-P & Pimenta & Cheiro* & 2009 & Tianguá - CE & X. euvesicatoria & 0 \\
\hline 87-P & Pimenta & Cheiro* & 2009 & Tianguá - CE & X. euvesicatoria & 0 \\
\hline
\end{tabular}




\begin{tabular}{|c|c|c|c|c|c|c|}
\hline 89-P & Pimentão & Dahra & 2009 & Tianguá - CE & X. euvesicatoria & 6 ou 10 \\
\hline $90-\mathrm{P}$ & Pimentão & Dahra & 2009 & Tianguá - CE & X. euvesicatoria & 6 ou 10 \\
\hline $92-\mathrm{P}$ & Pimentão & Magali-R & 2009 & Venda Nova do Imigrante - ES & X. euvesicatoria & 4 ou 9 \\
\hline 93-P & Pimentão & Magali-R & 2009 & Venda Nova do Imigrante - ES & X. euvesicatoria & 4 ou 9 \\
\hline 94-P & Pimentão & - & 2009 & São Benedito - CE & $X$. euvesicatoria & 6 ou 10 \\
\hline $95-\mathrm{P}$ & Pimentão & - & 2009 & São Benedito - CE & X. euvesicatoria & 5 \\
\hline 96-P & Pimentão & - & 2010 & Brazabantes - GO & X. euvesicatoria & 5 \\
\hline 98-P & Pimentão & Natali & 2011 & Jaguaquara - BA & X. euvesicatoria & 4 ou 9 \\
\hline 99-P & Pimentão & Natali & 2011 & Jaguaquara - BA & X. euvesicatoria & 1 ou 7 \\
\hline $100-\mathrm{P}$ & Pimentão & Dahra RX & 2011 & Brasília - DF & X. euvesicatoria & - \\
\hline $101-\mathrm{P}$ & Pimentão & Dahra RX & 2011 & Brasília - DF & X. euvesicatoria & 6 ou 10 \\
\hline $102-\mathrm{P}$ & Pimenta & - & 2011 & Brasília - DF ${ }^{3}$ & X. euvesicatoria & 4 ou 9 \\
\hline 103-P & Pimenta & - & 2011 & Brasília - $\mathrm{DF}^{3}$ & X. euvesicatoria & 4 ou 9 \\
\hline 104-P & Pimentão & Paloma & 2011 & Brasília - $\mathrm{DF}^{3}$ & X. euvesicatoria & 6 ou 10 \\
\hline $105-\mathrm{P}$ & Pimenta & Cheiro* & 2011 & Brasília - DF & X. euvesicatoria & 4 ou 9 \\
\hline 106-P & Pimentão & Margarita & 2011 & Alto Caxixe - ES & $X$. gardneri & \\
\hline 109-P & Pimentão & Margarita & 2011 & Alto Caxixe - ES & X. euvesicatoria & 4 ou 9 \\
\hline $110-\mathrm{P}$ & Pimentão & Dahra RX & 2011 & Brasília - DF & X. euvesicatoria & 4 ou 9 \\
\hline $111-\mathrm{P}$ & Pimentão & Dahra RX & 2011 & Brasília - DF & X. euvesicatoria & 4 ou 9 \\
\hline $112-\mathrm{P}$ & Pimentão & Dahra RX & 2011 & Brasília - DF ${ }^{3}$ & X. euvesicatoria & 4 ou 9 \\
\hline 113-P & Pimentão & Dahra RX & 2011 & Brasília - DF ${ }^{3}$ & X. euvesicatoria & 4 ou 9 \\
\hline $114-\mathrm{P}$ & Pimentão & Dahra RX & 2011 & Brasília - DF & X. euvesicatoria & 4 ou 9 \\
\hline $115-\mathrm{P}$ & Pimentão & Dahra RX & 2011 & Brasília - $\mathrm{DF}^{3}$ & X. euvesicatoria & 6 ou 10 \\
\hline $116-\mathrm{P}$ & Pimentão & Dahra RX & 2011 & Brasília - DF & X. euvesicatoria & 4 ou 9 \\
\hline 117-P & Pimentão & Paloma & 2011 & Brasília - DF ${ }^{3}$ & X. euvesicatoria & 6 ou 10 \\
\hline $118-\mathrm{P}$ & Pimentão & Paloma & 2011 & Brasília - $\mathrm{DF}^{3}$ & X. euvesicatoria & 4 ou 9 \\
\hline 119-P & Pimentão & - & 2011 & Capão Bonito - SP & $X$. gardneri & - \\
\hline 120-P & Pimentão & - & 2011 & Capão Bonito - SP & $X$. gardneri & - \\
\hline $122-\mathrm{P}$ & Pimenta & - & 2012 & Gama - DF & X. euvesicatoria & 3 ou 8 \\
\hline $123-\mathrm{P}$ & Pimentão & - & 2013 & Ubajara - CE & X. euvesicatoria & 4 ou 9 \\
\hline 124-P & Pimentão & Safari R & 2014 & Ubajara - CE & X. perforans & - \\
\hline
\end{tabular}

- : Não determinado.

${ }^{1}$ NR Taquara; ${ }^{2}$ NR São José; ${ }^{3}$ NR Rio Preto.

*Refere-se ao grupo de pimenta, não à variedade.

\section{DISCUSSÃO}

Existem poucos trabalhos que realizaram levantamentos das espécies de Xanthomonas associadas exclusivamente ao gênero Capsicum (Ignjatov et al., 2010; Lue et al., 2010; Areas et al., 2014; Kizheva et al., 2013). As espécies identificadas tendo pimentão como hospedeira foram: X. euvesicatoria de distribuição mundial (Jones et al., 2005; Lue et al., 2010; Areas et al., 2012; Kizheva et al., 2013), X. gardneri, com relatos de ocorrência na Costa Rica (Jones et 
al., 2000), X. perforans relatada, na Flórida, EUA (Bart el al., 2012) e X. vesicatoria na Bulgária e na Macedônia (Kizheva et al., 2013). No Brasil, Wierzbicki (2004) trabalhou com isolados de São Paulo, tratado na época como X. campestris pv. vesicatoria, enquanto Areas et al. (2014), com 59 isolados, a maioria obtidos no estado de São Paulo, utilizaram a diferenciação atual das espécies por meio dos iniciadores específicos de Koenraadt et al. (2009), encontrando apenas $X$. euvesicatoria, assim como Lue et al. (2010) em Taiwan.

No presente estudo, a espécie $X$. euvesicatoria foi a que predominou, mas registrou-se também a ocorrência de $X$. gardneri e de X. perforans. Assim, X. euvesicatoria parece, portanto, ser a espécie mais adaptada ao gênero Capsicum até o momento. Vale ressaltar que este é o primeiro relato da ocorrência de infecção natural de $X$. gardneri e de $X$. perforans em pimentão no Brasil.

Em estudos realizados no Brasil sobre a ocorrência de espécies de Xanthomonas associadas à mancha-bacteriana do tomateiro, há relatos das quatro espécies de Xanthomonas (X. euvesicatoria, X. vesicatoria, X. gardneri e X. perforans), tanto para o segmento para mesa, quanto para processamento industrial (Costa et al., 2012; Quezado-Duval et al., 2005; QuezadoDuval et al., 2010; Pereira et al., 2011).

Em relação à predominância das espécies para o tomateiro, estudos demonstram que a espécie $X$. perforans está predominando em lavouras de tomate para processamento industrial (Quezado-Duval et al., 2013; Araújo, 2011) e tem ocorrido com frequência levemente superior a X. gardneri em lavouras de mesa (Pereira, 2010; Quezado-Duval et al. 2014) ou inferior a esta última na região do Alto Vale do Rio do Peixe, em Santa Catarina (Costa et al., 2012).

A competitividade entre as espécies de Xanthomonas, como citado por Araújo et al. (2012), pode auxiliar no entendimento da prevalência de uma sobre as outras em determinada região. A predominância de $X$. perforans no tomateiro, por exemplo, pode ser devido a vantagem 
competitiva sobre as demais, pela produção de bacteriocina, como relatado para X. euvesicatoria (Jones et al., 1998), ou pela adaptabilidade térmica (Araújo et al., 2011), tornando-se dessa forma a espécie prevalente em determinadas regiões brasileiras.

De acordo com Quezado-Duval (2003), que analisou isolados de tomate para processamento industrial no Brasil, membros de X. gardneri apresentaram virulência variável. Alguns isolados foram virulentos às plantas de tomate e pimentão e outros somente às plantas de tomate, tendo sido encontrados na Costa Rica isolados virulentos somente às plantas de pimentão (Bouzar et al, 1999; Quezado-Duval, 2003; Potnis et al., 2015). Xanthomonas gardneri era tratada como uma espécie de ocorrência esporádica (Jones et al., 2000), porém o relato dessa espécie infectando naturalmente pimentão, pode ser um indicativo de que esta se tornando um componente importante para culturas de pimentão no Brasil.

A ocorrência de quatro isolados de Xanthomonas gardneri coletados nos estados Espírito Santo (região serrana), São Paulo e Minas Gerais pode estar relacionada com a melhor adaptabilidade dessa espécie a temperaturas mais amenas (Araújo et al., 2011). Por outro lado, apesar de $X$. perforans ter sido associada a maior adaptabilidade a temperaturas elevadas (Araújo et al., 2011), sua detecção em Capsicum ocorreu também em região serrana, mas no estado do Ceará. Apenas um levantamento continuado poderá indicar se a espécie irá se estabelecer em regiões de climas mais amenos nos próximos anos.

A análise de regiões repetitivas por meio de amplificação por PCR (REP-PCR) vem sendo muito utilizada nos estudos de diversidade genética, que são métodos rápidos e altamente reprodutíveis para a caracterização de bactérias fitopatogênicas (Lows et al., 1994; Pereira et al., 2011; Costa et al., 2012). Bouzar et al. (1999) utilizaram rep-PCR (PCR repetitivo) em isolados de Xanthomonas spp. causadoras da mancha-bacteriana no Caribe e América Central, revelando a presença de quatro grupos distintos (A-D), encontrando a predominância de isolados do grupo 
A (X. axonopodis pv. vesicatoria, atualmente X. euvesicatoria) Cuppels et al. (2006) também utilizaram rep-PCR para comparar isolados de Xanthomonas gardneri de diferentes locais, concluindo que todos os isolados apresentavam padrões iguais de rep-PCR.

O uso de iniciadores específicos permitiu a confirmação da identificação das espécies $X$. euvesicatoria e X. gardneri por BOX-PCR, com exceção do isolado de X. perforans não caracterizado quanto ao perfil por BOX-PCR por ter sido inserido ao final do estudo.

A amplificação do fragmento 680pb contendo o gene avrRxv, como esperado, foi observada em todos os isolados de X. euvesicatoria, indicando não ter havido inserção ou deleção no gene original. A expressão desse gene resulta em uma reação de hipersensibilidade (Jones \& Scott, 1986) no genótipo de tomate Hawaii 7998 (Wang et al., 1994; Yu et al., 1995), portador do gene $R x v 3$, caracterizando o isolado como raça T1 em relação a patossistema Xanthomonas-tomateiro (Whalen et al., 1988; Whalen et al., 1993). Não foi detectada amplificação dos isolados identificados como Xanthomonas gardneri, o que permitiria a esses isolados suplantar a resistência conferida pelo Hawaii 7998.

Em relação às raças de $X$. evesicatoria, no Brasil já foram observadas as raças $0,1,2,3,7$ e 8 em lavouras de pimentão em São Paulo, com predominância das raças 2 e 8 (Kobori \& Wierzbiki, 2000; Wierzbiki, 2004). Assim como constatado por Wierzbiki (2004), a presença das raças 2 e 8 , bem como a raça 7 , foi observada a partir de amostra sintomática de planta de tomate provenientes de lavouras para processamento industrial,na região Nordeste e no BrasilCentral, respectivamente (Quezado-Duval, 2003). Fora do Brasil, foi relatada a ocorrência das raças 0, 1 e 3 no Caribe e América Central (Bouzar et al., 1994). A raça 4 foi encontrada apenas nos Estados Unidos (Carolina do Norte e Flórida), México, Austrália, Caribe e América Central. $\mathrm{Na}$ Itália, foram encontrados as raças 1, 2 e 3 (Buonario, 1994). O'Garro et al. (1999), caracterizaram as raças de 404 isolados de Xanthomonas campestris pv.vesicatoria, obtidos a partir de pimentas da espécie $C$. chinense, cultivadas em Barbados e Granada. As raças 
predominantes em Granada foram 4, 5 e 6 e em Barbados 0, 1, 4 e 6. Mitrev \& Kovacvic (2006), caracterizaram as raças de isolados provenientes de pimentões e concluíram que as raças que predominam na Macedônia são as raças 0 e 2 .

Muitos trabalhos realizados com o gênero Xanthomonas em pimentão atestam a predominância das raças 1 (avrBs2, avrBs3, avrBs4) e 3 (avrBs2, avrBs4) no campo em outras regiões estudadas fora do Brasil (Bouzar et al., 1994; Bounario et al., 1994; Lee \& Cho, 1996; Sahin \& Miller, 1996). No presente trabalho a raça 1 ou 7 foi encontrada no estado da Bahia, Goiás, São Paulo e Minas Gerais, a raça 3 ou 8 no estado do Ceará, Bahia, Amazonas, Minas Gerais e em campo experimental na Embrapa Hortaliças em Brasília, DF. O fato de várias raças terem sido encontradas indica haver no país grande variabilidade genética na espécie $X$. euvesicatoria. A presença das raças 4 (avrBs3, avrBs4) ou 9 (avrBs3), seguida da raça 6 (avrBs4) ou 10 (nenhum gene avr conhecido), com capacidade de suplantar a resistência de uma das novas variedades disponíveis no mercado brasileiro, como a Dhara RX (Sakata) resistente as raças $0,1,2,3,7$ e 8 (Sakata, 2014), indica que uma resistência de efeito mais amplo, como a conferida pelos genes recessivos $b s 5$ e bs6, deva ser utilizada no desenvolvimento e disponibilização de variedades para o Brasil. A diversidade dessa espécie em termos de perfis genômicos (pela técnica de campo pulsado, PFGE) foi verificada em isolados obtidos no Nordeste em lavouras de tomate para processamento industrial, maior do que a encontrada para as demais espécies encontradas no estudo (Quezado-Duval et al., 2004).

A identificação dos isolados realizada por meio da inoculação na série diferencial permitiu a classificação dos isolados de Xanthomonas euvesicatoria em nível de raças. Neste caso, o conhecimento da relação gene-a-gene proposta por Flor (1942) contribuiu para a identificação através da expressão dos genes correspondentes de avirulência do patógeno e de hipersensibilidade do hospedeiro. 
O acesso da pimenta Capsicum pubescens (PI-235047) foi posteriormente incluído para a definição de raças de Xanthomonas de Capsicum (Sahin \& Miller, 1998), pois a raça 1 pode na verdade ser classificada como raça 7 , a raça 3 como raça 8 , a raça 4 como raça 9 e a raça 6 como raça 10. De fato, a inclusão desse novo genótipo não representa um ganho em resistência a todas as raças já identificadas, de modo que a utilização em programas de melhoramento não se torna atrativa.

Existe uma alta variabilidade ao grupo de Xanthomonas que ataca Capsicum, pois a quebra de resistência pelo patógeno ocorre principalmente devido à alta taxa de mutação dos genes avrBs1, avrBs2 e avrBs3 (Jones et al., 1998; Dahlbeck \&Stall, 1979; Swords et al., 1996; Minsavage et al., 1990). A maioria desses genes de avirulência estão presentes no plasmídeo e podem ser trocados por conjugação entre estirpes, com isso, as raças resultantes não são necessariamente estáveis (Canteros et al., 1995). De acordo os resultados obtidos no presente estudo, não havia ocorrência das raças 4 ou 9, 6 ou 10 associadas ao gênero Capsicum no Brasil, o que pode significar um evento de introdução relativamente recente que pode ter ocorrido via introdução de semente exótica infectada, ou por mutação em isolados de populações já estabelecidas no país, pois a raça 3 poderia transformar-se em raça 6 pela a perda no gene $a v r B s 2$ ou de sua funcionalidade (por deleção ou inserção de bases), a raça 1 poderia se transformar na raça 4 pela perda do gene $a v r B s 2$, que são genes localizados em plasmídeo, conforme comentado anteriormente. As principais cultivares plantadas no Brasil não têm resistência à $X$. euvesicatoria, o que favoreceria mutações ao acaso no campo, não favorecidas por pressão de seleção exercida pelo hospedeiro.

Com base resultados do presente estudo, foi possível definir parcialmente à qual raça cada isolado estudado pertence. Ressalta-se ainda que, para as variedades Dahra RX (Sakata), Commandant (Syngenta) e Paloma (Horticeres) são especificadas nos respectivos catálogo virtuais das empresas, as raças para qual a variedade é resistente. Já para a variedade Impacto 
(Seminis), isso não ocorre até o presente. Assim, estudos sobre o desempenho das variedades com resistência a Xanthomonas sp. associada à mancha-bacteriana, disponíveis no mercado brasileiro de sementes, são desejáveis para verificar a estabilidade dessa resistência e a necessidade de desenvolvimento de novas variedades.

\section{CONCLUSÕES}

De acordo com os resultados e alguns trabalhos com identificação de espécies associadas à mancha-bacteriana em Capsicum no Brasil, pode-se afirmar a prevalência da espécie Xanthomonas euvesicatoria ocorrendo em campos de produção de pimenta e pimentão. O entendimento das espécies causadoras da mancha-bacteriana associadas ao gênero Capsicum no Brasil é o primeiro passo para o direcionamento de estudos que visem à aquisição de um melhor nível de controle da doença no campo, utilizando a ferramenta resistência varietal.

Considera-se que o presente estudo faz o primeiro relato da ocorrência das espécies $X$. gardneri e $X$. perforans e de raças de $X$. euvesicatoria distintas das até então relatadas infectando naturalmente campos de produção comercial de pimentão no país. 


\section{REFERÊNCIAS BIBLIOGRÁFICAS}

ARAÚJO, E.R.; COSTA, J.R.; FERREIRA, M.A.S.V.; QUEZADO-DUVAL, A.M. 2012. Simultaneous detection and identification of the Xanthomonas species complex associated with tomato bacterial spot using species-specific primers and multiplex PCR. Journal of Applied Microbiology 113(6):1479-1490.

ARAÚJO, E. R.; PEREIRA, R. C; FERREIRA, M. A. S. V.; QUEZADO-DUVAL, A. M.; CAFÉ-FILHO, A. C. 2012. Sensitivity of xanthomonads causing tomato bacterial spot to copper and streptomycin and in vivo infra-specific competitive ability in Xanthomonas perforans resistant and sensitive to copper. Journal of Plant Pathology 94:79-87.

ARAÚJO, E. R.; PEREIRA, R. C.; FERREIRA, M. A. S. V.; CAFÉ-FILHO, A. C.; MOITA, A. W.; QUEZADO-DUVAL, A. M. 2011. Effect of temperature on pathogenicity components of tomato bacterial spot and competition between Xanthomonas perforans and X. gardneri. Acta Horticulturae, The Hague 914:39-42.

ARAÚJO, E.R.; COSTA, J.R.; PONTES, N.C.; FERREIRA, M.A.S.V.; QUEZADO-DUVAL, A.M. 2011. Prevalence of Xanthomonas perforans associated with bacterial spot in processing tomato crops in Brazil, Tropical Plant Pathology, v. 36, p.130. Suplemento. $44^{\circ}$ Congresso Brasileiro de Fitopatologia-Bento Gonçalves RS.

AREAS, M.S.; GONÇALVES, R.M.; SOMAN, J.M.; SAKATE, R.K.; GIORIA, R.; SILVA JÚNIOR, T.A.F.; MARINGONI, A. C. 2014. Prevalence of Xanthomonas euvesicatoria on pepper in Brazil. Journal of Phytopathology, p.1-5.

BART, R.; SHARLACH, M.; KASSEN, A.; POTNIS, N.; MINSAVAGE, G. V.; STASKAWICZ, B. J.; JONES, J. B. 2012. How high-throughput sequencing technology helps our understanding of plant-pathogenic bacteria (ouverview). APS Annual Meeting. Providence, RI. 
BOUZAR, H.; JONES, J.B.; STALL, R.E.; SOMODI, G.C., KELLY, R.O.; DAOUZLI, N. 1994a. Phenotypic characterization of Xanthomonas campestris pv. vesicatoria strains from the Caribbean and Central America. Phytopathology 84:1069.

BOUZAR, H.; JONES, J.B., MINSAVAGE, G.V., STALL, R.E.; SCOTT, J.W. 1994b. Proteins unique to phenotypically distinct groups of Xanthomonas campestris pv. vesicatoria revealed by silver staining. Phytopathology 84:39-44.

BOUZAR, H.; JONES, J.B; STALL, R.E.; HODGE, N.C.; MINSAVAGE, G.V.; BENEDICT, A.A.; ALVAREZ, A.M. 1994c. Physiological, chemical, serological, and pathogenic analyses of a worldwide collection of Xanthomonas campestris pv. vesicatoria strains. Phytopathology 84(7):663-671.

BOUZAR, H.; JONES, J.B.; STALL, R.E.; LOUWS, F.J.; SCHNEIDER, M.; RADEMAKER, J.L.W.; DE BRUIJN, F.J.; JACKSON, L.E. 1999. Multiphasic analysis of Xanthomonas causing bacterial spot disease on tomato and pepper in the Canbbean and Central America: Evidence for common lineages within and between countries. Phytopathology 89:28335.

BUONARIO, R.; STRAVATO, V.M.; SCORTHICHINI, M. 1994. Characterization of Xanthomonas campestris pv. vesicatoria from Capsicum annum L. In Italy. Plant Disease 78(3):296-299.

CANTEROS, B.I.; MINSAVAGEM, G.V.; JONES, J.B.; STALL, R.E. 1995. Diversity of plasmid in Xanthomonas campestris pv. vesicatoria. Phytopathology 85:1260-1265.

CANTEROS, B.I.; MINSAVAGEM, G. V.; BONAS, V.; PRING, D.; STALL, R.E. 1991. A gene from Xanthomonas campestris pv. vesicatoria that determines avirulence in tomato is related to avrBS3. Molecular and Plant-Microbe Interactions 4(6):628-632.

COOK, A.A. 1973 Characterization of hypersensitivity in Capsicum annuum induced by the tomato estirpe of Xanthomonas vesicatoria. Phytopathology 63:1260-1265. 
COSTA, J.R.; ARAÚJO, E.R.; BECKER, W.F.; FERREIRA, M.A.S.V.; QUEZADO-DUVAL, A.M. 2012. Ocorrência e caracterização do complexo de espécies causadoras da manchabacteriana do tomateiro no Alto Vale do Rio do Peixe, SC. Tropical Plant Pathology 37:149-154.

CUPPELS, D. A.; LOUWS, F. J.; AINSWORTH, T. 2006. Development and evaluation of PCRbased diagnostic assays for the bacterial speck and bacterial spot pathogens of tomato. Plant Disease 90:451-458.

DAHLBECK, D.; STALL, R.E. 1979. Mutations for change of race in cultures of Xanthomonas vesicatoria. Phytopathology 69:634.

GOODMAN, R.N.; NOVAKY, A. 1994. The hypersensitive reaction in plants to pathogens: a resistance phenomenon. St. Paul: APS Press, 244p.

GOPALAN, S.; YANG HE, S. 1996. Bacterial genes involved in the elicitation of hypersensitive response and pathogenesis. Plant Disease 80:604-610.

HIBBERD, A. M.; STALL, R. E.; BASSET, M. J. 1987. Different phenotypes associated with incompatible races and resistance genes in bacterial spot disease of pepper. Plant Disease, 71:1075-1078.

IGNJATOV, M.; GASIC, K..; IVANOVIC, M.; Milan SEVIC, M..; OBRADOVIC, A.; MILOSEVIC, M. 2010. Karakterizacija sojeva Xanthomonas euvesicatoria, patogena paprike u Srbiji. Naučni rad: Scientific paper. Institut za ratarstvo i povrtarstvop. p.139-149.

JONES, J.B.; LACY, GH.; BOUZAR, H.; MINSAVAGE, G. V.; STALL, R.E.; SCHAAD, N.W. 2005. Bacterial spot - Worldwide distribution, importance and review. Acta Horticulturae 695:2733.

JONES, J.B. LACY, G.H.; BOUZAR, H.; STALL, R.E.; SCHAAD, N.W. 2004. Reclassification of the Xanthomonads associated with bacterial spot disease of tomato and pepper. Systematic and Applied Microbiology 27:755-762. 
JONES, J. B.; MINSAVAGE, G.V.; ROBERTS, P. D.; JOHNSON, R. R.; KOUSIK, C. S.; SUBRAMANIAN, S.; STALL, R. E. 2002. A non-hypersensitive in pepper to the bacterial spot pathogen is associated wift two recessive genes. Phytopathology 92:273-277.

JONES, J.B.; BOUZAR, H.; STALL, R.E.; ALMIRA, E.C.; ROBERT, P.D.; BOWEN, B.W.; SUDBERRY, J.; STRICKLER, P.M.; CHUN, J. 2000. Sytematic analysis of Xanthomonas (Xanthomonas spp.) associated whit pepper and tomato lesions. International Journal of Systematic and Evolutionary Microbiology 50:1211-1219.

JONES, A. L.; JONES, J.P.; SOMODI, GC.; STALL, R. E.; PERNEZNY, K.; ELMORSY, G.; SCOTT, J.W. 1998. Evidence for the preemptive nature of tomato race 3 of Xanthomonas campestris pv. vesicatoria in Florida. Phypathology 88:33-38.

JONES, J.B.; STALL, R.E.; BOUZAR, H. 1998. Diversity among Xanthomonads pathogenic on pepper and tomato. Annual Review of Phytopalogy 36:41-58.

JONES, J.B.; SCOTT, J.W. 1986. Hypersensitive response in tomato to Xanthomonas campestris pv. vesicatoria. Plant Disease 70(4):337-339.

KIZHEVA, Y.; VANCHEVA, T.; HRISTOVA, P.; STOYANOVA, M.; STOJANOVSKA, M.; MONCHEVA, P.; BOGATZEVSKA, N. 2013. Identification of Xanthomonas strains from tomato and pepper and their sensitivity to antibiotics and copper. Agricultural Academy 19:8082.

KLEMENT, Z. 1963. Rapid detection of the patogenicity of phytopatogenic Pseudomonads. Nature 199:299-300.

KOBORI, R. F.; WIERZBICKI, R. 2000. Identificação de raças de Xanthomonas vesicatoria em pimentão na região de Lins-SP. In: 23 Congresso Paulista de Fitopatogia, Campinas. Summa Phytopathogica, 26:130. 
KOENRAADT, H.; VAN BETTERAY, B.; GERMAIN, R.; HIDDINK, G.; JONES, J.B.; OOSTERHOF, J.; RIJLAARSDAM, A.; ROORDA, P.; WOULDT, B. 2009. Development of specific primers for the molecular detection of bacterial spot of pepper and tomato. Acta Horticulturae 808:99-102.

KOUSIK, C.S.; RITCHIE, D.F. 1999. Development of bacterial spot on near-Isogenic lines of bell pepper carrying gene pyramids composed of defeated major resistance genes. Phytopathology 89(11):1066-1072.

LINDREN, P.B.; PEET, R.C.; PANOPOULOS, N.J. 1986. Gene-cluster of Pseudomonas syringae py. phaseolicola controls pathogenicity of bean and hypersensitivity on non host plants. Journal of Bacteriology 168:512.

LOPES, C.A.; QUEZADO-DUVAL, A.M. 2007. Epidemiologia e controle das bacterioses das hortaliças. In: ZAMBOLIM, L.; LOPES, C.A.; PICANÇO, M.C.; COSTA, H. (Orgs). Manejo integrado de doenças e pragas: Hortaliças. Viçosa: UFV, p. 115-136.

LOUWS, F.J.; RADEAMAKER, J.L.W.; DE BRUIJIN, F. J. 1999. The theree D's of PCR-based genomic analysis of phytobacteria: diversity, detection and disease diagnosis. Annual Review of Phytopathology 37:81-125.

LUE, Y.S.; DENG, W.L.; WU, Y.F.; CHENG, A.S.; HSU, S.T.; TZENG, K.C. 2010. Characterization of Xanthomonas associated with bacterial spot of tomato and pepper in Taiwan. Plant Pathology Bulletin 19:181-190.

MAHUKU, G.S.A simple extraction method suitable for PCR-based analysis of plant, fungal, and bacterial DNA. 2004. Plant Molecular Biology Reporter, Athens 22:71-81.

MARIANO, R. L. R. 2000. Manual de práticas em fitobacteriologia. Recife : O Autor. Cap.7, p.65-66. Reaçao de hipersensibilidade a bactérias fitopatogenicas. 
MINSAVAGE, G.V.; DAHLBECK, D.; WHALEN, V.; KEARNEY,B.; BONAS, U.; STASKAWICZ, B.J.; STALL , R. E. 1990. Gene-for-gene relationships specifying disease resistance in Xanthomonas campestris pv. vesicatoria pepper interactions. Molecular Plant Microbe Interactions 3(1):41-47.

MORETTI, C.; AMATULLI, M.T.; BUONAURIO, R. 2009. PCR- based assay for the detection of Xanthomonas euvesicatoria causing pepper and tomato bacterial spot. Letters in Microbiology 49:466-471.

NIEPOLD, F.; ANDERSON, D.; MILLS, D. 1985. Cloning determinants of pathogenesis from Pseudomonas syringae pv. syringae. Proceedings of the National Academy of Sciences of the USA 82:406.

O'GARRO, L. W.; GORE, J.P FERGUSON E. 1999. Races of Xanthomonas campestris pv. vesicatoria overcoming the gene $\mathrm{BS} 2$ for Bacterial Spot resistance in pepper, prevalent on Capsicum chinese in Barbados and Granada and weakly pathogenic on Bell pepper and tomato in the field. Plant Pathology 48:588-594.

PEREIRA, R. C. 2010. Ocorrência, caracterização e identificação das espécies de Xanthomonas causadoras de mancha-bacteriana em tomate para mesa no Brasil. Dissertação (Mestrado em Fitopatologia) Universidade de Brasília, Brasília.

PEREIRA, R.C.; ARAÚJO, E.R.; FERREIRA, M.A.S.V.; QUEZADO-DUVAL, A.M. 2011. Occurrence of Xanthomonas species causing bacterial spot in fresh market tomato fields in Brazil. In: III International Symposium on Tomato Diseases 914:61-64.

POHRONEZNY, K.; HEWIT, M.; INATE, J.; DATANOFF, F. 1992. Wind-generated sand injury as factors in infection of peppers by Xanthomonas campestris pv. vesicatoria. Plant Disease 76:1036-1039.

QUEZADO-DUVAL A.M.; LOPES, C.A. 2010. Mancha-bacteriana: uma atualização para o sistema de produção integrada de tomate indústria. Embrapa Hortaliças. Brasília-DF. Circular Técnica, 24p. 
QUEZADO-DUVAL, A.M.; LOPES, C.A.; LEITE JÚNIOR, R.P.; LIMA, M.F.; CAMARGO, L.E.A. 2005. Diversity of Xanthomonas spp. associated with bacterial spot of processing tomatoes in Brazil. Acta Horticulturae 695:101-108.

QUEZADO-DUVAL, A.M.; GAZZOTO FILHO, A.; LEITE JÚNIOR, R.P.; CAMARGO L.E.A. 2003. Sensibilidade a cobre, estreptomicina e oxitetraciclina em Xanthomonas spp. associadas à mancha-bacteriana do tomate para processamento industrial. Horticultura Brasileira 21:672-677.

RADEMAKER， J.L.W.; HOSTE， B.; LOUWS， F.J.; KERSTERS， K.; SWINGS， J.; VAUTERIN, L.; VAUTERIN, P.; DE BRUIJIN, F.J. 2000. Comparison of AFLP and rep-PCR genomic fingerprinting with DNA-DNA homology studies: Xanthomonas as a model system. International Journal of Systematic and Evolutionary Microbiology 50:665-677.

RITCHIE, D.F.; KOUSIK, C. S.; PAXTON, T. C. 1998. Response of bacterial spot pathogen strains o four major resistance genes in pepper. In: THE NATIONAL PEPPER CONFERENCE, Tampa. Proceedings. Tampa: FFVA, p.14.

ROMERO, A.M.; KOUSSIK, C.S.; RITCHIE, D.F. 2002. Temperature sensitivity oh the hypersensitive response of bell pepper to Xanthomonas axonopodis pv. vesicatoria. Phytopathology 92(2):197-203

ROMEIRO, R. S. Bactérias Fitopatogênicas. 1995. Viçosa, Imprensa Universitária - UFV, 367p.

SAHIN, F.; MILLER, S.A. 1998. Resistance in Capsicum pubescens to Xanthomonas campestris pv. vesicatoria pepper race 6. Plant disease 82(7):794-799.

SAHIN, F.; MILLER, S.A. 1996. Characterization of Ohio strains of Xantomonas campestris pv. vesicatoria , causal agent of bacterial spot of pepper. Plant Disease 80(7):773-778.

SWORDS, K.M.M.; DAHLBECK, D.; KEARNEY, B.; ROY, M.; STASKAWICZ, B.J. 1996. Spontaneous and induced mutations in single open reading frame to both virulence and 
avirulence in Xanthomonas campestris pv. vesicatoria avrBs2. Journal of Bacterioly 178:46614669.

VAUTERIN, L.; HOSTE, B.; KERSTERS, K.; SWINGS, J. 1995. Reclassification of Xanthomonas. International Union of Microbiological societies int. International Journal of Systematic Bacteriology 45:472-489.

VERSALOVIC, J.; KOEUTH, T.; LUPSKI, J.R. 1991. Distribution of repetitive DNA sequences in eubacteria and application to fingerprinting of bacterial genomes. Nucleic Acids Research, 19:6823-6831.

WANG, J. F.; JONES, J. B.; SCOTT, T. W.; STALL, R. E. 1994. Several genes in Lycopersicon esculentum control hypersensitivity to Xanthomonas campestris pv. vesicatoria. Phytopathology 84(7):702-706.

WHALEN, M.; STALL, R.E.; STASKAWICZ, B.J. 1988. Characterization of a gene from a tomato pathogen determining hypersensitive resistance in non-host species and genetic analysis of this resistance in bean. Proceedings of the National Academy of Sciences USA 85:67436747.

WHALEN, M.C.; WANG, J.F. CARLAND, F.M.; HEISKELL, M.E.; DAHLBECK, D.; MINSAVAGE, G.V.; JONES, J.B.; SCOTT, J.W.; STALL, R.E.; STASKAWICZ, B.J. 1993. Avirulence gene avrRxv from Xanthomonas campestris pv.vesicatoria specifies resistance on tomato line Hawaii 7998. Molecular Plant-Microbe Interactions 6(5):616-627.

WIERZBICKI, R. Identificação de raças de Xanthomonas spp. patogênicas a pimentão no estado de São Paulo. 2004. (Dissertação em Agronomia, Área de Concentração: Fitopatologia). Escola Superior Luiz de Queiróz, Universidade de São Paulo 72p.

YU, Z.H.; WANG, F.J.; STALL, R.E.; VALLEJOS, C.E. 1995. Genomic localization of tomato genes that control a hypersensitive reaction to Xanthomonas campestris pv. vesicatoria (Doidge) Dye. Genetics 141:675-682. 


\section{CAPÍTULO 2}

Sensibilidade ao cobre de isolados de Xanthomonas spp. associadas à mancha-bacteriana em Capsicum 


\section{SENSIBILIDADE AO COBRE DE ISOLADOS DE XANTHOMONAS SPP. ASSOCIADOS À MANCHA- BACTERIANA EM CAPSICUM}

\section{RESUMO}

A mancha-bacteriana ocorre praticamente em todas as regiões produtoras de pimentas e pimentões no Brasil, representando fator limitante da produção em condições favoráveis à doença. Avaliou-se a sensibilidade in vitro de 73 isolados de espécies de Xanthomonas spp. associadas à mancha-bacteriana de Capsicum no Brasil ao cobre. Os isolados foram obtidos de amostras de folhas sintomáticas procedentes de campos comerciais de pimentas e pimentões no Distrito Federal e nos estados de Goiás, Ceará, Bahia, Sergipe, Pernambuco, Roraima, Pará, Amazonas, Minas Gerais, Espírito Santo e São Paulo entre os anos 1982 a 2014. Gotas de $5 \mu 1$ de suspensão bacteriana foram depositadas em meio CYE suplementado com sulfato de cobre nas concentrações de 50, 100 e $200 \mu \mathrm{g} / \mathrm{mL}$. Todos os isolados deste estudo apresentaram crescimento confluente no controle (ausência de cobre). Nas concentrações de 50 e $100 \mu \mathrm{g} / \mathrm{mL}, 74 \%$ e $63 \%$ dos isolados foram insensíveis, respectivamente. Apenas $10 \%$ dos isolados foram insensíveis à maior concentração do produto $(200 \mu \mathrm{g} / \mathrm{mL})$. Dos quatro isolados de Xanthomonas gardneri (43-P, 106-P, 119-P e 120-P), apenas o 106-P foi sensível à menor concentração do sulfato de cobre $(50 \mu \mathrm{g} / \mathrm{mL})$. O isolado de $X$. perforans foi sensível somente na concentração de $200 \mu \mathrm{g} / \mathrm{mL}$. Já para os 68 isolados identificados como $X$. euvesicatoria, $42,9 \%$ foram sensíveis a $50 \mu \mathrm{g} / \mathrm{mL}$. Observouse um aumento na frequência de isolados insensíveis à concentração crescente de cobre ao longo dos anos. Para o cultivo de Capsicum no Brasil, o portfólio de produtos registrados para o controle está basicamente restrito a esse princípio ativo, que é utilizado de maneira intensiva, portanto espera-se uma manutenção ou até aumento da pressão de seleção exercida sobre as populações de Xanthomonas sp. em direção à insensibilidade ao produto. Assim, novas alternativas de controle via aplicação de produtos registrados, aliado ao emprego de resistência varietal, devem ser buscadas.

Palavras-chave: Xanthomonas euvesicatoria, X. gardneri, pimentas, pimentões, controle químico.

Orientadora- Alice Maria Quezado Duval- Embrapa Hortaliças. 


\title{
SENSIBILITY TO COPPER OF ISOLATED XANTHOMONAS SPP. ASSOCIATED TO BACTERIAL SPOT IN CAPSICUM
}

\begin{abstract}
Bacterial spot occurs in almost all regions where peppers and bell peppers are produced in Brazil. The disease is a limiting yield factor where favorable conditions for disease development are predominant, such as hight temperatures and relative humidity. In vitro sensitivity to copper of 73 isolates of Xanthomonas spp. associated with bacterial spot on Capsicum in Brazil was evaluated. The isolates were obtained from symptomatic leaves of samples from commercial fields of peppers and bell peppers located in the Federal District and the states of Goiás, Ceará, Bahia, Sergipe, Pernambuco, Roraima, Pará, Amazonas, Minas Gerais, Espírito Santo, and São Paulo between the years 1982 and 2014. Aliquots of 5uL of bacterial suspension were deposited in a CYE medium ammended with copper sulphate at concentrations of 50, 100 and $200 \mu \mathrm{g} / \mathrm{mL}$. All isolates of this study presented confluent growth in the check plates (no copper ammeded). At concentrations of 50 and $100 \mu \mathrm{g} / \mathrm{mL}$, $74 \%$ and $63 \%$ of the isolates were insensitive, respectively. Only $10 \%$ of the isolates were insensitive to higher the concentration $(200 \mu \mathrm{g} / \mathrm{mL})$. Out of the four isolate of Xanthomonas gardneri (43-P, 106-P, 119-P and 120-P), only the isolate P-106 was sensitive to the lower concentrations of copper sulfate $(50 \mu \mathrm{g} / \mathrm{mL})$. The isolated $X$. perforans was only sensitive to the concentration of $200 \mu \mathrm{g} / \mathrm{mL}$ As for the 68 isolates of X. euvesicatoria, $42.9 \%$ were sensitive to $50 \mu \mathrm{g} / \mathrm{mL}$. The number of insensitive isolates increased over the years. An increase in the frequency of insensitive isolates to the increasing concentration of copper over the years was observed. Since in the case of Capsicum crops in Brazil, the portfolio of products registered for control is basically restricted to this active ingredient, which is used intensively, it is expected a maintenance or even an increase in the selection pressure over the populations of Xanthomonas sp. towards the insensitivity to cupper. Thus, new alternatives of chemical control should be surched, together with the use of resistant varieties.
\end{abstract}

Keywords: Xanthomonas euvesicatoria, X. gardneri, peppers, bell peppers, chemical control.

Advisor- Alice Maria Quezado Duval- Embrapa Hortaliças. 


\section{INTRODUÇÃO}

O cultivo de pimentas e pimentões é uma atividade para o setor agrícola brasileiro. No entanto, sua produtividade é afetada pó fatores bióticos e abióticos (Maringoni \& Kimati, 1987) e dentre eles, doenças de várias etiologias. A mancha-bacteriana é considerada uma das principais doenças destrutivas da cultura causando desfolha intensa quando em condições favoráveis, deixando os frutos expostos ao sol, depreciando-os e diminuindo a produção. $\mathrm{O}$ agente causal está atualmente associado a quatro espécies de Xanthomonas (Jones et al., 2004): X. euvesicatoria, X. gardneri e mais recentemente $X$. perforanas (Bart et al., 2012) e X. vesicatoria (Kizheva et al., 2013).

Sementes, restos culturais, plantas voluntárias e plantas daninhas atuam como fontes de inóculo (Jones et al., 1984), o que torna difícil impedir a ocorrência e a disseminação da doença na lavoura. Os trabalhos voltados ao manejo da mancha-bacteriana vêm sendo baseados no desenvolvimento de variedades resistentes (Jones et al., 2002; Stall et al., 2009) e na avaliação da eficiência de agrotóxicos (Aguiar et al., 2000, Aguiar et al., 2003; Bounario et al., 2002; Costa et al., 2002).

Atualmente no mercado Brasileiro existem somente as variedades de pimentão Dahra Rx (Sakata, 2014), Commandant (Syngenta, 2014), Paloma (Horticeres, 2015) e Impacto (Seminis) que conferem resistência a determinadas raças de Xanthomonas euvesicatoria. Com isso, para o manejo da doença, o emprego de agrotóxicos de forma preventiva, por meio da aplicação de fungicidas cúpricos e antibióticos agrícolas, tem sido históricamente utilizado. No entanto, o aparecimento de estirpes resistentes a esses produtos tem contribuído para a baixa eficiência do controle. A baixa eficácia do controle químico da mancha-bacteriana em campos de cultivo pode ser explicada pela seleção de isolados resistentes aos produtos químicos utilizados. O primeiro relato de resistência de Xanthomonas sp. de pimentão a produtos cúpricos ocorreu na Flórida, em 1983 (Marco \& Stall, 1983). No México, isolados 
de Xanthomonas sp. resistentes a cobre foram identificados em lavouras comerciais de pimentão. Nessas áreas, compostos cúpricos foram utilizados para o controle da manchabacteriana por mais de 30 anos (Adaskaveg \& Hine, 1985). Em 1999, Bouzar et al. relataram o aparecimento de estirpes resistentes à estreptomicina e ao cobre, no Caribe e na América Central. A partir desses relatos iniciais, levantamentos têm sido realizados em diversos países, para aferir a eficiência do controle químico por meio da sensibilidade das Xanthomonas associadas ao tomateiro (Solanum lycopersicum) e a Capsicum.

A ocorrência de isolados de Xanthomonas spp. Insensíveis ao cobre em campos de tomate e pimentão também tem sido relatada por vários autores (Marco \& Stall, 1983; Adaskaveg et al., 1985; Minsavage et al., 1990; Ritchie \& Dittapongpitch, 1991; Buonaurio et al., 1994; O’ Garro, 1998; Bouzar et al., 1999; Aguiar et al., 2000; Quezado-Duval, 2003; Pereira, 2010; Costa, 2012).

Aguiar et al. (2003) avaliaram o efeito da pulverização de sulfato de cobre, oxicloreto de cobre, óxido cuproso e óxido cuproso em mistura com mancozeb no controle da manchabacteriana do pimentão. As pulverizações com óxido cuproso e a sua mistura com mancozeb reduziram significativamente a população epifítica de Xanthomonas spp. e a doença teve bons níveis de controle com esses produtos.

Estudo desenvolvido por Martin et al. (2004), em plantios de pimentão na Austrália, revelou a ocorrência de isolados de Xanthomonas spp. insesíveis ao sulfato de cobre. No campo, a proporção de isolados resistentes aumentou após 12 pulverizações de cobre e estes se tornaram prevalentes após 21 pulverizações, devido à pressão de seleção exercida pelas constantes aplicações do produto químico.

No Brasil, encontram-se relatos da baixa eficiência de produtos cúpricos em lavouras de tomate para processamento industrial (Quezado-Soares \& Lopes, 1999) e de pimentão (Carmo et al., 2001). Maringoni e Kimati (1987c) relataram a baixa sensibilidade de isolados 
de Xanthomonas spp., obtidos de tomateiro e pimentão ao sulfato de cobre, oxicloreto de cobre e hidróxido de cobre, na concentração de $100 \mu \mathrm{g} / \mathrm{ml}$. Entretanto, os isolados se mostraram sensíveis às misturas de fungicidas cúpricos (hidróxido de cobre, oxicloreto de cobre e óxido cuproso) com ditiocarbamatos (maneb, mancozeb e zineb), evidenciando um efeito sinérgico entre os produtos. Essa situação é definida, segundo Castro (2009), como uma interação entre os agentes tóxicos que produz um efeito maior que o esperado em relação às ações individuais.

Nos Estados do Rio de Janeiro e de São Paulo, Aguiar et al. (2000) encontraram isolados de Xanthomonas spp. de pimentão e tomateiro resistentes a até $1800 \mu \mathrm{g} / \mathrm{mL}$ de sulfato de cobre. Carmo et al. (2001), avaliando o efeito de pulverizações semanais de oxicloreto de cobre no progresso da mancha-bacteriana em pimentão, observaram que a eficiência deste produto químico é variável, e na maioria das vezes, ineficiente, principalmente, quando as condições ambientais são propícias ao desenvolvimento da doença.

Em Goiás, os isolados associados à mancha-bacteriana do tomate para processamento industrial, de diferentes espécies de Xanthomonas foram analisados para a sensibilidade ao cobre e à estreptomicina, com $98 \%$ dos isolados de X. gardneri e cerca de $56 \%$ de $X$. perforans apresentando-se insensíveis a $25 \mathrm{ug} / \mathrm{mL}$ de estreptomicina. Nenhum isolado foi

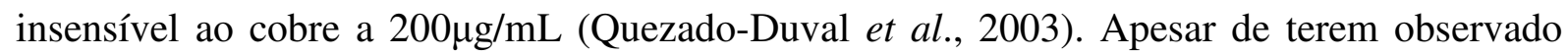
que havia sensibilidade diferencial entre isolados coletados nessas lavouras os níveis de concentração $(50 \mu \mathrm{g} / \mathrm{mL})$ em que foram encontrados isolados insensíveis foram considerados baixos, inferiores aos relatados nos E.U.A $(200 \mu \mathrm{g} / \mathrm{mL})$.

Quezado-Duval et al. (2003) relataram um aumento na proporção de isolados resistentes ao cobre ao longo do tempo $(50 \mu \mathrm{g} / \mathrm{mL})$ quando em lavouras de tomate para processamento industrial com uso mais intensivo de cobre como agente de controle da mancha-bacteriana. Da mesma forma Pontes et al (2012) avaliaram a sensibilidade ao cobre 
de isolados de Xanthomonas perforans, oriundos de parcelas de tomate rasteiro que diferiam quanto ao número de aplicações de hidróxido de cobre durante o cultivo. $\mathrm{O}$ isolado oriundo das parcelas com maior número de aplicações de hidróxido de cobre cresceu em meio de cultura com $200 \mu \mathrm{g} / \mathrm{mL}$ de $\mathrm{Cu}+$, enquanto o isolado de parcelas não tratadas apenas cresceu em meio com $100 \mu \mathrm{g} / \mathrm{mL}$ de $\mathrm{Cu}+$. Com base nesses resultados, observa-se que o uso contínuo de produtos a base de cobre pode levar a seleção de populações de Xanthomonas insensíveis a cobre.

Atualmente, no Brasil, para o controle químico da mancha bacteriana do pimentão, há registro no Ministério da Agricultura Pecuária e Abastecimento apenas dos princípios ativos hidróxido de cobre e sulfato de cobre (AGROFIT, 2014).

Para o controle das fitobacterioses deve-se recorrer, sempre que possível, a cultivares resistentes, redução do inóculo inicial, práticas de manejo que tornem o ambiente menos favorável à doença, e o uso de agrotóxicos registrados para a cultura. No entanto, esses agroquímicos, sob manejo incorreto, podem encarecer os custos de produção, intensificar a pressão de seleção sobre populações bacterianas e tornando-os ineficazes (Marco \& Stall, 1983; Adaskaveg \& Hine, 1985; Maringoni \& Kimati, 1987).

Tendo em vista as constantes perdas causadas pela mancha-bacteriana em Capsicum, a variação na eficiência de seu controle com formulações à base de cobre, o presente trabalho, teve como objetivo avaliar in vitro a sensibilidade ao cobre de 73 isolados coletados em campos comerciais de pimentas e pimentões no Brasil. 


\section{MATERIAL E MÉTODOS}

\section{Testes de sensibilidade in vitro ao sulfato de cobre}

Foram utilizados 73 isolados da coleção de trabalho do Laboratório de Fitopatologia da Embrapa Hortaliças, Brasília, DF, para os testes de sensibilidade ao cobre (Tabela 1). Os isolados foram, obtidos de amostras de folhas de Capsicum (ou de pimentas de pimentões) com sintomas de mancha-bacteriana coletadas em lavouras de pimentas ou de pimentão no Brasil.

Os isolados foram recuperados do tampão fosfato pela deposição de uma gota em alça de platínha em meio NA (nutriente ágar), ), contendo 3,0 g/L de extrato de carne; 5,0 g/L de peptona; 2,5 g/L de sacarose e $17 \mathrm{~g} / \mathrm{L}$ de ágar, seguida de riscagem e incubados em BOD por 4 dias a $28^{\circ} \mathrm{C}$. Após o crescimento bacteriano, repicou-se uma colônia em meio de cultura (NA) de uma nova placa, incubando-a por 48 horas a $28^{\circ} \mathrm{C}$, para posterior preparo da suspensão. Ajustou-se a concentração da suspensão bacteriana em espectrofotômetro para aproximadamente $5 \times 10^{8} \mathrm{UFC} / \mathrm{mL}$. Em seguida, depositou-se alíquotas de $10 \mu \mathrm{lem}$ triplicatas, em placas contendo meio CYE (casitone-yeast extract, Zevenhuizen et al., 1979), contendo 1,7 g/L de casitona; 0,35 g/L de extrato de levedura; 2,0 g/L de glicerol e $15 \mathrm{~g} / \mathrm{L}$ de ágar, suplementado com sulfato de cobre $\left(\mathrm{CuSO}_{4} .5 \mathrm{H}_{2} \mathrm{O}\right.$, Merck) nas concentrações de 50,100 e $200 \mathrm{ppm}(\mu \mathrm{g} / \mathrm{mL})$. Essas concentrações correspondem a 0,2; 0,4 e 0,8 $\mathrm{mM}$ de $\mathrm{CuSO}_{4}$, respectivamente. Alíquotas de todos os isolados avaliados foram depositadas em meio CYE sem suplementação de cobre como controle comparativo para determinação do crescimento confluente. As placas foram incubadas por 72 horas a $28^{\circ} \mathrm{C}$, para posterior avaliação de reação de sensibilidade dos isolados. Foram atribuídas classes para as diferentes reações dos isolados ao cobre. Isolados sensíveis (S) foram aqueles que não cresceram na concentração de $50 \mu \mathrm{g} / \mathrm{mL}$ de sulfato de cobre; moderadamente sensíveis (MS) foram aqueles que cresceram a 
$50 \mu \mathrm{g} / \mathrm{mL}$, mas não a $100 \mu \mathrm{g} / \mathrm{mL}$; moderadamente insensíveis (MI) cresceram a $100 \mu \mathrm{g} / \mathrm{mL}$, mas não a $200 \mu \mathrm{g} / \mathrm{mL}$; e isolados insensíveis (I) cresceram a $200 \mu \mathrm{g} / \mathrm{mL}$ de sulfato de cobre, de acordo com metodologia utilizada por Costa et al., 2012.

Tabela 1. Lista de isolados da coleção (1982 a 2014) de Xanthomonas associadas a Capsicum do Laboratório de Fitopatologia da Embrapa Hortaliças, Brasília, DF.

\begin{tabular}{|c|c|c|c|c|c|}
\hline Código & Hospedeira & Cultivar & Ano & Local & Espécie \\
\hline $3-\mathrm{P}$ & Pimenta & - & 1982 & Brasília - DF & X. euvesicatoria \\
\hline $5-\mathrm{P}$ & Pimenta & - & 1983 & Brasília - DF & X. euvesicatoria \\
\hline 6-P & Pimenta & - & 1984 & Itabaiana - SE & X. euvesicatoria \\
\hline 8-P & Pimenta & - & 1984 & Camocim São Félix - PE & X. euvesicatoria \\
\hline 9-P & Pimentão & - & 1984 & Vitória de Santo Antão - PE & X. euvesicatoria \\
\hline $11-\mathrm{P}$ & Pimentão & - & 1984 & Brasília - DF & X. euvesicatoria \\
\hline $15-\mathrm{P}$ & Pimentão & - & 1982 & Monte Mor - SP & X. euvesicatoria \\
\hline 16-P & Pimenta & - & 1991 & Manaus AM & X. euvesicatoria \\
\hline $17-\mathrm{P}$ & Pimenta & - & 1991 & Manaus - AM & X. euvesicatoria \\
\hline 20-P & Pimentão & - & 1995 & Botucatu - SP & X. euvesicatoria \\
\hline 24-P & Pimentão & Mallorca & 1997 & Brazilândia - MG & X. euvesicatoria \\
\hline $25-\mathrm{P}$ & Pimentão & Mallorca & 1997 & Brazilândia - MG & X. euvesicatoria \\
\hline 29-P & Pimentão & Mallorca & 1997 & Presidente Olegário - MG & X. euvesicatoria \\
\hline 30-P & Pimentão & Mallorca & 1997 & Presidente Olegário - MG & X. euvesicatoria \\
\hline 33-P & Pimentão & Mallorca & 1997 & Presidente Olegário - MG & X. euvesicatoria \\
\hline 35-P & Pimentão & Mallorca & 1997 & Presidente Olegário - MG & X. euvesicatoria \\
\hline 36-P & Pimentão & - & 1998 & Juazeiro - BA & X. euvesicatoria \\
\hline 37-P & Pimentão & - & 1998 & Juazeiro - BA & X. euvesicatoria \\
\hline 38-P & Pimenta & Cheiro* & 1999 & Tefé - AM & X. euvesicatoria \\
\hline 39-P & Pimenta & Cheiro* & 1999 & Parintins - AM & X. euvesicatoria \\
\hline 40-P & Pimentão & Cascadura & 1999 & Alto Alegre Boa Vista - RR & X. euvesicatoria \\
\hline 41-P & Pimentão & - & 1991 & Lins - SP & X. euvesicatoria \\
\hline 42-P & Pimenta & - & 2001 & Brasília -DF & X. euvesicatoria \\
\hline 43-P & Pimentão & Mallorca & 2002 & Brasilândia - MG & X. gardneri \\
\hline 49-P & Pimentão & - & 2002 & Formosa - GO & X. euvesicatoria \\
\hline 50-P & Pimentão & - & 2002 & Brasília - DF ${ }^{1}$ & X. euvesicatoria \\
\hline 51-P & Pimentão & Margarita & 2002 & Brasília - DF ${ }^{1}$ & X. euvesicatoria \\
\hline 55-P & Pimentão & - & 2003 & Belém - PA & X. euvesicatoria \\
\hline 58-P & Pimentão & - & 2003 & Petrolina - GO & X. euvesicatoria \\
\hline 59-P & Pimentão & - & 2003 & Petrolina - GO & X. euvesicatoria \\
\hline 62-P & Pimenta & Cheiro* & 2003 & Morrinhos - GO & X. euvesicatoria \\
\hline 63-P & Pimenta & Cumari & 2003 & Morrinhos - GO & X. euvesicatoria \\
\hline 72-P & Pimenta & Cheiro* & 2009 & Gama - DF & X. euvesicatoria \\
\hline 75-P & Pimentão & Cayenne & 2009 & Ceilândia - DF & X. euvesicatoria \\
\hline 77-P & Pimentão & Magali-R & 2009 & Araguari - MG & X. euvesicatoria \\
\hline 79-P & Pimentão & Magali-R & 2009 & Guaraciaba - CE & X. euvesicatoria \\
\hline 81-P & Pimentão & Safari & 2009 & Ubajara - CE & X. euvesicatoria \\
\hline
\end{tabular}




\begin{tabular}{|c|c|c|c|c|c|}
\hline 83-P & Pimentão & Marta-R & 2009 & São Benedito - CE & X. euvesicatoria \\
\hline 84-P & Pimentão & Marta-R & 2009 & São Benedito - CE & X. euvesicatoria \\
\hline $85-\mathrm{P}$ & Pimentão & Natali & 2009 & Ubajara - CE & X. euvesicatoria \\
\hline $86-\mathrm{P}$ & Pimenta & Cheiro* & 2009 & Tianguá - CE & X. euvesicatoria \\
\hline 87-P & Pimenta & Cheiro* & 2009 & Tianguá - CE & X. euvesicatoria \\
\hline 89-P & Pimentão & Dahra & 2009 & Tianguá - CE & X. euvesicatoria \\
\hline $90-\mathrm{P}$ & Pimentão & Dahra & 2009 & Tianguá - CE & X. euvesicatoria \\
\hline 92-P & Pimentão & Magali-R & 2009 & Venda Nova do Imigrante - ES & X. euvesicatoria \\
\hline 93-P & Pimentão & Magali-R & 2009 & Venda Nova do Imigrante - ES & X. euvesicatoria \\
\hline 94-P & Pimentão & - & 2009 & São Benedito - CE & X. euvesicatoria \\
\hline $95-\mathrm{P}$ & Pimentão & - & 2009 & São Benedito - CE & X. euvesicatoria \\
\hline 96-P & Pimentão & - & 2010 & Brazabantes - GO & X. euvesicatoria \\
\hline 98-P & Pimentão & Natali & 2011 & Jaguaquara - BA & X. euvesicatoria \\
\hline 99-P & Pimentão & Natali & 2011 & Jaguaquara - BA & X. euvesicatoria \\
\hline $100-\mathrm{P}$ & Pimentão & Dahra RX & 2011 & Brasília - DF & X. euvesicatoria \\
\hline $101-\mathrm{P}$ & Pimentão & Dahra RX & 2011 & Brasília - $\mathrm{DF}^{3}$ & X. euvesicatoria \\
\hline 102-P & Pimenta & - & 2011 & Brasília - DF ${ }^{3}$ & X. euvesicatoria \\
\hline 103-P & Pimenta & - & 2011 & Brasília - DF ${ }^{3}$ & X. euvesicatoria \\
\hline $104-\mathrm{P}$ & Pimentão & Paloma & 2011 & Brasília - DF ${ }^{3}$ & X. euvesicatoria \\
\hline $105-\mathrm{P}$ & Pimenta & Cheiro* & 2011 & Brasília - DF ${ }^{2}$ & X. euvesicatoria \\
\hline 106-P & Pimentão & Margarita & 2011 & Alto Caxixe - ES & X. gardneri \\
\hline 109-P & Pimentão & Margarita & 2011 & Alto Caxixe - ES & X. euvesicatoria \\
\hline $110-\mathrm{P}$ & Pimentão & Dahra RX & 2011 & Brasília - DF & X. euvesicatoria \\
\hline $111-\mathrm{P}$ & Pimentão & Dahra RX & 2011 & Brasília - DF ${ }^{3}$ & X. euvesicatoria \\
\hline $112-\mathrm{P}$ & Pimentão & Dahra RX & 2011 & Brasília - DF ${ }^{3}$ & X. euvesicatoria \\
\hline $113-\mathrm{P}$ & Pimentão & Dahra RX & 2011 & Brasília - DF ${ }^{3}$ & X. euvesicatoria \\
\hline 114-P & Pimentão & Dahra RX & 2011 & Brasília - DF ${ }^{3}$ & X. euvesicatoria \\
\hline $115-\mathrm{P}$ & Pimentão & Dahra RX & 2011 & Brasília - DF ${ }^{3}$ & X. euvesicatoria \\
\hline $116-\mathrm{P}$ & Pimentão & Dahra RX & 2011 & Brasília - DF ${ }^{3}$ & X. euvesicatoria \\
\hline $117-\mathrm{P}$ & Pimentão & Paloma & 2011 & Brasília - DF ${ }^{3}$ & X. euvesicatoria \\
\hline 118-P & Pimentão & Paloma & 2011 & Brasília - DF ${ }^{3}$ & X. euvesicatoria \\
\hline 119-P & Pimentão & - & 2011 & Capão Bonito - SP & $X$. gardneri \\
\hline 120-P & Pimentão & - & 2011 & Capão Bonito - SP & X. gardneri \\
\hline 122-P & Pimenta & - & 2012 & Gama - DF & X. euvesicatoria \\
\hline $123-\mathrm{P}$ & Pimentão & - & 2013 & Ubajara - CE & X. euvesicatoria \\
\hline 124-P & Pimentão & Safari R & 2014 & Ubajara - CE & X. perforans \\
\hline
\end{tabular}

- : Não determinado.

${ }^{1}$ NR Taquara; ${ }^{2}$ NR São José; ${ }^{3}$ NR Rio Preto.

*Refere-se ao grupo de pimenta, não à variedade. 


\section{RESULTADOS}

\section{Testes de sensibilidade in vitro ao sulfato de cobre}

No controle (ausência de cobre) 100\% dos 73 isolados apresentaram crescimento confluente em todas as repetições, tendo sido observado diferença em sensibilidade entre os isolados em outras concentrações (Figura 1). Na concentração de $50 \mu \mathrm{g} / \mathrm{mL}, 74 \%$ dos isolados (53) foram insensíveis, na concentração de $100 \mu \mathrm{g} / \mathrm{mL}, 63 \%$ dos isolados (45) foram insensíveis. Apenas $10 \%$ dos isolados (7) foram insensíveis a maior concentração do produto $(200 \mu \mathrm{g} / \mathrm{mL})$ (Tabela 2 e Figura 2).

Dos quatro isolados identificados como Xanthomonas gardneri (43-P, 106-P, 119-P e 120-P), apenas o 106-P foi sensível a menor concentração do sulfato de cobre (50 $\mu \mathrm{g} / \mathrm{mL})$. Já para os 69 isolados identificados como X. euvesicatoria, $42,9 \%$ foram sensíveis a $50 \mu \mathrm{g} / \mathrm{mL}$.

Tabela 2. Sensibilidade ao cobre de isolados de Xanthomonas spp. causadores da manchabacteriana em Capsicum.

\begin{tabular}{ccccc}
\hline \multirow{2}{*}{ Isolados } & \multicolumn{5}{c}{ Concentrações de cobre } \\
\cline { 2 - 5 } & $\mathbf{C Y E}$ & $\mathbf{C Y E}+\mathbf{5 0} \mathbf{~ p p m}$ & $\mathbf{C Y E}+\mathbf{1 0 0} \mathbf{~ p p m}$ & $\mathbf{C Y E}+\mathbf{2 0 0} \mathbf{~ p p m}$ \\
\hline $3-\mathrm{P}$ & + & - & - & - \\
$5-\mathrm{P}$ & + & - & - & - \\
$6-\mathrm{P}$ & + & - & - & - \\
$8-\mathrm{P}$ & + & + & - & - \\
$9-\mathrm{P}$ & + & + & - & - \\
$11-\mathrm{P}$ & + & - & + & - \\
$15-\mathrm{P}$ & + & + & - & - \\
$16-\mathrm{P}$ & + & + & - & - \\
$17-\mathrm{P}$ & + & - & + & - \\
$20-\mathrm{P}$ & + & + & - & - \\
$24-\mathrm{P}$ & + & - & - & - \\
$25-\mathrm{P}$ & + & - & - & - \\
$29-\mathrm{P}$ & + & - & - & - \\
$30-\mathrm{P}$ & + & - & - & - \\
$33-\mathrm{P}$ & + & - & - & - \\
$35-\mathrm{P}$ & + & - & - & - \\
$36-\mathrm{P}$ & + & - & - & - \\
$37-\mathrm{P}$ & + & - & - & \\
$38-\mathrm{P}$ & + & - &
\end{tabular}




\begin{tabular}{|c|c|}
\hline 39-P & + \\
\hline $40-\mathrm{P}$ & + \\
\hline $41-\mathrm{P}$ & + \\
\hline $42-\mathrm{P}$ & + \\
\hline $43-\mathrm{P}$ & + \\
\hline 49-P & + \\
\hline $50-\mathrm{P}$ & + \\
\hline 51-P & + \\
\hline $55-\mathrm{P}$ & + \\
\hline 58-P & + \\
\hline 59-P & + \\
\hline 62-P & + \\
\hline 63-P & + \\
\hline 72-P & + \\
\hline $75-\mathrm{P}$ & + \\
\hline 77-P & + \\
\hline 79-P & + \\
\hline 81-P & + \\
\hline 83-P & + \\
\hline 84-P & + \\
\hline $85-\mathrm{P}$ & + \\
\hline 86-P & + \\
\hline 87-P & + \\
\hline 89-P & + \\
\hline 90-P & + \\
\hline 92-P & + \\
\hline 93-P & + \\
\hline 94-P & + \\
\hline 95-P & + \\
\hline 96-P & + \\
\hline 98-P & + \\
\hline 99-P & + \\
\hline $100-\mathrm{P}$ & + \\
\hline $101-\mathrm{P}$ & + \\
\hline $102-\mathrm{P}$ & + \\
\hline 103-P & + \\
\hline 104-P & + \\
\hline $105-\mathrm{P}$ & + \\
\hline $106-\mathrm{P}$ & + \\
\hline 109-P & + \\
\hline 110-P & + \\
\hline $111-\mathrm{P}$ & + \\
\hline $112-\mathrm{P}$ & + \\
\hline 113-P & + \\
\hline 114-P & + \\
\hline $115-\mathrm{P}$ & + \\
\hline $116-\mathrm{P}$ & + \\
\hline 117-P & + \\
\hline 118-P & + \\
\hline
\end{tabular}


119-P $\quad+\quad+$

120-P ++

122-P ++

123-P

124-P

$+$

$+$

+
+
+
+
+

+ : Isolados insensíveis nas respectivas concentrações de sulfato de cobre.

- : Isolados sensíveis nas respectivas concentrações de sulfato de cobre.
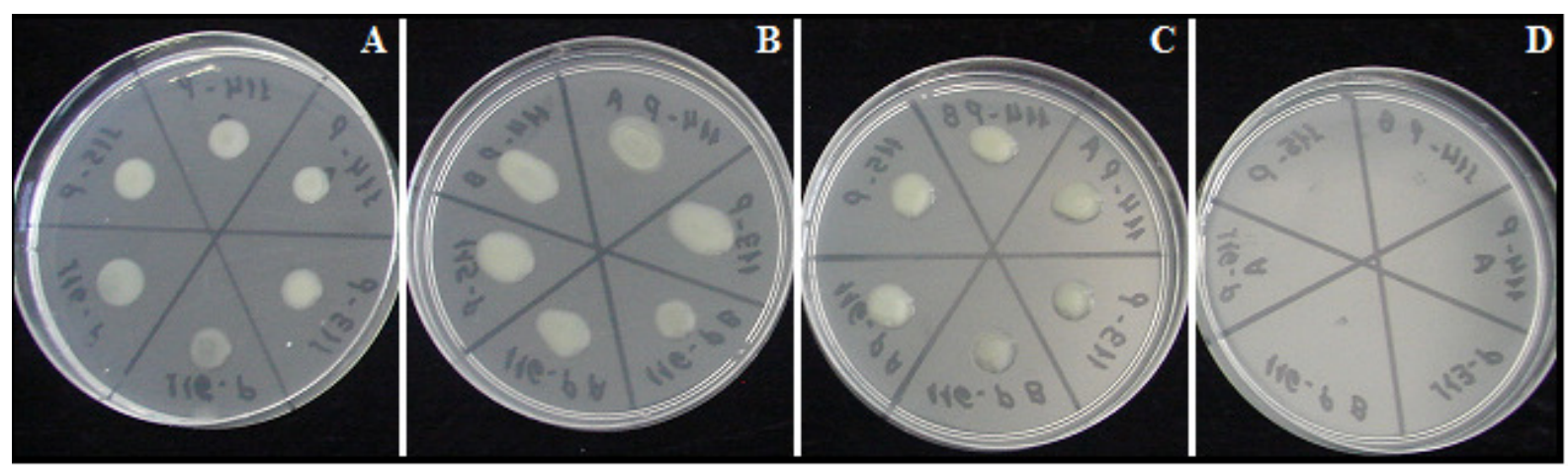

Figura 1. Reação ao cobre de isolados de Xanthomonas causadores da mancha-bacteriana em Capsicum. Sensibilidade foi determinada pelo crescimento confluente em meio CYE. A: CYE sem de sulfato de cobre. B: $50 \mu \mathrm{g} / \mathrm{mL}$ de sulfato de cobre. C: $100 \mu \mathrm{g} / \mathrm{mL}$ de sulfato de cobre. D: $200 \mu \mathrm{g} / \mathrm{mL}$ de sulfato de cobre.

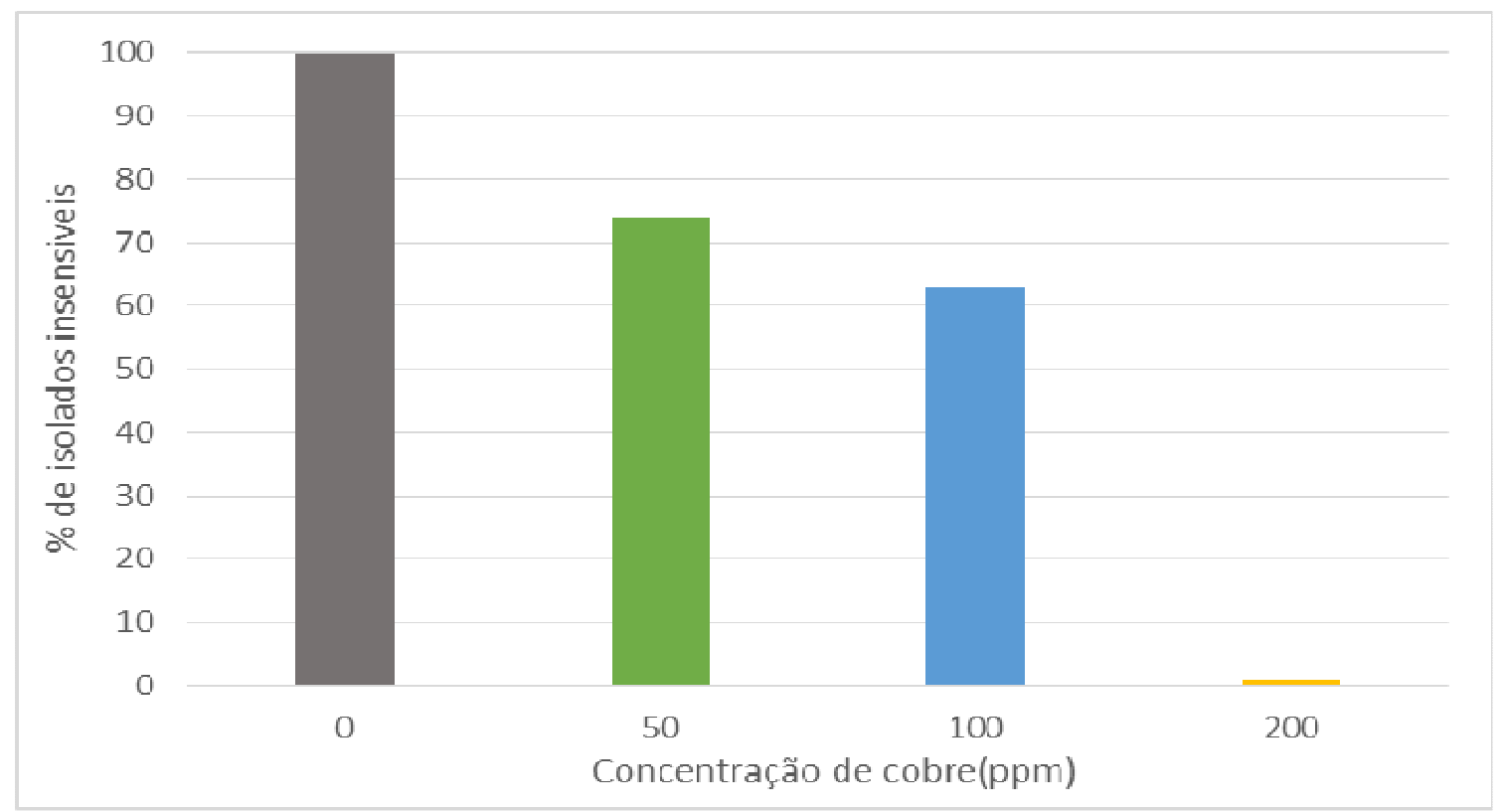

Figura 2. Insensibilidade ao cobre de isolados de Xanthomonas associadas à manchabacteriana em Capsicum. Sensibilidade foi determinada pelo crescimento confluente em meio CYE suplementado com 50; 100 e $200 \mu \mathrm{g} / \mathrm{mL}$ de sulfato de cobre. 


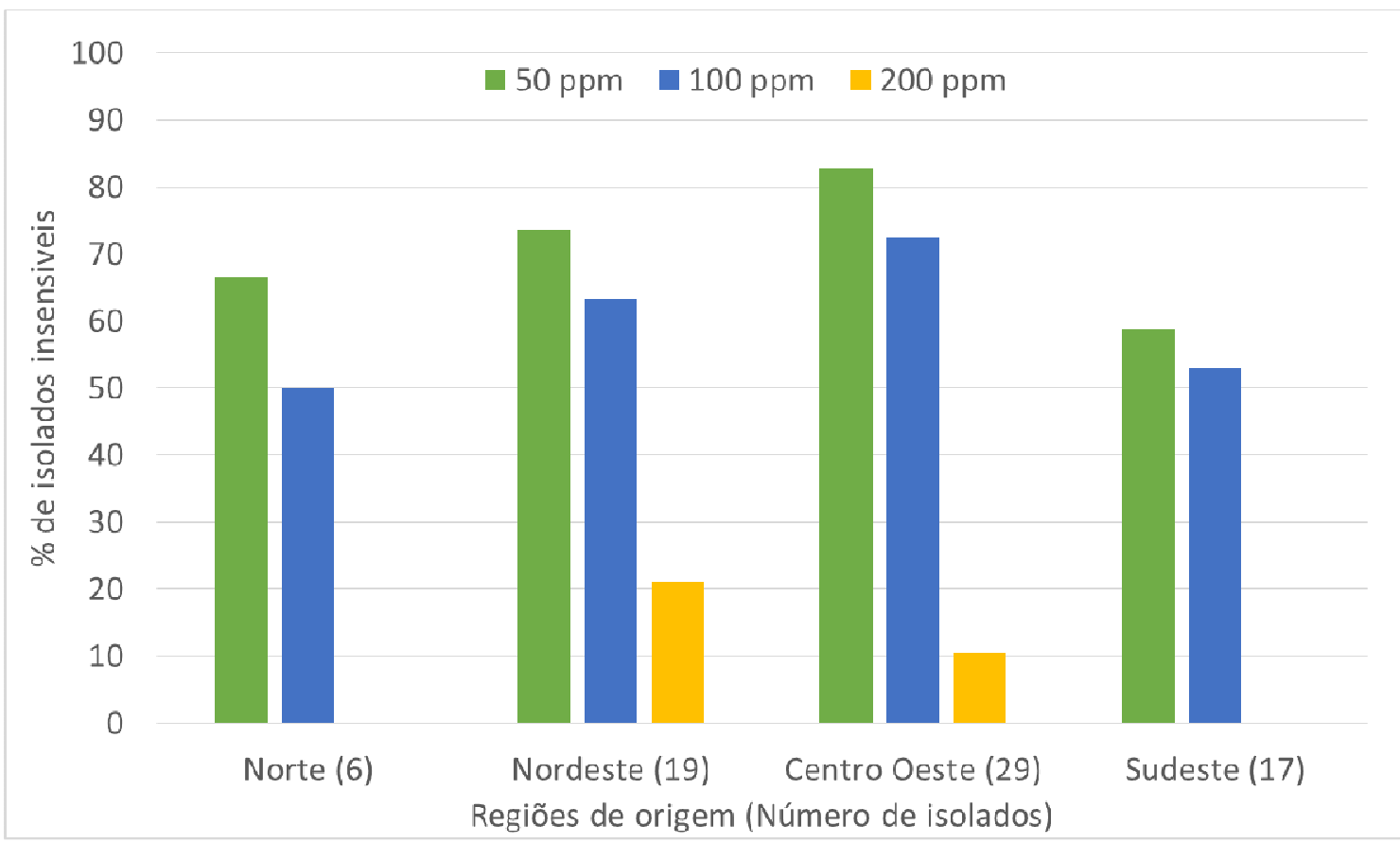

Figura 3. Porcentagem de isolados insensíveis às diferentes concentrações de cobre de acordo com a região em que foram coletados.

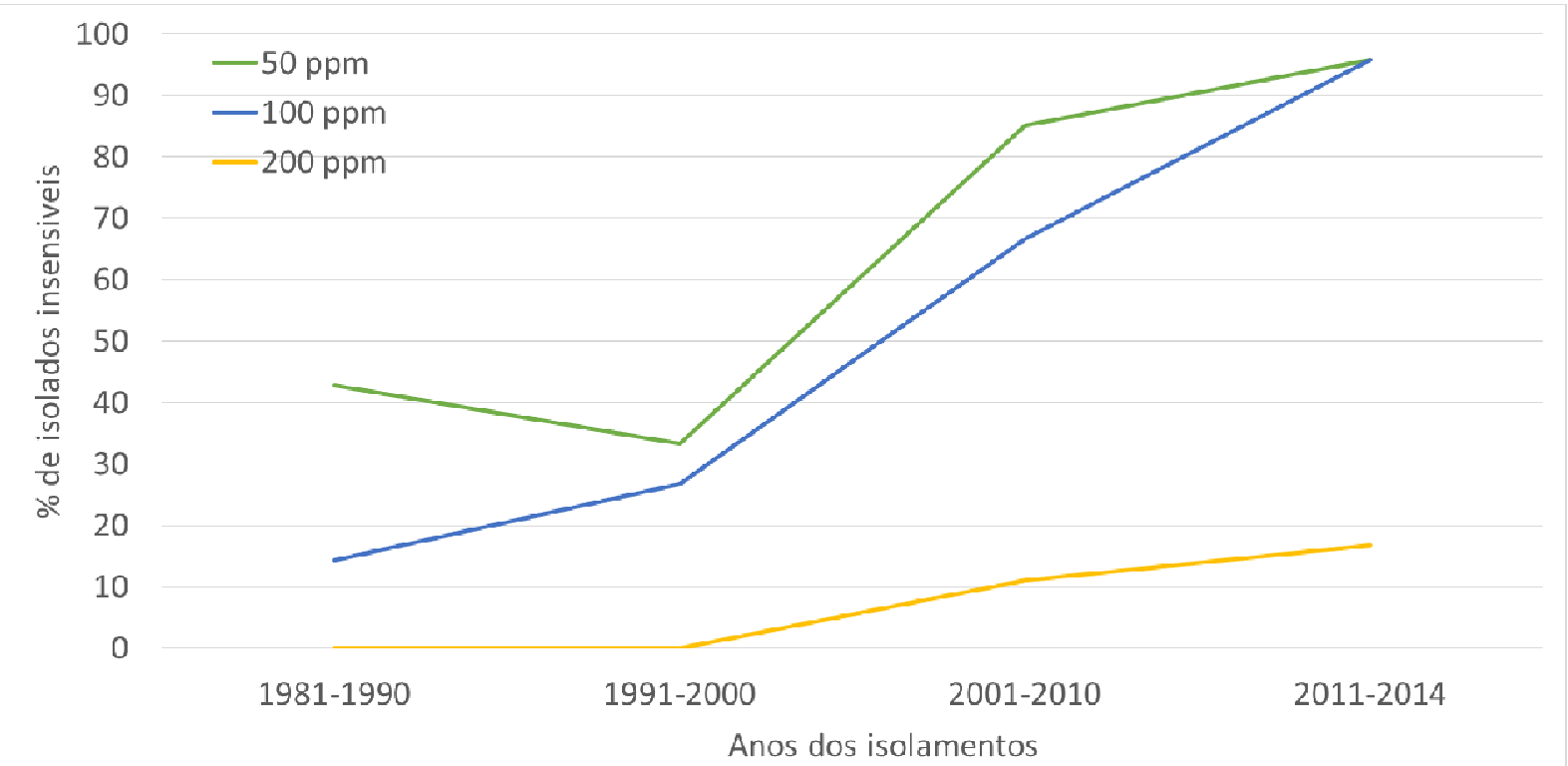

Figura 4. Porcentagem de isolados de Xanthomonas spp. insensíveis às diferentes concentrações de cobre de acordo com a época em que foi isolado. 
$\mathrm{Na}$ concentração de $50 \mu \mathrm{g} / \mathrm{mL}$ de cobre, a região com maior número de isolados insensíveis foi o Centro-Oeste com 82,76\%, seguido do Nordeste com 73,68\%, Norte com $66,67 \%$ e Sudeste com 58,82\%. Na concentração de $100 \mu \mathrm{g} / \mathrm{mL}$ de cobre, o Centro-Oeste tem $72,41 \%$ dos isolados insensíveis, o Nordeste $63,16 \%$, o Sudeste $52,94 \%$, e o Norte $50 \%$. Na mais alta concentração de $200 \mu \mathrm{g} / \mathrm{mL}$ de cobre, no Nordeste $21,05 \%$ dos isolados foram insensíveis, 10,34\% no Centro-Oeste e nenhum no Norte e Sudeste (Figura 3).

Na Figura 4 foram compiladas as porcentagens de isolados de cada década que foram insensíveis às diferentes concentrações de cobre. Entre os anos de 1981 e 1990 um baixo número de isolados foi insensível às concentrações de $50 \mu \mathrm{g} / \mathrm{mL}(42,8 \%), 100 \mu \mathrm{g} / \mathrm{mL}(14,3 \%)$ e nenhum isolado apresentou insensibilidade à concentração mais alta $(200 \mu \mathrm{g} / \mathrm{mL})$. Entre os anos de 1991 e 2000, nenhum isolado foi insensível à $200 \mu \mathrm{g} / \mathrm{mL}$ de cobre, e às concentrações de $50 \mu \mathrm{g} / \mathrm{mL}$ (33,3\% isolados insensíveis), e $100 \mu \mathrm{g} / \mathrm{mL}$ (26,67\%). Entre os anos de 2001 e 2010, 85,2\% dos isolados foram insensíveis à concentração de $50 \mu \mathrm{g} / \mathrm{mL}, 66,7 \%$ à $100 \mu \mathrm{g} / \mathrm{mL}$ e $11,1 \%$ à $200 \mu \mathrm{g} / \mathrm{mL}$. No último intervalo entre os anos de 2011 e 2014 houve um aumento para $95,8 \%$ na concentração de $50 \mu \mathrm{g} / \mathrm{mL}, 95,8 \%$ em $100 \mu \mathrm{g} / \mathrm{mL}$ e $16,7 \%$ na maior concentração, de $200 \mu \mathrm{g} / \mathrm{mL}$.

\section{DISCUSSÃO}

Analisando a proporção de isolados insensíveis à maior concentração de cobre (200 $\mu \mathrm{g} / \mathrm{mL}$ ) por estado e data do isolamento (Figura 1, 2 e 3), foi encontrado o padrão esperado, em que isolados mais novos têm maior probabilidade de apresentar insensibilidade às maiores concentrações de cobre, provavelmente devido a um maior número de gerações expostas à aplicação do princípio ativo. O número de isolados insensíveis aumentou ao longo dos anos, ocorrendo um incremento da insensibilidade, em especial, na concentração de $50 \mu \mathrm{g} / \mathrm{mL}$, com 
exceção dos anos de 1991 e 2000 em que houve uma queda no número de isolados insensíveis ao cobre na concentração mais baixa, provavelmente devido ao baixo número de isolados disponíveis para a análise nesse período. Corroborando para isso está o fato de se ter observado o aumento para os anos de 2001 a 2010 em que a porcentagem de isolados insensíveis a $50 \mu \mathrm{g} / \mathrm{mL}$ foi para $85,2 \%$. Entre os anos de 2001 a 2014 o aumento de isolados insensíveis a $200 \mu \mathrm{g} / \mathrm{mL}$ aumentou de $0 \%$ para $16,7 \%$. O uso do cobre no controle de doenças remete ao ano 1970, e um fator que não deve ser ignorado é a rápida adaptação de procariotos diante de princípios ativos usados no controle (Freitas, 2013). O uso constante e progressivo do cobre para o controle de bacterioses provavelmente levou à seleção de isolados insensíveis, nas diferentes espécies aqui estudadas. A evolução dessa insensibilidade é marcante, em especial pelo aparecimento recente de isolados com elevada resistência, sem resposta à concentração de $200 \mu \mathrm{g} / \mathrm{mL}$.

O meio de cultura CYE (casitone-yeast extract, Zevenhuizen et al., 1979) suplementado com $200 \mu \mathrm{g} / \mathrm{mL}$ de sulfato de cobre tem sido avaliado para testar a resistência do crescimento bacteriano de isolados de Xanthomonas associadas à mancha-bacteriana (Ritchie \& Dittapongpitch, 1991; Bouzar et al., 1999; Quezado-Duval et al., 2003; Pereira, 2010; Costa et al., 2012), uma vez que essa concentração está associada à perda da eficiência de controle in vivo (Aguiar et al., 2000; Carmo et al., 2001). Resistência à menor concentração de cobre, como detectada no presente trabalho, também foi observada por Sahin \& Miller (1996) e Quezado-Duval et al. (2003) em isolados de Xanthomonas provenientes do pimentão e de tomate para processamento industrial, respectivamente.

O maior uso do cobre no controle de doenças bacterianas tem como consequência esperada o aumento da insensibilidade, porém, espera-se dos produtores o aumento significativo da aplicação do princípio ativo, já que não existem alternativas de controle que possam ser usadas após o aparecimento da doença e que possua efeito curativo. 
Para a realização de testes de sensibilidade in vitro ao cobre, normalmente utilizam-se concentrações 10 vezes menores do que as recomendadas para o controle da doença no campo, segundo Andrei (2005), uma vez que in vitro, a bactéria é exposta diretamente à ação dos princípios ativos.

Ritchie \& Dittapongpitch (1991), Ward \& O'Garro (1992), Gore \& O'Garro (1999) e Aguiar et al. (2000) consideraram resistentes isolados de Xanthomonas spp. provenientes de pimentão e tomateiro aqueles que cresceram em meio de cultura contendo $200 \mu \mathrm{g} . \mathrm{mL}$ de sulfato de cobre. Desta forma os isolados aqui avaliados, apenas 7 (10\%) foram resistentes a $200 \mu \mathrm{g} / \mathrm{mL}$ de sulfato de cobre. Esse resultado pode estar relacionado a um uso mais intensivo de fungicidas cúpricos para o controle da mancha-bacteriana nas lavouras amostradas. No entanto, a constatação da existência de isolados moderadamente insensíveis $(100 \mu \mathrm{g} / \mathrm{mL})$ pode ser considerada um alerta para um uso mais racional do princípio ativo, de maneira a preservar a eficiência ao longo do tempo dessa importante ferramenta de controle.

Vários trabalhos têm mostrado a resposta de Xanthomonas spp. do tomateiro e pimentão ao sulfato de cobre in vitro. Ward \& O'Garro (1992) relataram que 64\% dos isolados de Xanthomonas spp., associadas a mancha-bacteriana do pimentão, foram resistentes ao sulfato de cobre $(200 \mu \mathrm{g} / \mathrm{mL})$. Resultados semelhantes foram obtidos por Ritchie \& Dittapongpitch (1991) e Gore \& Gorro (1999), em que, respectivamente, 63\% e $60 \%$ dos isolados de Xanthomonas spp. de pimentão foram resistentes a $200 \mu \mathrm{g} / \mathrm{mL}$ de cobre. Por sua vez, Areas (2013) avaliou a sensibilidade in vitro ao cobre de 59 isolados de $X$. euvesicatoria, sendo a maioria proveniente do estado de São Paulo. Esse Estado é o maior produtor de pimentão do país, tendo uma maior ocorrência da mancha-bacteriana devido ao volume de produção e consequentemente, uma maior aplicação de produtos a base de cobre. Esse é um fato que pode estar relacionado com os resultados encontrados pela autora, em que $80 \%$ dos isolados avaliados foram insensíveis a $200 \mu \mathrm{g} / \mathrm{mL}$. No presente estudo, apenas $10 \%$ 
dos isolados foram insensíveis a essa concentração. O tipo de meio de cultura utilizado pode ter influência nos testes in vitro (Cazorla et al., 2002), pois alguns meios de cultura como por exemplo o Nutriente ágar (NA) retém parte dos íons cobre, reduzindo a concentração do produto a que a bactéria é submetida. Dessa forma, os isolados com reação de insensibilidade na concentração de $200 \mu \mathrm{g} / \mathrm{mL}$ podem, em realidade, serem insensíveis a uma concentração inferior à que foi depositada no meio.

\section{CONCLUSÃO}

Existem isolados brasileiros de Xanthomonas euvesicatoria provenientes de lavouras de pimentão insensíveis ao cobre em níveis que potencialmente caracterizaria uma ausência de controle no campo. 


\section{REFERÊNCIAS BIBLIOGRÁFICAS}

ADASKAVEG, JAMES E.; R. B. HINE. 1985. Copper tolerance zinc sensitivity of Mexican strains of Xanthomonas campestris pv. vesicatoria, causal agent of bacterial spot of pepper. Plant Disease 69(11):993-996.

AGUIAR, L. A.; KIMURA, O.; CASTILHO, A. M.; CASTILHO, K. S. C.; RIBEIRO, R. L. D.; AKIBA, F.; CARMO, M. G. F. 2000. Resistência ao cobre em isolados nacionais de Xanthomonas campestris pv. vesicatoria de pimentão e tomateiro. Agronomia 34:78-82.

AGUIAR, L.A.; KIMURA O.; CASTILHO, A.M.C.; CASTILHO, K.S.C.; RIBEIRO, R.L.D., AKIBA, F.; CARMO, M.G.F. 2003. Efeito de formulações cúpricas e cuprorgânicas na severidade da mancha-bacteriana e na população residente de Xanthomonas campestris pv. vesicatoria em pimentão. Horticultura Brasileira, Brasília 21(1): 44-50.

ARAÚJO, E.R.; PEREIRA, R.C; FERREIRA, M.A.S.V.; QUEZADO-DUVAL, A.M.; CAFÉ-FILHO, A.C. 2012. Sensitivity of xanthomonads causing tomato bacterial spot to copper and streptomycin and in vivo infra-specific competitive ability in xanthomonas perforans resistant and sensitive to copper. Journal of Plant Pathology 94:79-87.

AGROFIT, Agrofit: Sistema de agrotóxicos fitossanitários. Disponível em: http://extranet.agricultura.gov.br/agrofit_cons/principal_agrofit_cons. Acesso 13 de fevereiro de 2014.

BUONARIO, R.; SCARPONI, L.; FERRARA, M.; SIDOTI, P.; BERTONA, A. 2002. Induction of systemic acquired resistance in pepper plants by acibenzolar-S-methyl against bacterial spot disease. Journal of Plant Pathology 108:41-49.

BUONAURIO, R.; STRAVATO, V.M.; SCORTICHINI, M. 1994. Characterization of Xanthomonas campestris pv. vesicatoria from Capsicum annuum L. in Italy. Plant Disease 78(3):296-299. 
BOUZAR, H.; JONES, J. B.; STALL, F. J.; LOUWS, R. E.; LOUWS, F. J.; SCHNEIDER, M.; RADEMAKER, J. L. W, BRUJIN, D. E.; JACKSON, L. E. 1999. Multiphasic analysis of Xanthomonads causing bacterial spot disease on tomato and pepper in the Caribbean and Central America: evidence for common lineages within and between countries. Phytopathology 89:328-335.

CARMO, M.G.F.; MACAGNAN, D.; CARVALHO, A.D. 2001. Progresso da manchabacteriana do pimentão a partir de diferentes níveis iniciais de inóculo e do emprego ou não do controle com oxicloreto de cobre. Horticultura Brasileira, Brasília 19(3):210-215.

CASTRO, V. L. S. S. 2009. Uso de misturas de agrotóxicos na agricultura e suas implicações toxicológicas na saúde. Jornal Sociedade Brasileira de Ecotoxicologia 4:1-3.

CAZORLA, F. M.; ARREBOLA, E.; SESMA, A.; PÉREZGARCÍA, A.; CODINA, J. C.; MURILlO, J.; VICENTE, A. 2002. Copper resistance in Peseudomonas syringae strains isolated from mango is encoded mainly by plasmids. Phytopathology 92:909-916.

COSTA, J. R.; ARAÚJO, E. R.; BECKER, W. F.; FERREIRA, M. A. S.V QUEZADODUVAL, A.M. 2012. Ocorrência e caracterização do complexo de espécies causadoras da mancha-bacteriana do tomateiro no Alto Vale do Rio do Peixe, SC. Tropical Plant Pathology $37: 149-154$.

COSTA, R. A.; RODRIGUES, R.; SUDRÉ, C. P. 2002. Resistência genética à manchabacteriana em genótipos de pimentão. Horticultura Brasileira 20(1):86-89.

FREITAS, E.C. 2013. Caracterização molecular de proteínas envolvidas no mecanismo de homeostase de cobre em Xanthomonas citri subsp. Citri. 163p. Tese (doutorado) Universidade Estadual Paulista.

GORE, J. P.; O'GARRO, L. W. 1999. Reaction of Xanthomonas campestris from Bell Pepper and Tomato in Barbados to Chemical Control Agents. Journal Phytopathology 147:397-402. 
KIZHEVA, Y.; VANCHEVA, T.; HRISTOVA, P.; STOYANOVA, M.; STOJANOVSKA, M.; MONCHEVA, P.; BOGATZEVSKA, N. 2013. Identification of Xanthomonas strains from tomato and pepper and their sensitivity to antibiotics and copper. Agricultural Academy $19: 80-82$.

MARCO, G. M.; STALL, R. E. 1983. Control of bacterial spot of pepper initiated by strains of Xanthomonas campestris pv. vesicatoria that differ in sensitivity to copper. Plant Disease 67(7):779-781.

MARINGONI, A.C.; KIMATI, H. 1987a. Caracterização patogênica e hidrolise de amido em Xanthomonas campestris pv. vesicatoria de pimentão e tomateiro. Fitopatologia Brasileira 12:325-333.

MARINGONI, A.C.; KIMATI, H. 1987b. Diferenciação sorológica entre isolados de Xanthomonas campestris pv. vesicatoria de pimentão e tomateiro. Fitopatologia Brasileira 12:322-324.

MARINGONI, A.C.; KIMATI, H. 1987c. Sensibilidade in vitro de Xanthomonas campestris pv. vesicatoria (Doidge) Dye de pimentão e de tometeiro a drogas. Summa Phytopathologica 13:160-171.

MARTIN, H. L.; HAMILTON V. A. 2004. Copper tolerance in Australian populations of Xanthomonas campestris pv. vesicatoria contributes to poor field control of bacterial spot of pepper. Plant Disease 88:921-924.

MINSAVAGE, G. V.; DAHLBECK, D.; WHALEN, V.; KEARNEY,B.; BONAS, U.; STASKAWICZ, B. J.; STALL , R. E. 1990. Gene-for-gene relationships specifying disease resistance in Xanthomonas campestris pv. vesicatoria pepper interactions. Molecular Plant Microbe Interactions 3(1):41-47.

O'GARRO, L.W. 1998. Bacterial spot of tomato and pepper on four East Caribbean islands: races, their abundance, distribution, aggressiveness, and prospects for control. Plant Disease 82(8):864-870. 
PEREIRA, R. DA C. 2010. Ocorrência, caracterização e identificação das espécies de Xanthomonas causadoras de mancha-bacteriana em tomate para mesa no Brasil. Dissertação (Mestrado em Fitopatologia) Universidade de Brasília, Brasília, 77p.

QUEZADO-DUVAL, A. M.; GAZZOTO FILHO, A.; LEITE JÚNIOR, R. P.; CAMARGO L. E. A. 2003. Sensibilidade a cobre, estreptomicina e oxitetraciclina em Xanthomonas spp. associadas à mancha-bacteriana do tomate para processamento industrial. Horticultura Brasileira 21:672-677.

QUEZADO-SOARES, A.M.; LOPES, C.A. 1999. Controle químico da mancha-bacteriana em tomateiro para processamento industrial. Summa Phytopathologica 25:21.

RITCHIE, D. F.; DITTAPONGPITCH, V. 1991. Copper-and streptomycin-resistant strains and host differentiated races of Xanthomonas campestris pv. vesicatoria in North Carolina. Plant Disease 75(7):733-736.

SAHIN, F.; MILLER, S. A. 1996. Characterization of Ohio strains of Xanthomonas campestris pv. vesicatoria, causal agent of bacterial spot of pepper. Plant Disease 80(7): 773778.

STALL, R. E.; JONES, J. B.; MINSAVAGE, G. V. 2009. Durability of resistance in tomato and pepper to xanthomonads causing bacterial spot. Annual Review of Phytopathology, Palo Alto 47:265-284.

STALL, R. E.; LOSCHKE, D. C.; JONES, J. B. 1986. Linkage of copper resistence and avirulence loci on a self-transmissible plasmid in Xanthomonas campestris pv. campestris. Phytopathology 76(2):240-242.

TETAZ, T. J.; LUKE, R. K. 1983. Plasmid-controlled resistance to copper in Escherichia coli. Journal of Bacteriology 154(3):1263-1268.

WARD, H.P.; O' GARRO, L.W. 1992. Bacterial spot of pepper and tomato in Barbados. Plant Disease 76:1046-1048. 